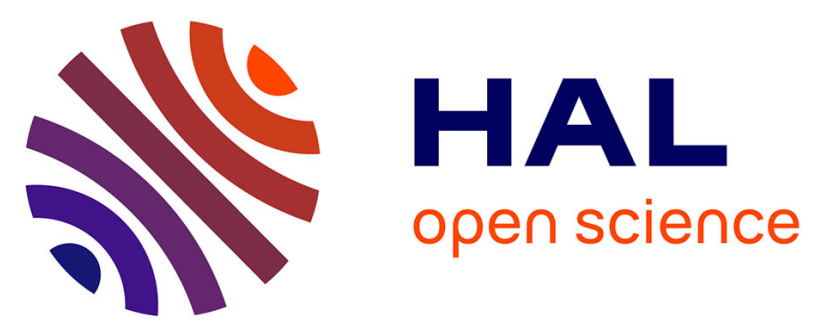

\title{
Dipolar NLO Chromophores Bearing Diazine Rings as $\pi$-Conjugated Linkers
}

Milan Klikar, Pascal Le Poul, Aleš Růžička, Oldřich Pytela, A. Barsella, Kokou Dorkenoo, Françoise Robin-Le Guen, Filip Bureš, Sylvain Achelle

\section{- To cite this version:}

Milan Klikar, Pascal Le Poul, Aleš Růžička, Oldřich Pytela, A. Barsella, et al.. Dipolar NLO Chromophores Bearing Diazine Rings as $\pi$-Conjugated Linkers. Journal of Organic Chemistry, 2017, 82 (18), pp.9435-9451. 10.1021/acs.joc.7b01442 . hal-01617949

HAL Id: hal-01617949

https://hal-univ-rennes1.archives-ouvertes.fr/hal-01617949

Submitted on 19 Oct 2017

HAL is a multi-disciplinary open access archive for the deposit and dissemination of scientific research documents, whether they are published or not. The documents may come from teaching and research institutions in France or abroad, or from public or private research centers.
L'archive ouverte pluridisciplinaire HAL, est destinée au dépôt et à la diffusion de documents scientifiques de niveau recherche, publiés ou non, émanant des établissements d'enseignement et de recherche français ou étrangers, des laboratoires publics ou privés. 


\title{
Dipolar NLO chromophores bearing diazine rings as $\pi$-conjugated linkers
}

\author{
Milan Klikar, ${ }^{\dagger}{ }^{\ddagger}$ Pascal le Poul, ${ }^{\dagger}$ Aleš Růžička, ${ }^{\ddagger}$ Oldřich Pytela,${ }^{\ddagger}$ Alberto Barsella, ${ }^{\S}$ Kokou D. \\ Dorkenoo ${ }^{\S}$ Françoise Robin-le Guen, ${ }^{\dagger}$ Filip Bureš, ${ }^{*},{ }^{\star}$ and Sylvain Achelle ${ }^{*}$,
}

${ }^{\dagger}$ Institut des Sciences Chimiques de Rennes UMR CNRS 6226, IUT de Lannion, Université de Rennes 1, rue Edouard Branly, BP 30219, F22302 Lannion Cedex, France. ${ }^{\ddagger}$ Institute of Organic Chemistry and Technology, Faculty of Chemical Technology, University of Pardubice, Studentská 573, Pardubice, 53210, Czech Republic. \$ Department of General and Inorganic Chemistry, Faculty of Chemical Technology, University of Pardubice, Studentská 573, Pardubice, 53210, Czech Republic. ${ }^{\S}$ Département d'Optique ultra-rapide et Nanophotonique, IPCMSCNRS, 23 Rue du Loess, BP 43, 67034 Strasbourg Cedex 2, France.

Corresponding authors: *E-mails: sylvain.achelle@univ-rennes1.fr; filip.bures@upce.cz

\section{Synopsis TOC}

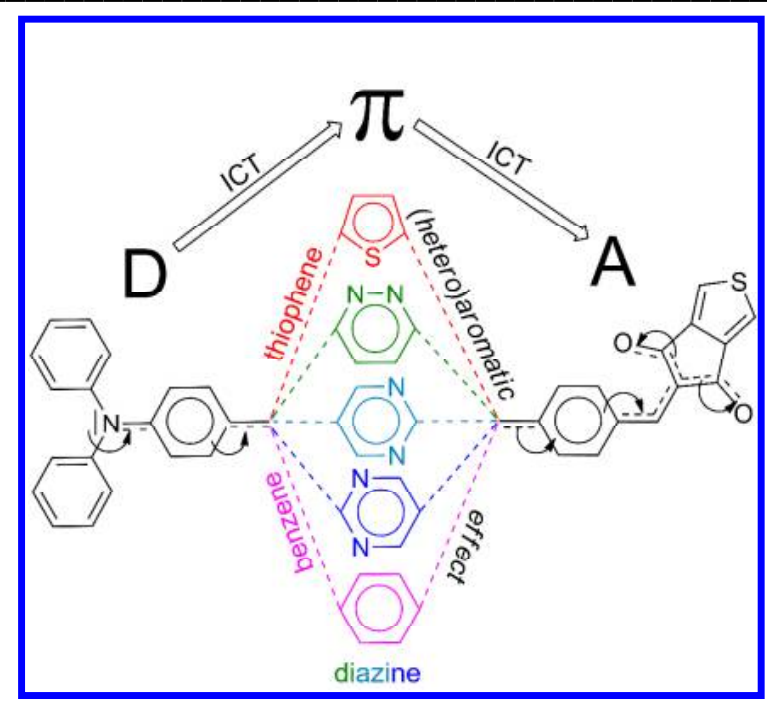




\begin{abstract}
The synthesis of a series of push-pull derivatives bearing triphenylamine electron-donating group, cyclopenta[c]thiophen-4,6-dione electron acceptor and various $\pi$-linkers including (hetero)aromatic fragments is reported. All target chromophores with systematically varied $\pi$-linker structure were further investigated by electrochemistry, absorption measurements and EFISH experiments in conjunction with DFT calculations. Based on electrochemical and photophysical measurements, when a polarizable 2,5-thienylene moiety is embedded into the chromophore $\pi$-backbone the highest intramolecular charge transfer (ICT) is observed. Benzene, pyrimidine and pyridazine derivatives exhibit lower polarizability and extent of the ICT across these $\pi$-linkers. The elongation of the $\pi$-conjugated system via additional ethenylene linker results in a significant reduction of the HOMO-LUMO gap and an enhancement of the NLO response. Whereas it does not significantly influence electrochemical and linear optical properties, the orientation of the pyrimidine ring seems to be a key parameter on the $\mu \beta$ value due to significant variation of the dipolar moment $(\mu)$ value. In $\mathbf{2 a}$ and $\mathbf{2} \mathbf{c}$ is pyrimidine oriented to behave as an acceptor and thus generate dipolar molecule with $\mu$ above $5 \mathrm{D}$, whereas in $\mathbf{2 b}$ and $\mathbf{2 d}$ is ground state dipole moment significantly reduced. This study seems to indicate a high aromaticity of pyrimidine and pyridazine derivatives, close to the benzene analogues and significantly higher than thiophene analogues.

\section{Introduction}

During the past two decades, there has been a great interest in the design of dipolar push-pull chromophores bearing an electron donating (D) and an electron-withdrawing group (A) separated by a $\pi$-conjugated spacer (D- $\pi$-A design). The push-pull structure leads to an efficient intramolecular charge transfer (ICT) from the donor to the acceptor part and generation of a molecular dipole. The ICT can easily be illustrated by two limiting resonance forms (neutral and zwitterionic arrangement). ${ }^{1}$ Dipolar chromophores are known for their 
interesting electro-optic activities and this design has been efficiently used in the conception of fluorescent probes, ${ }^{2}$ chromophores for dyes sensitized solar cells (DSSC), ${ }^{3}$ two-photon absorption dyes ${ }^{4}$ and $2^{\text {nd }}$ order nonlinear optic (NLO) chromophores. ${ }^{5}$ Second-order NLO materials have found applications in blue/green laser obtained from red sources through frequency doubling, such as second-harmonic generation or terahertz wave generation. ${ }^{6}$

The properties of dipolar chromophores can easily be tuned by modification of the donor/acceptor couple, ${ }^{7}$ however this strategy inclines to reach its limit. The optimization of $\pi$-conjugated bridge is also a key parameter that affects the ICT. $^{8}$ Experimental and theoretical studies have confirmed that the aromaticity of the $\pi$-conjugated bridge is directed towards the ICT. In this context, it has been shown that replacement of a benzene ring by a less aromatic and easily polarizable heterocycles such as thiophene, pyrrole or furan imparts an enhanced ICT in the chromophore. ${ }^{9}$

Diazines are six-membered heterocycles with two nitrogen atoms. Depending on the position of the nitrogen atoms, pyridazine (1,2-diazine), pyrimidine (1,3-diazine) and pyrazine (1,4-diazine) can be distinguished. The diazine rings have been extensively used as electronwithdrawing part of push-pull structures. ${ }^{10}$ Only few examples of incorporating diazine rings as $\pi$-linker in push-pull systems have been described so far, all of them focused on pyrimidine systems for photovoltaic application. ${ }^{11}$ It has been shown that the replacement of 1,4-phenylene $\pi$-spacer by a pyrimidine ring leads to higher light harvesting efficiency. ${ }^{11 \mathrm{a}-\mathrm{b}} \mathrm{It}$ is generally admitted that the aromaticity decreases with increasing number of embedded nitrogen atoms within the ring. However, the available reports on the aromaticity and stability of diazines are contradictory with no consistent conclusions. ${ }^{12}$ Ortíz et al. have studied experimentally and theoretically aminopyrimidine-based donor-acceptor compounds; they have shown that a subtle trade-off between aromaticity and push-pull effect explains their electronic properties. ${ }^{13}$ Alonso and co-workers have calculated the aromaticity of pyrimidine 
and their benzene analogues using various descriptors. ${ }^{12 a}$ They have shown that pyrimidine is less aromatic than benzene and, in contradiction to benzene, the appended substituents decrease its aromaticity. On the contrary, Wang et al. claimed that diazine aromaticity is similar to benzene and the observed lower relative energy of pyridazine isomer is due to a weak N-N bond rather than its reduced aromaticity. ${ }^{12 \mathrm{e}}$

In order to explore diazines as $\pi$-conjugated linkers in push-pull molecules, we have designed a series of seven dipolar push-pull chromophores 1-2 (Chart 1). These molecules possess 2,5-disubstituted pyrimidine or 3,6-disubstituted pyridazine moieties as a part of the $\pi$-system, diphenylamino donor, and cyclopenta[c]thiophen-4,6-dione electron acceptor (ThDione). As a structural analogue to indan-1,3-dione, ThDione has recently been prepared in our group and proved to be very powerful electron-withdrawing group. ${ }^{14}$ The properties of diazine-based chromophores 1-2 will be critically compared with 1,4-phenylene and 2,5-thienylene analogues $\mathbf{3}$ (Chart 2). Additional chromophores $\mathbf{4 a - b}$ are model compounds to study effect of the $\pi$-linker length (Chart 2). Hence, we report herein their synthesis, thermal, electrochemical, and (non)linear optical properties completed with the DFT calculations. 
1

2

3

4

5

6
7

8

9

10

11

12

13

14

15

16

17

18

19

20

21

22

23

24

25

26

27

28

29

30

31

32

33

34

35

36

37

38

39

40

41

42

43

44

45

46

47

48

49

50

51

52

53

54

55

56

57

58

59

60

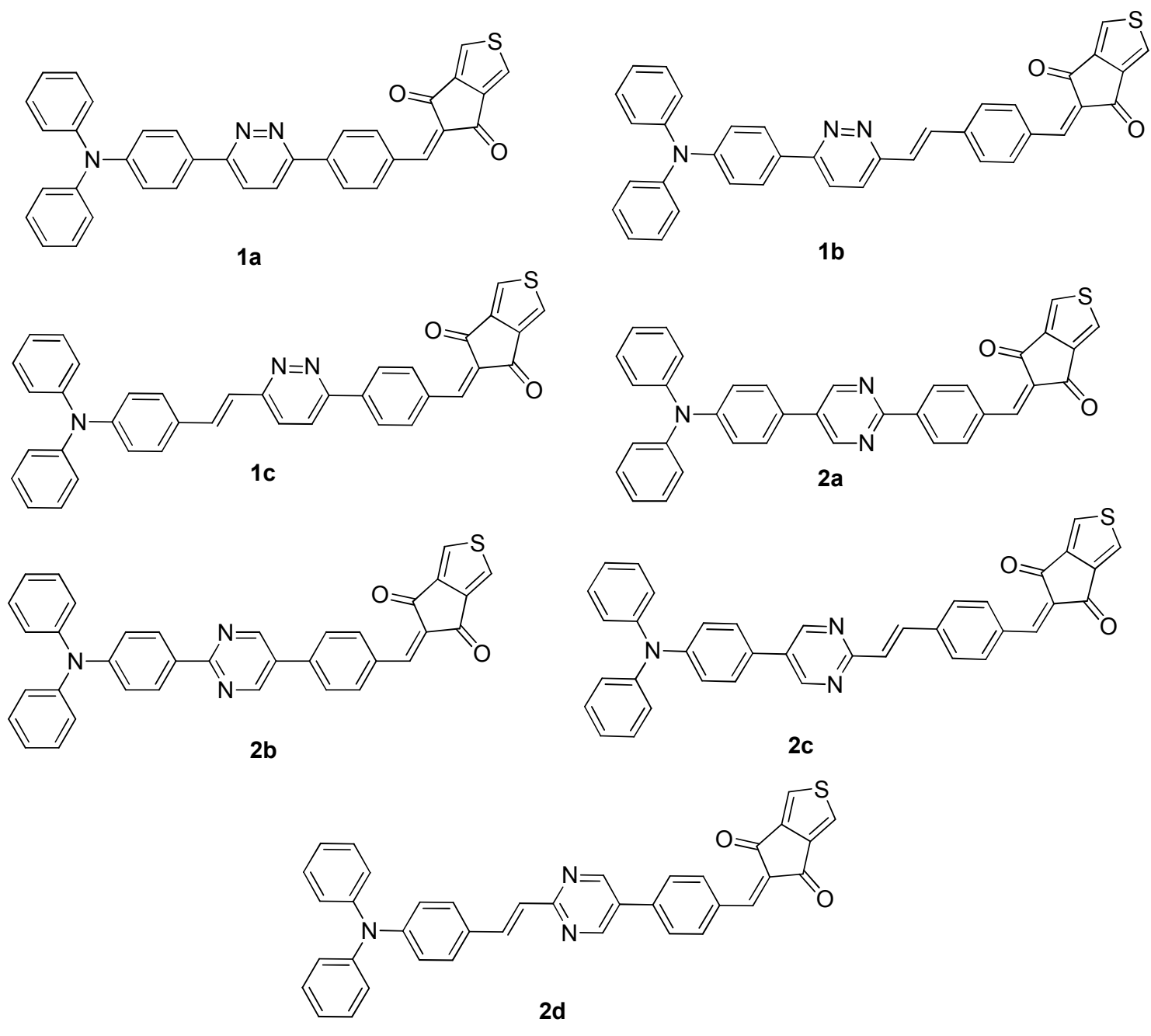

\section{Chart 1}




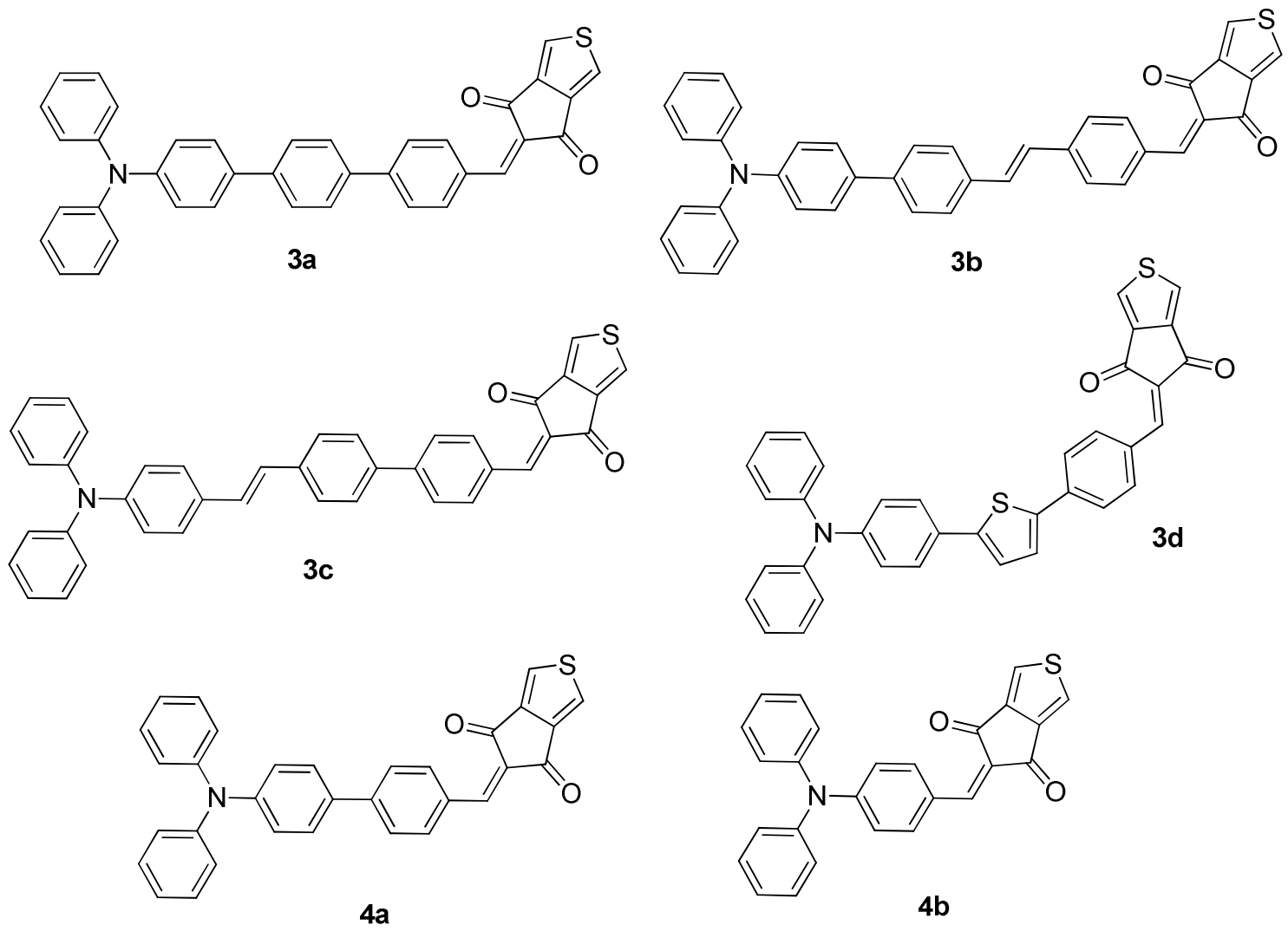

\section{Chart 2}

\section{Results and discussion}

\section{Synthesis}

The chromophore $\mathbf{4 b}$ was synthesized by direct Knoevenagel condensation between commercial available 4-( $N, N$-diphenylamino)benzaldehyde $\mathbf{8 b}$ and ThDione $\mathbf{1 1}$ (Scheme 1) in the yield of $71 \%$. Biphenyl aldehyde 8a was prepared from 4-bromotriphenylamine 9 and 4-formylphenylboronic acid pinacol ester $\mathbf{1 0}$ via Suzuki-Miyaura cross-coupling reaction. Subsequent Knoevenagel condensation with ThDione $\mathbf{1 1}$ gave target chromophore 4a (Scheme 1). 


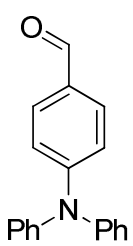

$8 b$

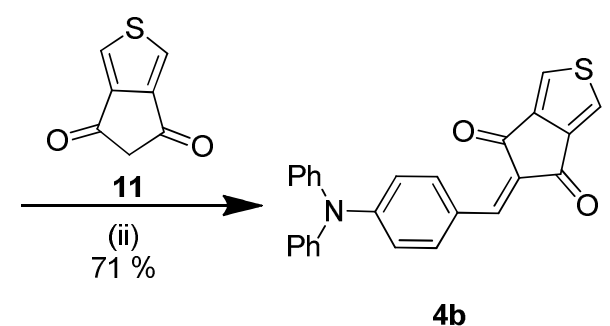

4b

Key: (i) $\mathrm{Pd}\left(\mathrm{PPh}_{3}\right)_{4}, \mathrm{Na}_{2} \mathrm{CO}_{3}$, toluene/EtOH/H $\mathrm{H}_{2} \mathrm{O}, \Delta$, overnight; (ii) piperidine (cat.), $\mathrm{CH}_{2} \mathrm{Cl}_{2}, 40^{\circ} \mathrm{C}, 30 \mathrm{~min}$.

Scheme 1. Synthesis of $\mathbf{4 a - b}$.

The chromophores 1a, 2a-b, 3a and 3d were obtained from the corresponding dihalogeno derivatives 13, 16, 19, and 21 via two successive Suzuki-Miyaura cross coupling reactions followed by a Knoevenagel condensation reaction with ThDione 11 (Schemes 1-4). Due to a $\pi$-electron deficient character of both chloro-diazines 13 and 16, the cross-coupling reactions can smoothly be carried out without the use of special and expensive Pd-precatalysts and ligands. ${ }^{15}$ Commercially available 3,6-dichoropyridazine 13 underwent mono cross-coupling reaction with 4-formylphenyl-boronic acid $\mathbf{1 2}$ to intermediate 14 (Scheme 2). A second Suzuki-Miyaura reaction with 4-diphenylaminophenylboronic acid $\mathbf{1 5}$ afforded aldehyde 5a that upon treatment with 11 provided target chromophore 1a. The synthetic route towards pyrimidine derivatives $\mathbf{2 a - b}$ starts from 5-bromo-2-chloropyrimidine 16, which underwent regioselective Suzuki-Miyaura reaction ${ }^{16}$ with $\mathbf{1 2}$ and $\mathbf{1 5}$ to monocoupled intermediates $\mathbf{1 7}$ and 18 (Scheme 3). Their final Knoevenagel condensation with 11 afforded chromophores 2a-b. Starting from 1-bromo-4-iodobenzene 19 and 2,5-dibromothiophene 21, a similar reaction sequence was employed to obtain 3a and 3d, respectively (Schemes 4-5). 
<smiles>COc1ccc(C=O)cc1</smiles>

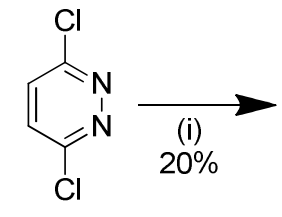

12<smiles>Cc1ccc(-c2ccc(C=O)cc2)nn1</smiles>

14

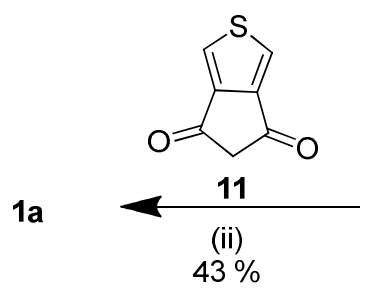

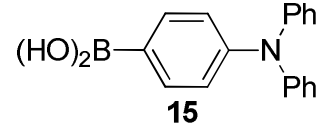

(i) $65 \%$

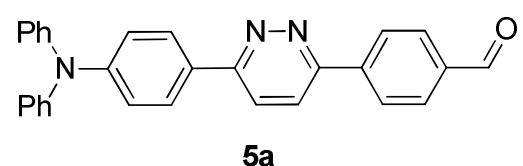

Key: (i) $\mathrm{Pd}\left(\mathrm{PPh}_{3}\right)_{4}, \mathrm{Na}_{2} \mathrm{CO}_{3}$, toluene/EtOH/ $\mathrm{H}_{2} \mathrm{O}, \Delta$, overnight; (ii) piperidine (cat.), $\mathrm{CH}_{2} \mathrm{Cl}_{2}, 40{ }^{\circ} \mathrm{C}, 30 \mathrm{~min}$.

Scheme 2. Synthesis of 1a.

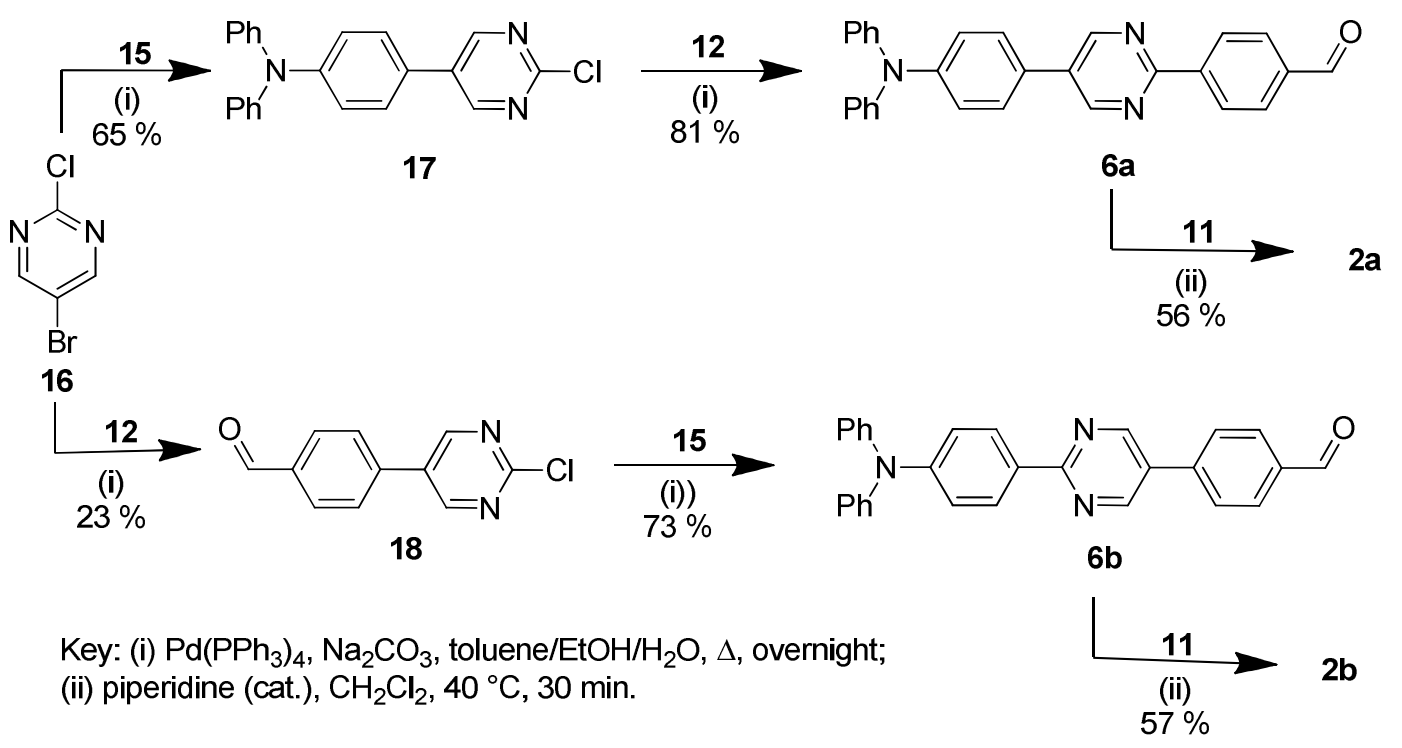

Scheme 3. Synthesis of $\mathbf{2 a - b}$.

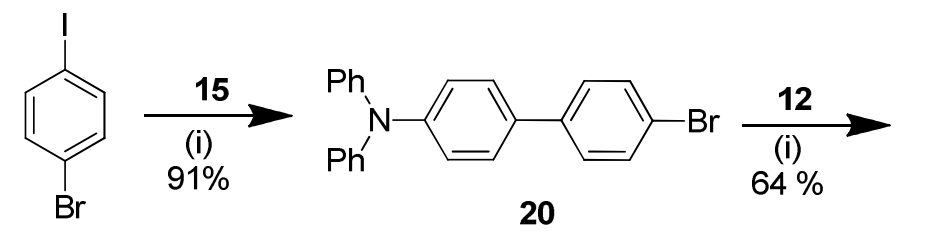

19

Key: (i) $\mathrm{Pd}\left(\mathrm{PPh}_{3}\right)_{4}, \mathrm{Na}_{2} \mathrm{CO}_{3}$, toluene/EtOH/ $\mathrm{H}_{2} \mathrm{O}, \Delta$, overnight; (ii) piperidine (cat.), $\mathrm{CH}_{2} \mathrm{Cl}_{2}, 40^{\circ} \mathrm{C}, 30 \mathrm{~min}$.<smiles>O=Cc1ccc(-c2ccc(-c3ccc(N(c4ccccc4)c4ccccc4)cc3)cc2)cc1</smiles>

$7 \mathbf{a}$

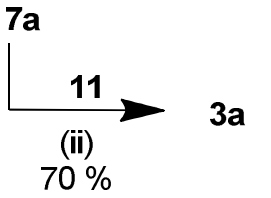

Scheme 4. Synthesis of 3a. 
Scheme 5. Synthesis of 3d.

Starting from commercially available 3-chloro-6-methylpyridazine 23, a Suzuki-Miyaura cross-coupling with $\mathbf{1 2}$ or $\mathbf{1 5}$ afforded the intermediates $\mathbf{2 4}$ and $\mathbf{2 6}$ with good yields (Scheme 6). Protection of the aldehyde function in $\mathbf{2 6}$ led to acetal $\mathbf{2 7}$. Aldehydes $\mathbf{5 b} \mathbf{b} \mathbf{c}$ were obtained exclusively as $E$ isomers by condensation reaction between $\mathbf{2 4}$ and $\mathbf{2 7}$, bearing active methyl group, and aldehydes $\mathbf{2 5}$ and $\mathbf{2 8}$ using dimsyl potassium according to a reported procedure $^{10 \mathrm{~d}, 17}$ and followed by acidic cleavage of the acetal protecting group. Target chromophores $\mathbf{1 b}-\mathbf{c}$ were obtained by Knoevenagel condensation of $\mathbf{5 b}-\mathbf{c}$ with ThDione $\mathbf{1 1}$. 

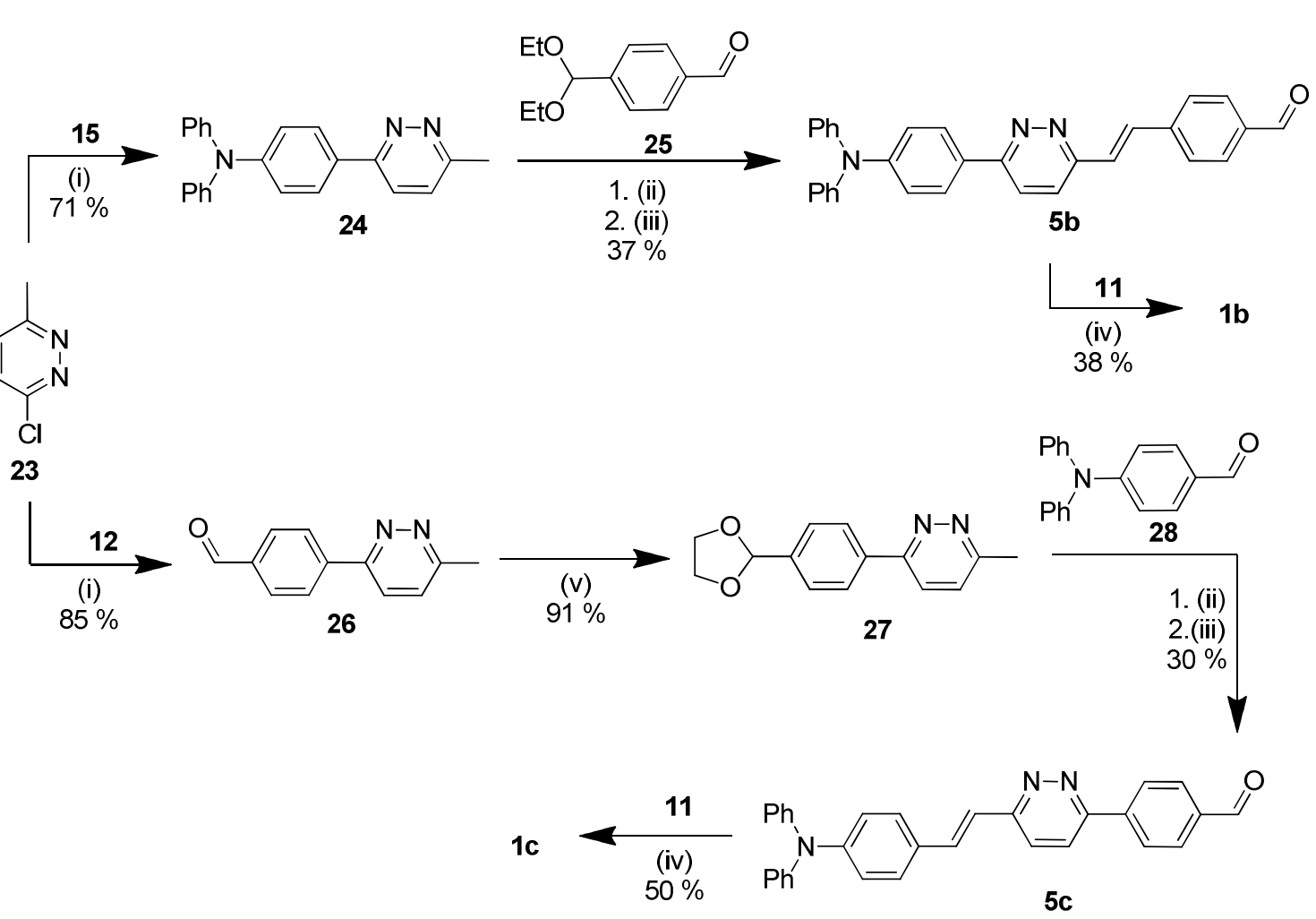

Key: (i) $\mathrm{Pd}\left(\mathrm{PPh}_{3}\right)_{4}, \quad \mathrm{Na}_{2} \mathrm{CO}_{3}$, toluene/EtOH/ $/ \mathrm{H}_{2} \mathrm{O}, \Delta$, overnight; (ii) $\mathrm{KOH}$, DMSO, rt, overnight; (iii) $\mathrm{HCl}$, acetone, $40{ }^{\circ} \mathrm{C}, 1 \mathrm{~h}$; (iv) piperidine (cat.), $\mathrm{CH}_{2} \mathrm{Cl}_{2}, 40^{\circ} \mathrm{C}, 30 \mathrm{~min}$; (v) ethylene glycol, $\mathrm{TsOH}$ (cat.), toluene, $\Delta, 16 \mathrm{~h}$.

Scheme 6. Synthesis of $\mathbf{1 b}-\mathbf{c}$.

Starting from 5-bromo-2-methylpyrimidine 29, target chromophores $\mathbf{2 c - d}$ were obtained in a similar way (Scheme 7). 
Key: (i) $\mathrm{Pd}\left(\mathrm{PPh}_{3}\right)_{4}, \mathrm{Na}_{2} \mathrm{CO}_{3}$, toluene/EtOH/ $/ \mathrm{H}_{2} \mathrm{O}, \Delta$, overnight; (ii) $\mathrm{KOH}, \mathrm{DMSO}$, rt, overnight; (iii) $\mathrm{HCl}$, acetone, $40^{\circ} \mathrm{C}, 1 \mathrm{~h}$; (iv) piperidine (cat.), $\mathrm{CH}_{2} \mathrm{Cl}_{2}, 40^{\circ} \mathrm{C}, 30 \mathrm{~min}$; (v) ethylene glycol, $\mathrm{TsOH}$ (cat.), toluene, $\Delta, 16 h$.

Scheme 7. Synthesis of $\mathbf{2 c - d}$.

Chromophores 3b-c were obtained in a four step synthesis starting from $\mathbf{3 3}$ (Scheme 8). The first step is an Arbuzov reaction leading to phosphonate 34. The second step, affording the intermediates $\mathbf{3 5}$ and $\mathbf{3 6}$ exclusively as $E$ isomers, involved the Horner-Wadsworth-Emmons reaction with the aldehydes $\mathbf{2 5}$ and $\mathbf{2 8}$ and subsequent cleavage of the acetal to aldehyde in 35. Suzuki-Miyaura cross-coupling reactions of $\mathbf{3 5}$ and $\mathbf{3 6}$ with boronic acids $\mathbf{1 5}$ and $\mathbf{1 2}$ afforded aldehydes $\mathbf{7 b}-\mathbf{c}$ that underwent final Knoevenagel condensation with ThDione $\mathbf{1 1 .}$ 

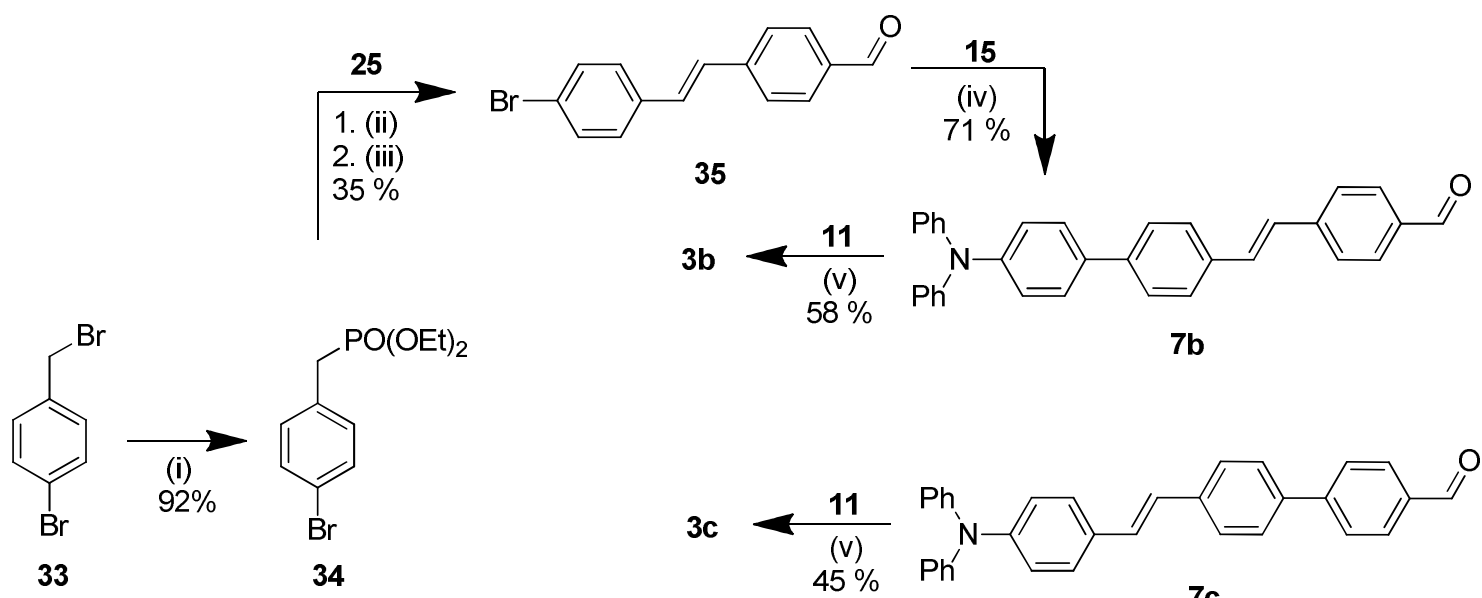

$7 \mathbf{b}$
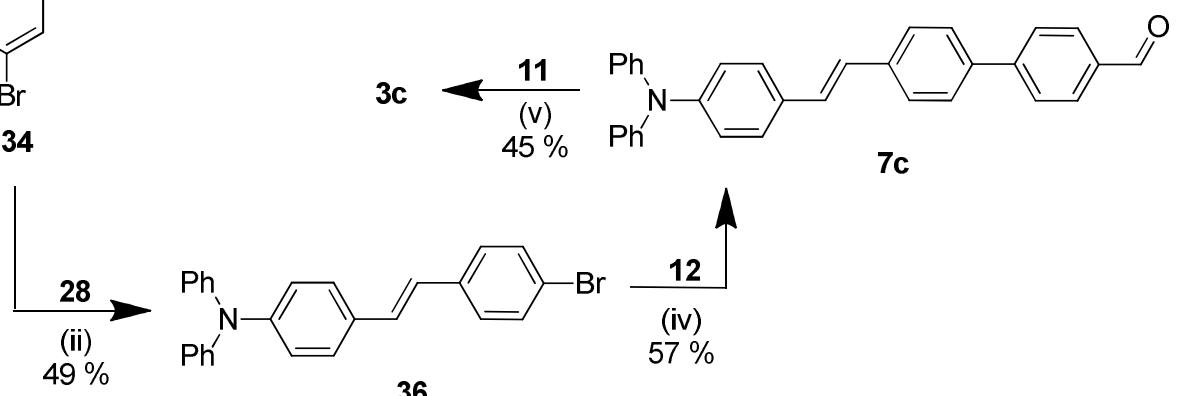

Key: (i) $\mathrm{P}(\mathrm{OEt})_{3}, 160^{\circ} \mathrm{C}, 16 \mathrm{~h}$; (ii) $\mathrm{NaH}$, toluene, $0^{\circ} \mathrm{C} \rightarrow \Delta$, $16 \mathrm{~h}$; (iii) $\mathrm{HCl}$, acetone, $40^{\circ} \mathrm{C}$, $1 \mathrm{~h}$; (iv) $\mathrm{Pd}\left(\mathrm{PPh}_{3}\right)_{4}$, $\mathrm{Na}_{2} \mathrm{CO}_{3}$, toluene/EtOH/H $\mathrm{H}_{2} \mathrm{O}, \Delta$, overnight; (v) piperidine (cat.), $\mathrm{CH}_{2} \mathrm{Cl}_{2}, 40^{\circ} \mathrm{C}, 30 \mathrm{~min}$.

Scheme 8. Synthesis of $\mathbf{3 b}-\mathbf{c}$.

All new chromophores 1-4 exhibited good solubility in organic solvents, especially in chlorinated ones. The IR, ${ }^{1} \mathrm{H}$ and ${ }^{13} \mathrm{C}$ NMR and HRMS data were consistent with the expected structures. For molecules with a vinylene linker, the ${ }^{3} J(\mathrm{H}, \mathrm{H})$ coupling constant of $\sim 16 \mathrm{~Hz}$ of the vinylic protons clearly support the selective formation of $E$-configured double bonds.

\section{X-Ray analysis}

Only chromophore 3d provided crystals suitable for X-ray analysis by slow diffusion of hexane into its dichloromethane solution. The remaining chromophores proved difficult to crystalize as single crystals. The plot shown in Figure 1 confirms the proposed molecular structure of $\mathbf{3 d}$ as well as its arrangement in the solid state. Its structure is composed of nearly linear $\pi$-conjugated path between the triphenylamine donor and ThDione acceptor, which is documented by the largest interplanar angle found within the molecule of $16.3(3)^{\circ}$. This linear arrangement allows efficient overlap of $\pi$-electrons and facilitates ICT over the whole 
$\pi$-conjugated system. In contrast to coplanar arrangement of the acceptor, phenyl rings of the amino donor adopt propeller shaped structure, typical for triarylamines. ${ }^{18}$ Aromaticity of the $\pi$-linker in $\mathbf{3 d}$ can be evaluated by calculating bond-length alternation (BLA) within the phenylene and thienylene particular subunits. The BLA, expressed as quinoid character $(\delta r)^{19,8 \mathrm{a}}$ or Bird index $\left(I_{6} / I_{5}\right),{ }^{20}$ helps to assess the extent of the ICT over the given $\pi$-system. In unsubstituted benzene, $\delta r$ equals 0 , in a fully quinoid ring, $\delta r$ would be $0.1 \AA$. The Bird indexes $I_{6}$ and $I_{5}$ of benzene and thiophene are 100 and 66, respectively. The calculated values of the 1,4-phenylene moiety within the triphenylamino donor are $\delta r=0.006 \AA$ and $I_{6}=94.9$, whereas the 1,4-phenylene ring close to the ThDione has $\delta r=0.027$ and $I_{6}=87.6$. Central 2,5-thienylene moiety possess Bird index $I_{5}$ equal to 63.8 . These values imply that all three moieties partially loss aromaticity and adopt quinoid character. Especially the phenylene ring close to the ThDione is significantly polarized compared to unsubstituted benzene as well as the second one. However, the thiophene can be polarized even further with $I_{5}$ up to 58 , for instance in T-shaped chromophores. ${ }^{21}$ The supramolecular arrangement of $\mathbf{3 d}$ reveals pairs of molecules interconnected by $\pi-\pi$ stacking interactions separated by 3.208(3) . Dichloromethane molecules are accommodated inside the cavities made between two diphenylamine parts of neighboring molecules.

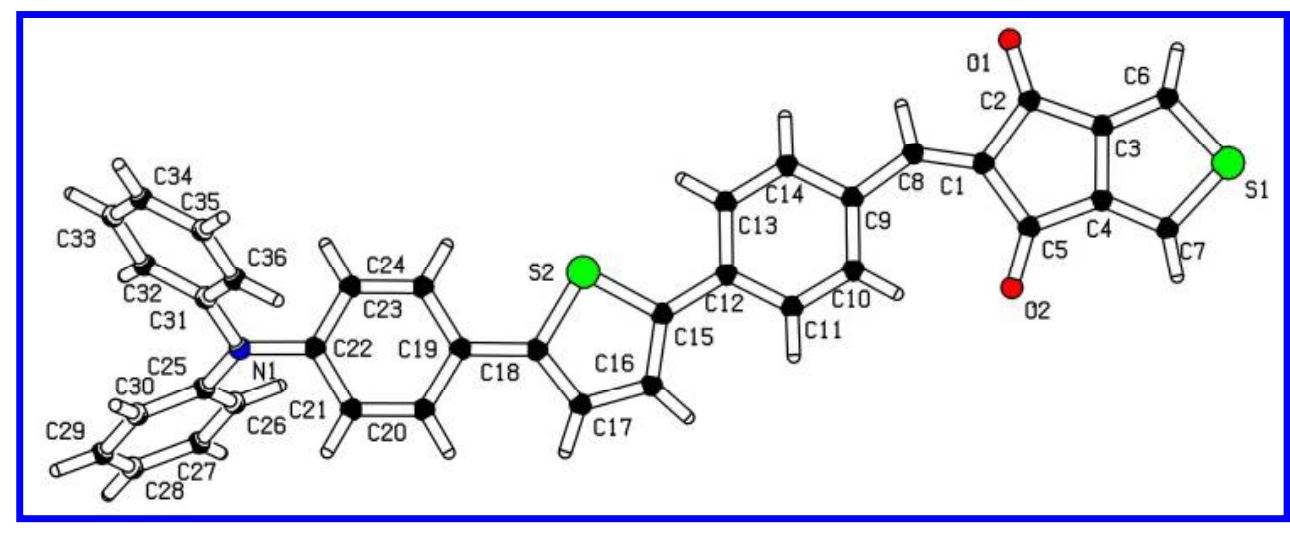

Figure 1. X-ray molecular representation of chromophore 3d (150 K, R = 0.05, CCDC 1549497). Molecule of DCM omitted for clarity. 


\section{Thermal analysis}

Thermal behaviour of compounds 1-4 was studied by differential scanning calorimetry (DSC). Figure 2 shows thermograms of representative compounds $\mathbf{1 b}, \mathbf{2 c}$ and $\mathbf{3 b}$, Table 1 lists all measured melting points $\left(T_{\mathrm{m}}\right)$ and temperatures of thermal decompositions $\left(T_{\mathrm{d}}\right)$. The measured melting points range from 206 to $302{ }^{\circ} \mathrm{C}$. The temperature of decomposition was estimated within the range of $270-330^{\circ} \mathrm{C}$.

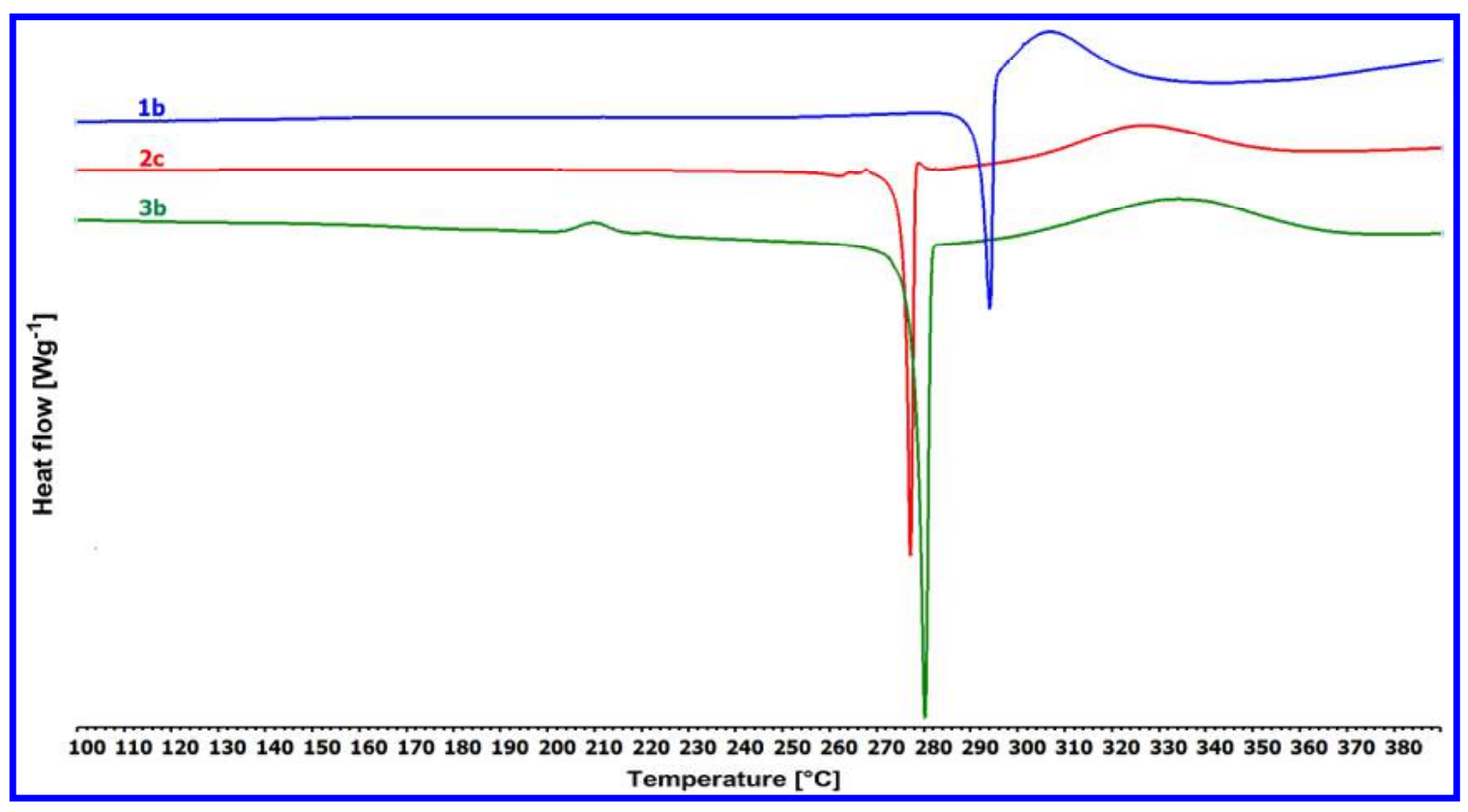

Figure 2. Representative DSC curves of compounds extended $\mathbf{1 b}, \mathbf{2} \mathbf{c}$ and $\mathbf{3 b}$ determined with a scanning rate of $3{ }^{\circ} \mathrm{C} / \mathrm{min}$ under $\mathrm{N}_{2}$.

All compounds 1-4 exhibited relatively sharp peaks of melting and gradual decomposition processes. In the case of $\mathbf{2 a}-\mathbf{b}, \mathbf{3 a}, \mathbf{3 d}$ and $\mathbf{4 a}$ the dehydration/desorption of residual water/solvent was recorded within the range of $80-125^{\circ} \mathrm{C}$. Compounds $\mathbf{2 b}\left(195-205{ }^{\circ} \mathbf{C}\right), \mathbf{3 a}$ $\left(160-170{ }^{\circ} \mathrm{C}\right), \mathbf{3 b}\left(205-215{ }^{\circ} \mathrm{C}\right)$ and $4 \mathbf{a}\left(180-190{ }^{\circ} \mathrm{C}\right)$ underwent exothermic, irreversible monotropic solid-solid transition of metastable crystals. A slow solid-solid transition was also observed for $\mathbf{2 a}$, which showed metastable form melting at about $200{ }^{\circ} \mathrm{C}$ and immediate crystallization to a more stable form. Compound 3d showed two/three crystalline forms 
successively melting within the range of 237 to $246{ }^{\circ} \mathrm{C}$. Slow monotropic solid-solid transition was observed for $\mathbf{4 a}$ whose $\alpha^{\prime}$-form melted $\left(208{ }^{\circ} \mathrm{C}\right)$ briefly before the melting of $\alpha$-form $\left(215^{\circ} \mathrm{C}\right)$. Pyridazine derivatives $\mathbf{1 a}-\mathbf{c}$ and pyrimidine $\mathbf{2 d}$ are not stable in liquid phase, their melting processes were immediately followed by distinctive decomposition. A gradual decomposition in liquid phase was observed for pyrimidine $\mathbf{2 a - c}$ and benzene/thiophene derivatives $\mathbf{3 b} / \mathbf{3 d}$. On the contrary, compounds $\mathbf{3 a} / \mathbf{3 c}$ and $\mathbf{4 a}-\mathbf{4 b}$ were stable in liquid phase for additional $70-100{ }^{\circ} \mathrm{C}$ above their melting points.

In general, all target chromophores exhibited large thermal robustness. However the diazine compounds 1-2 showed slightly higher thermal stability in respect to benzene/thiophene analogues 3. Regardless on the $\pi$-backbone, a very narrow decomposition window of about $35{ }^{\circ} \mathrm{C}$ was revealed for all compounds $\mathbf{1}-\mathbf{3}$. The highest thermal robustness in this series was recorded for pyrimidine derivative $2 \mathbf{d}$ with $T_{\mathrm{m}} / T_{\mathrm{d}}$ above $300{ }^{\circ} \mathrm{C}$. Thermal behaviour of $\mathbf{4 a}-\mathbf{b}$ with shorter $\pi$-benzene linkers falls within the whole series with $T_{\mathrm{m}}$ and $T_{\mathrm{d}}$ above 200 and 300 ${ }^{\circ} \mathrm{C}$, respectively. The latter showed the highest $T_{\mathrm{d}}$ of $330{ }^{\circ} \mathrm{C}$.

Table 1. Summarized thermal and electrochemical properties of chromophores 1-4.

\begin{tabular}{cccccccccc}
\hline Compound & $\begin{array}{c}T_{\mathrm{m}}{ }^{[\mathrm{a}]} \\
\left({ }^{\circ} \mathrm{C}\right)\end{array}$ & $\begin{array}{c}T_{\mathrm{d}}^{[\mathrm{b}]} \\
\left({ }^{\circ} \mathrm{C}\right)\end{array}$ & $\begin{array}{c}E_{1 / 2(\mathrm{oxx})}(\mathrm{C}) \\
(\mathrm{V})\end{array}$ & $\begin{array}{c}E_{(\mathrm{red1})}(\mathrm{C}) \\
(\mathrm{V})\end{array}$ & $\begin{array}{c}\Delta E^{[\mathrm{c}]} \\
(\mathrm{V})\end{array}$ & $\begin{array}{c}E_{\mathrm{HOMO}}{ }^{[\mathrm{d}]} \\
(\mathrm{eV})\end{array}$ & $\begin{array}{c}E_{\mathrm{LUMO}} \\
(\mathrm{eV})\end{array}$ & $\begin{array}{c}\lambda_{\max }[\mathrm{c}] \\
(\mathrm{nm} / \mathrm{eV})\end{array}$ & $\begin{array}{c}\varepsilon_{\max } \cdot 10^{3[\mathrm{e}]} \\
\left(\mathrm{M}^{-1} \cdot \mathrm{cm}^{-1}\right)\end{array}$ \\
\hline $\mathbf{1 a}$ & 270 & 282 & 0.60 & -1.40 & 2.00 & -5.40 & -3.40 & $442 / 2.81$ & 20.9 \\
$\mathbf{1 b}$ & 291 & 295 & 0.59 & -1.39 & 1.98 & -5.39 & -3.41 & $449 / 2.76$ & 36.1 \\
$\mathbf{1 c}$ & 260 & 270 & 0.44 & -1.39 & 1.83 & -5.24 & -3.41 & $454 / 2.73$ & 25.5 \\
$\mathbf{2 a}$ & 232 & 290 & 0.59 & -1.44 & 2.03 & -5.39 & -3.36 & $443 / 2.80$ & 29.8 \\
$\mathbf{2 b}$ & 253 & 298 & 0.59 & -1.41 & 2.00 & -5.39 & -3.39 & $450 / 2.75$ & 25.8 \\
$\mathbf{2 c}$ & 275 & 298 & 0.58 & -1.37 & 1.95 & -5.38 & -3.43 & $451 / 2.75$ & 38.1 \\
$\mathbf{2 d}$ & 302 & 306 & 0.45 & -1.37 & 1.82 & -5.25 & -3.43 & $459 / 2.70$ & 33.1 \\
$\mathbf{3 a}$ & 206 & 306 & 0.51 & -1.45 & 1.96 & -5.31 & -3.35 & $444 / 2.79$ & 21.7 \\
$\mathbf{3 b}$ & 279 & 298 & 0.49 & -1.47 & 1.96 & -5.29 & -3.33 & $470 / 2.64$ & 42.2 \\
$\mathbf{3 c}$ & 230 & 302 & 0.43 & -1.43 & 1.86 & -5.23 & -3.37 & $459 / 2.70$ & 41.3 \\
$\mathbf{3 d}$ & 237 & 290 & 0.44 & -1.42 & 1.86 & -5.24 & -3.38 & $506 / 2.45$ & 36.5 \\
$\mathbf{4 a}$ & 215 & 302 & 0.58 & -1.42 & 1.99 & -5.38 & -3.38 & $505 / 2.46$ & 46.3 \\
$\mathbf{4 b}$ & 230 & 330 & 0.61 & -1.59 & 2.20 & -5.40 & -3.20 & $490 / 2.53$ & 25.9 \\
\hline
\end{tabular}

${ }^{\text {[a] }} T_{\mathrm{m}}=$ melting point (the point of intersection of a baseline and a tangent of thermal effect $=$ oneset). ${ }^{[\mathrm{b}]} T_{\mathrm{d}}=$ thermal decomposition (pyrolysis in $\mathrm{N}_{2}$ atmosphere). ${ }^{[\mathrm{c}]} E_{1 / 2(\mathrm{ox} 1)}$ and $E_{(\mathrm{red} 1)}$ are potentials of the first oxidation and reduction (half- 
wave for oxidation), respectively, as measured by $\mathrm{CV}$; all potentials are given $v$ s ferrocene as internal reference $(E=0.51 \mathrm{~V}$
vs. Ag electrode); $\Delta E=E_{1 / 2(\mathrm{ox} 1)}-E_{(\mathrm{red} 1)}{ }^{[\mathrm{d}]}-E_{\mathrm{HOMO} / \mathrm{LUMO}}=E_{1 / 2(\mathrm{ox} 1 / \mathrm{red} 1)}+4.8$ (Ref.22). ${ }^{\text {el] }}$ Measured in $\mathrm{CHCl}_{3}$ at $c \approx 10^{-5} \mathrm{M}$.

\section{Electrochemistry}

Electrochemical measurements of chromophores 1-4 were carried out in $\mathrm{CH}_{2} \mathrm{Cl}_{2}$ containing $0.1 \mathrm{M} \mathrm{Bu}_{4} \mathrm{NBF}_{4}$ in a three electrode cell by cyclic voltammetry (CV) (see experimental details). All potentials were measured $v s$. Ag electrode and are given vs. ferrocene as internal standard. The acquired data are summarized in Table 1 . The half-wave potential $\left(E_{1 / 2(\mathrm{ox} 1)}\right)$ of the first oxidation and the reduction potential $E_{(\text {red1) }}$ were acquired within the range of 0.43 to 0.61 and -1.59 to $-1.37 \mathrm{~V}$, respectively. The first oxidation and reduction are typical oneelectron processes, followed by subsequent oxidations and reductions. Whereas the first oxidations of 1-4 were reversible or quasi-reversible, all first reductions were irreversible processes. According to the literature, ${ }^{23}$ the first oxidation is most likely localized on the triphenylamine donor and the adjacent part of the $\pi$-linker, the first reduction process mostly involves ThDione acceptor. The half-wave potential of the first oxidation and reduction were further recalculated to the energies of the HOMO and the LUMO and these values were visualized for compounds $\mathbf{1}-\mathbf{3}$ in the energy level diagram (Figure 3 ). ${ }^{24}$

With the same electron donor and acceptor in chromophores $\mathbf{1 - 3}$, the observed variations in $E_{1 / 2(\mathrm{ox} 1)}$ and $E_{(\mathrm{red} 1)}$ are obviously dependent on the type and extent of the used $\pi$-linker (Table 1). In the case of molecules $\mathbf{4 a} \mathbf{a}-\mathbf{4 b}$, the variations of $E_{1 / 2(\mathrm{ox} 1)}$ and $E_{(\mathrm{red} 1)}$ are predominantly function of the $\pi$-linker length. 


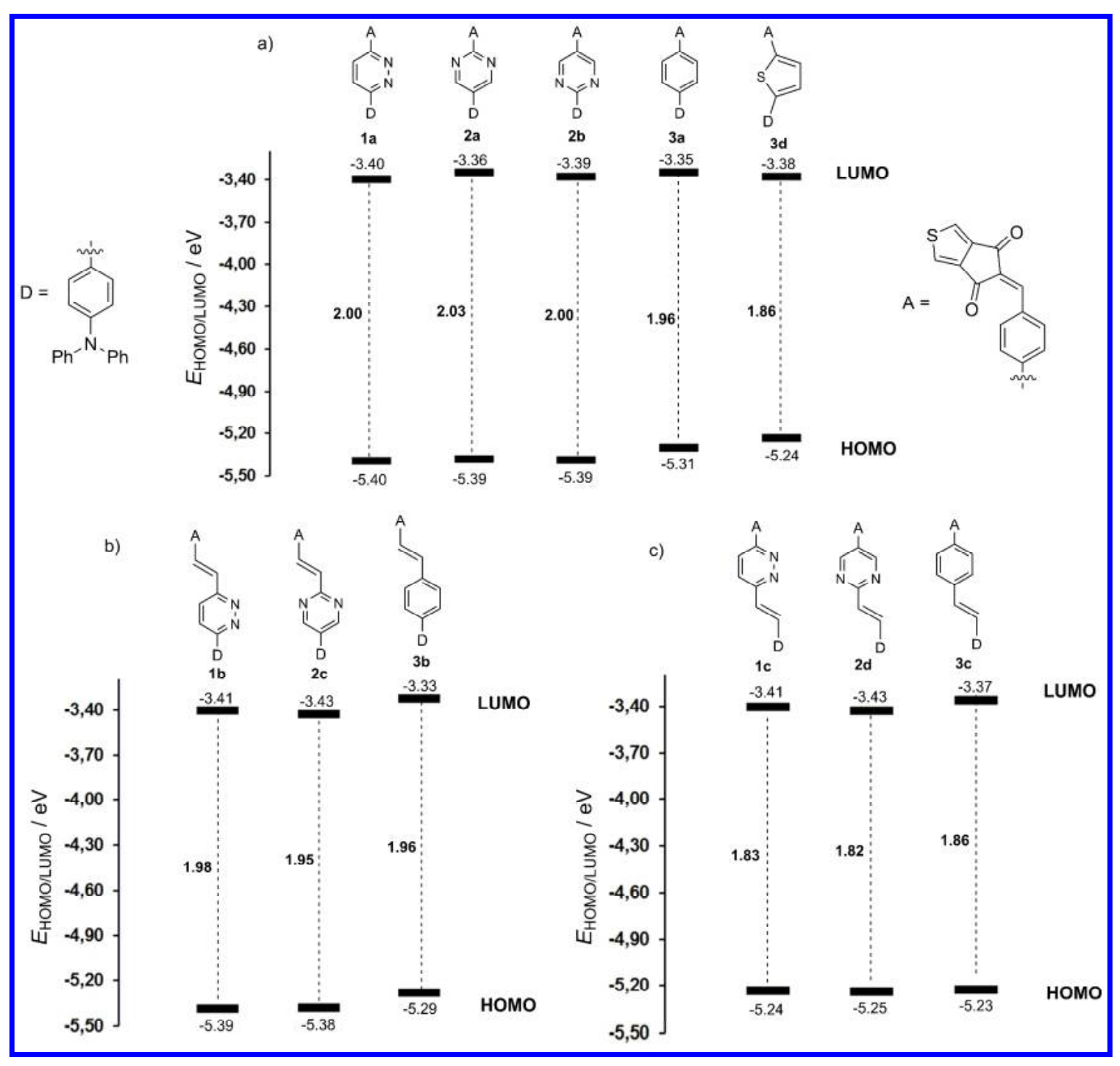

Figure 3. Energy level diagrams of final chromophores 1-3.

Whereas the LUMO energies become steady within the range from -3.33 to $-3.43 \mathrm{eV}$ for chromophores 1-3, the principal changes are seen in the HOMO levels. For instance, the LUMO levels of chromophores bearing heterocyclic $\pi$-linkers $(\mathbf{1 a}-\mathbf{c}, \mathbf{2 b}-\mathbf{d}$, and $\mathbf{3 d})$ possess almost identical $E_{\mathrm{LUMO}}$ values of about $-3.40 \mathrm{eV}$. The chromophores $\mathbf{3 a}-\mathbf{c}$ with 1,4-phenylene moieties showed only slightly increased values to about $-3.35 \mathrm{eV}$. The electrochemical HOMO-LUMO gap $(\Delta E)$, which represents the most straightforward way for evaluating the $\pi$-system variation, is mostly dictated by the HOMO levels. Hence, with the HOMO energies 
ranging from -5.23 to $-5.40 \mathrm{eV}$, the $\Delta E$ values are affected by the following structural features:

- The placement of the olefinic subunit. Whereas ethenylene subunit inserted closely to the acceptor (e.g. 1b, 2cc, and 3b; $\Delta E=1.98,1.95$, and $1.96 \mathrm{eV}$; Figure 3b) has only diminished effect compared to 1a, 2a, and 3a $(\Delta E=2.00,2.03$, and $1.96 \mathrm{eV}$; Figure 3a), its placement on the donor side (e.g. 1c, $2 d$, and 3c; $\Delta E=1.83,1.82$, and $1.86 \mathrm{eV}$; Figure 3c) reduced the HOMO-LUMO gap by $0.1-0.2 \mathrm{eV}$.

- Orientation of the heteroaromatic ring (e.g. pyrimidine in $\mathbf{2 a}$ and $\mathbf{2 b}$ ) affected the $\Delta E$ only negligibly (2.03 and $2.00 \mathrm{eV}$; Figure 3a).

- The type of six-membered (hetero)aromatic $\pi$-linker embedded in the chromophore $\pi$-backbone plays only minor role (e.g. $\mathbf{1 a} \rightarrow \mathbf{2 a} / \mathbf{2} \mathbf{b} \rightarrow \mathbf{3 a}$; pyridazine $\rightarrow$ pyrimidine $\rightarrow$ benzene; $\Delta E=2.00 \rightarrow 2.03 / 2.00 \rightarrow 1.96 \mathrm{eV}$; Figure 3 a).

- The lowest HOMO-LUMO gaps were electrochemically measured for chromophores 1c, 2d, and 3c with pyridazine, pyrimidine, and benzene units and the $\pi$-system extended closely to the triphenylamine donor (Figure 3b).

- Polarizable 2,5-thienylene moiety embedded in the chromophore $\pi$-backbone as in $\mathbf{3 d}$ showed similar ICT transparency with $\Delta E$ equal to $1.86 \mathrm{eV}$ without additional extension of the $\pi$-system (Figure 3a).

In summary, the electrochemical investigations of chromophores 1-3 revealed only minor influence of the benzene vs. pyridazine/pyrimidine $\pi$-linkers. Based on these measurements, we can assume similar polarizability and extent of the ICT across these $\pi$-linkers.

Figure 4 depicts the influence of $\pi$-linker length (number of 1,4-phenylene units) on the electronic behaviour of chromophores $3 \mathbf{a}$ and $\mathbf{4 a}-\mathbf{b}$. As expected, the elongation of the $\pi$-conjugated system linker narrowed the electrochemical gap, especially when going from $\mathbf{4 b}$ 
to $\mathbf{4 a}(\Delta E=2.20$ vs. $1.99 \mathrm{eV})$. Insertion of the third 1,4-phenylene unit as in $\mathbf{3 a}$ influenced the HOMO/LUMO levels only negligibly. This saturation is in accordance with our previous observation that ICT transmittance across three or more phenylene units is diminished. ${ }^{25}$

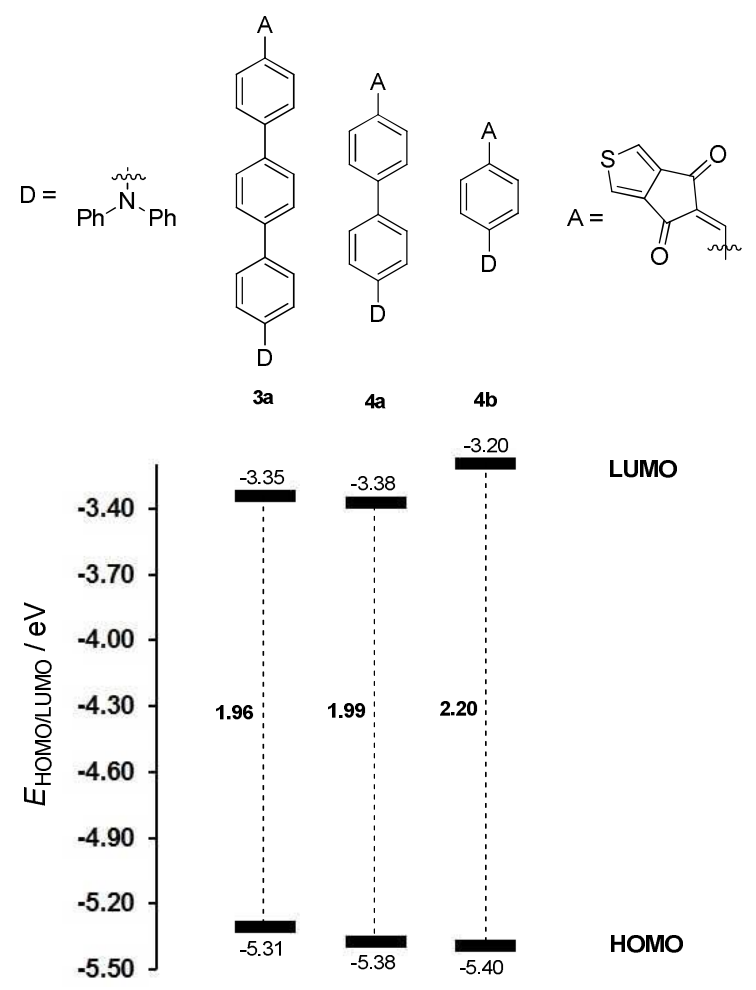

Figure 4. Energy level diagram of final chromophores $3 \mathbf{a}$ and $\mathbf{4 a} \mathbf{a}-\mathbf{4 b}$.

\section{UV-vis spectroscopy}

The UV-Vis electronic spectra of target chromophores 1-4 were recorded in chloroform (Figure 5), the fundamental linear optical properties are summarized in Table 1. TD-DFT calculated UV-Vis spectra (a representative spectrum for 3a is provided in Fig. S39) revealed HOMO to LUMO transition appearing at around $590 \mathrm{~nm}$. However, experimental spectra showed the longest wavelength absorption maxima $\left(\lambda_{\max }\right)$ within the range of 442-506 nm. These correspond to a HOMO-1 to LUMO and HOMO to LUMO+1 transitions. As indicated by the TD-DFT calculations, the oscillator strength of the pure HOMO to LUMO transition is significantly affected by rotation of the particular 1,4-phenylene (or diazine) units and 
therefore are predicted to be not visible (dihedral angle of about $40^{\circ}$ ). The observed high energy bands are most likely populated by the most stable rotamers, which, in addition, would also indicate low or no emissive character of target chromophores. Experimental optical gaps (1240/ $\left.\lambda_{\max }\right)$ for molecules 1-4 were visualized in Figure 6 , TD-DFT obtained values are correlated in the SI (Fig. S40). As can be seen, the general trends deduced from the electrochemical measurements are also obeyed in absorption behavior of 1-3. Namely, pyridazine, pyrimidine, and benzene derivatives $\mathbf{1 a}, \mathbf{2 a} / \mathbf{b}$, and $\mathbf{3 a}$ exhibited optical gaps within a narrow range of $2.75-2.81 \mathrm{eV}$. Pyrimidine analogues $\mathbf{2 a}$ and $\mathbf{2 b}$ showed almost identical optical gaps of 2.80 and $2.75 \mathrm{eV}$ resembling the eletrochemicaly measured ones (2.03 and $2.00 \mathrm{eV})$. Hence, the orientation of the electron donor and the acceptor does not affect the optical properties significantly. Insertion and placement of an additional olefinic subunit reduced the optical gaps most significantly. In the benzene series $\mathbf{3 a}-\mathbf{c}$, this effect is more pronounced when the ethenylene subunits separates the acceptor part (compare $\mathbf{3 b}$ vs. 3a) than the triphenylamine donor (3c vs. 3a). This is in a slight contradiction to the electrochemical data. However, the optical behavior of chromophores $\mathbf{1}$ and $\mathbf{2}$ mimics exactly the trends seen by the aforementioned electrochemical measurements. The most bathochromically shifted CT-band $\left(\lambda_{\max }=506 \mathrm{~nm}\right)$ and the lowest optical gap $(2.45 \mathrm{eV})$ has been measured for thiophene derivative $\mathbf{3 d}$.

Surprisingly, absorption CT-bands of shorter $\pi$-benzene analogues $\mathbf{4 a - 4 b}$ are significantly red-shifted compared to other chromophores $\mathbf{1}-\mathbf{3}$, especially with benzene derivative $\mathbf{3 a}$ (Fig. $5 \mathrm{c}$ and 6). This optical behavior is inconsistent with the electrochemical conclusions (decreased $\Delta \mathrm{E}$ value when the number of 1,4-phenylene units is increased). The observed red shift for $\mathbf{4 a}$ and $\mathbf{4 b}$, relative to $\mathbf{1 - 3}$, may be due to their shorter pi-linker, that may lead to the stronger DA interaction in the excited states. 


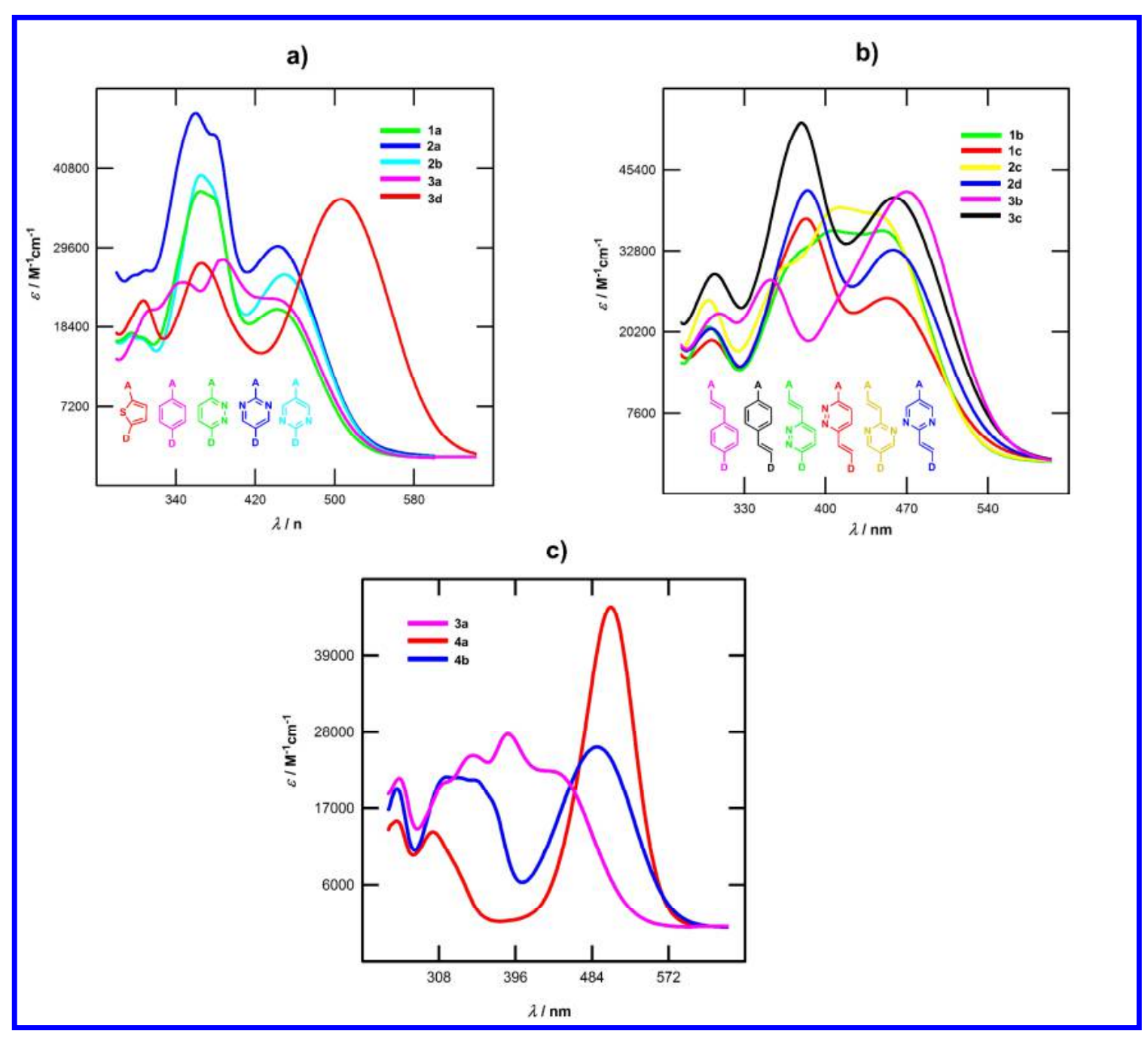

Figure 5. UV-Vis spectra of chromophores 1-4 measured in chloroform $\left(\mathrm{c} \sim 10^{-5} \mathrm{M}\right)$. 


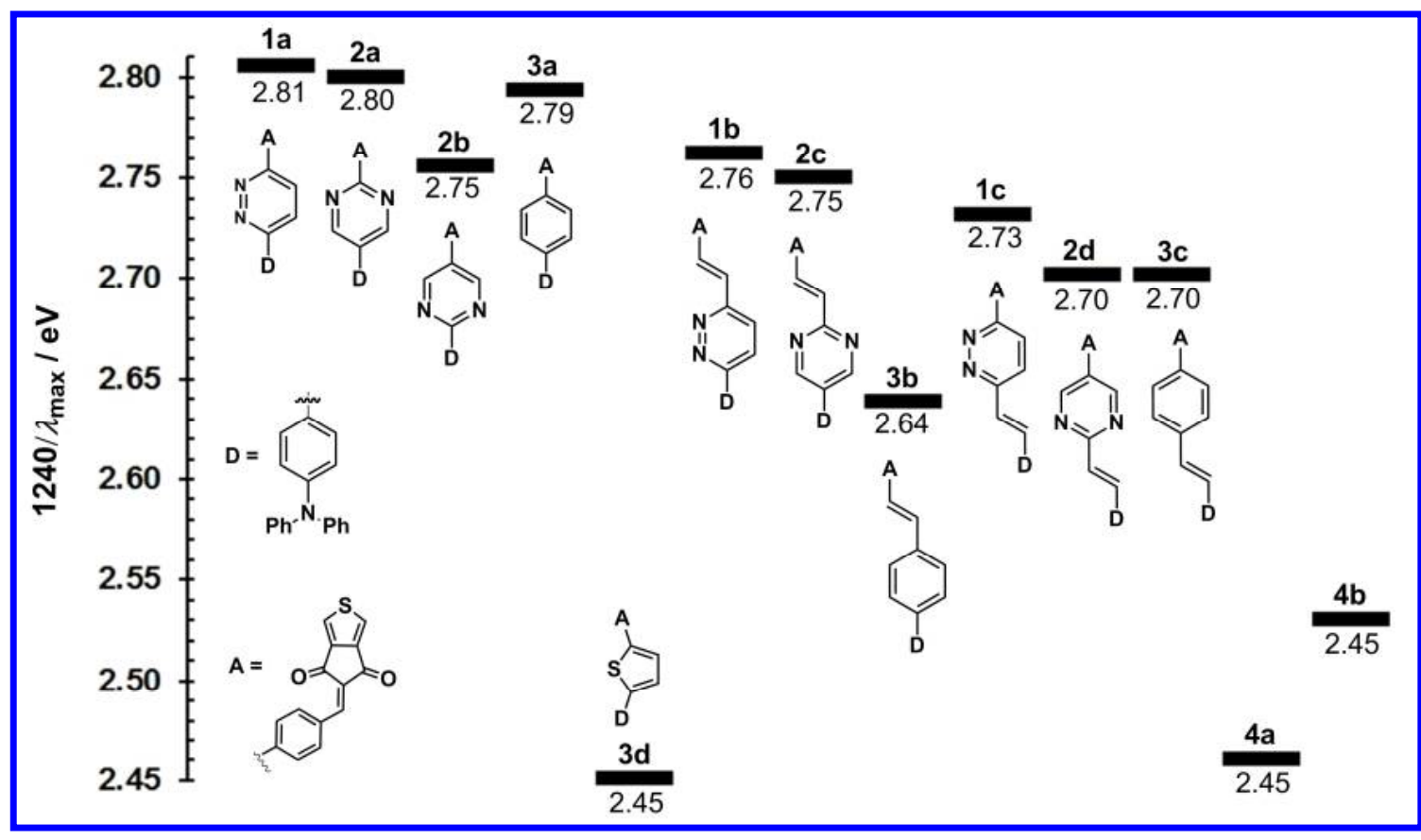

Figure 6. Comparison of energy gaps of chromophores 1-4 in chloroform.

The absorption data of target chromophores 1-4 in three selected solvents of different polarity (toluene, chloroform, and methanol) are shown in the SI (Fig. S6-S7). When going from less polar toluene to more polar chloroform, the CT-bands have shifted only negligibly $\left(\Delta \lambda_{\max }=\right.$ 0-9 $\mathrm{nm}$ ). This undistinguished solvatochromic behavior is a common feature of similar diazine push-pull chromophores. ${ }^{10}$ However, in contrast to benzene/thiophene chromophores 3-4, the absorption spectra of 1-2 measured in protic methanol showed significantly suppressed and hypsochromically shifted CT-bands as a result of nonspecific hydrogenbonding of the solvent to the central diazine moiety. ${ }^{26}$

\section{Emission spectroscopy}

In contrast to final chromophores 1-3 that are non-emissive, aldehyde precursors $\mathbf{5 a}, \mathbf{6 a}-\mathbf{b}$, 7a, and 7d are highly fluorescent probably due to the weaker electron-withdrawing property of the formyl fragment compared with ThDione. As these molecules also represent push-pull 
molecules, we have investigated their UV-Vis and photoluminescence (PL) spectroscopic properties in chloroform. Table 2 summarizes the gathered data, representative spectra are shown in the SI (Fig. S9-S10). All these compounds display yellow emission in chloroform with high fluorescence quantum yield (0.34-0.78) and large Stokes shifts, which is a clear indication of the high polarizability of their $\pi$-conjugated systems due to the ICT. Push-pull luminophores generally exhibit intense emission solvatochromism. More precisely, broad structureless red-shifted emission is observed on increasing the solvent polarity along with a successive decrease of the fluorescence intensity due to the stabilization of highly polar emitting state by polar solvents. ${ }^{10 \mathrm{e}-\mathrm{h}, 27}$ The emission behavior of selected aldehydes was studied in a variety of different aprotic solvents and the results are reported in Table 3. All compounds show a distinct positive emission solvatochromism. When increasing solvent polarity (according to the Dimroth-Reichardt polarity parameter $\left.\mathrm{E}_{\mathrm{T}}(30)\right){ }^{28}$ a bathochromic shift of the emission band has clearly been observed. As an example, the color changes under UV irradiation for compound $\mathbf{6 b}$ in various solvents are shown in SI (Fig. S12). The emission maxima plotted versus $\mathrm{E}_{\mathrm{T}}(30)$ showed a good correlation and linearity for all five aldehydes (Fig. S11). Surprisingly, the weakest solvatochromic range, proportional to the slope of the regression line, is observed for the thiophene derivative $\mathbf{7 d}$, whereas the highest is observed for the pyridazine aldehyde 5a. Although this fluoro-solvatochromic study does not quantify the ICT, it may serve as a clear indicator of its occurrence in $\mathbf{5 a}, \mathbf{6} \mathbf{a}-\mathbf{b}, \mathbf{7 a}$, and $\mathbf{7 d}$.

Table 2: UV/Vis and PL of selected aldehydes in $\mathrm{CHCl}_{3}$.

\begin{tabular}{ccccc}
\hline Compound & $\begin{array}{c}\lambda_{\max }^{a b a} \\
(\mathrm{~nm} / \mathrm{eV})\end{array}$ & $\begin{array}{c}\lambda_{\max }^{P L}{ }^{[\mathrm{a}]} \\
(\mathrm{nm} / \mathrm{eV})\end{array}$ & $\Phi_{\mathrm{F}}{ }^{[\mathrm{b}]}$ & $\begin{array}{c}\text { Stokes shift } \\
\left(\mathrm{cm}^{-1}\right)\end{array}$ \\
\hline $\mathbf{5 a}$ & $395 / 3.14$ & $557 / 2.23$ & 0.34 & 7363 \\
$\mathbf{6 a}$ & $391 / 3.17$ & $558 / 2.22$ & 0.63 & 7654 \\
$\mathbf{6 b}$ & $398 / 3.12$ & $550 / 2.25$ & 0.78 & 6944 \\
$\mathbf{7 a}$ & $366 / 3.39$ & $563 / 2.20$ & 0.45 & 9650 \\
$\mathbf{7 d}$ & $411 / 3.02$ & $566 / 2.19$ & 0.75 & 6663 \\
\hline
\end{tabular}


${ }^{\text {[a] }}$ All spectra were recorded at room temperature at $c=1.0 \times 10^{-5} \mathrm{M}$ to $3.0 \times 10^{-5}$. ${ }^{\text {[b] }}$ Fluorescence quantum yield $( \pm 10 \%)$ determined relative to 9,10 -bis(phenylethynyl)anthracene in cyclohexane $\left(\Phi_{\mathrm{F}}=1.00\right)$.

Table 3: Emission solvatochromism of selected aldehydes in various aprotic solvents.

\begin{tabular}{|c|c|c|c|c|c|c|c|}
\hline Compound & $\begin{array}{c}\text { Heptane } \\
\lambda_{\max }^{P L} \\
(\mathrm{~nm}) \\
30.9^{[\mathrm{ad}]}\end{array}$ & $\begin{array}{c}\text { Toluene } \\
\lambda_{\max }^{P L} \\
(\mathrm{~nm}) \\
33.9^{\text {[a] }}\end{array}$ & $\begin{array}{l}\text { THF } \\
\lambda_{\max }^{P L} \\
(\mathrm{~nm}) \\
37.4^{[\mathrm{a}]}\end{array}$ & $\begin{array}{c}\mathrm{CH}_{2} \mathrm{Cl}_{2} \\
\lambda_{\max }^{P L} \\
(\mathrm{~nm}) \\
40.7^{[\mathrm{a}]}\end{array}$ & $\begin{array}{c}\text { Acetone } \\
\lambda_{\max }^{P L} \\
(\mathrm{~nm}) \\
42.2^{[\mathrm{a}]}\end{array}$ & $\begin{array}{c}\mathrm{CH}_{3} \mathrm{CN} \\
\lambda_{\max }^{P L} \\
(\mathrm{~nm}) \\
45.6^{[\mathrm{a}]}\end{array}$ & $\begin{array}{c}\text { DMSO } \\
\lambda_{\max }^{P L} \\
(\mathrm{~nm}) \\
45.1^{[\mathrm{a}]}\end{array}$ \\
\hline $5 a$ & $-^{[\mathrm{b}]}$ & 433 & 552 & 592 & 640 & $-^{[b]}$ & $-^{[b]}$ \\
\hline $6 \mathbf{a}$ & 440 & 478 & 558 & 607 & 632 & - $^{[b]}$ & ${ }_{-}^{[b]}$ \\
\hline $6 \mathbf{b}$ & 449 & 482 & 546 & 578 & 609 & 626 & 648 \\
\hline $7 a$ & 438 & 467 & 532 & 583 & 603 & $L^{[b]}$ & 646 \\
\hline 7d & 480 & 500 & 541 & 578 & 590 & 616 & 622 \\
\hline
\end{tabular}

\section{EFISH experiments}

The second-order NLO responses of chromophores 1-3 were measured by the EFISH technique in $\mathrm{CHCl}_{3}$ solution with a non resonant incident wavelength of $1907 \mathrm{~nm}$. The second harmonic at $\lambda=953 \mathrm{~nm}$ stay well clear of the absorption bands of the chromophores. Experimental details on EFISH measurements are given elsewhere. ${ }^{29}$ EFISH measurements provide information about the scalar product $\mu \beta(2 \omega)$ of the vector component of the first hyperpolarisability tensor $\beta$ and the dipole moment vector. ${ }^{30}$ This product is derived according to equation 1 and considering $\gamma_{0}(-2 \omega, \omega, \omega, 0)$, the third-order term, as negligible for the push-pull compounds under consideration. This approximation is usually used for pushpull organic and organometallic molecules.

$$
\gamma_{\text {EFISH }}=\mu \beta / 5 \mathrm{k} T+\gamma_{0}(-2 \omega, \omega, \omega, 0) \quad \text { Eq. } 1
$$

Table 4. $\mu \beta$ values for compounds 1-3.

\begin{tabular}{cccccccccccc}
\hline & 1a & 1b & 1c & 2a & 2b & 2c & 2d & 3a & 3b & 3c & 3d \\
\hline$\mu \beta\left[10^{-48} \mathrm{esu}\right]^{[a]}$ & 220 & 300 & 290 & 220 & 70 & 410 & 50 & 150 & 330 & 330 & 530
\end{tabular}

${ }^{[a]} \mu \beta(2 \omega)$ at $1907 \mathrm{~nm}$ in $\mathrm{CHCl}_{3}$. Molecular concentrations used for the measurements were in the range $10^{-3}$ to $10^{-2}$ M. $\mu \beta \pm 10 \%$. 
All the $\mu \beta$ values for compounds 1-3 are positive indicating of excited states, which are more polarized than the ground state and that both ground and excited state are polarized in the same direction. The $\mu \beta$ values listed in Table 4 are comprised between 50 and $530 \times 10^{-48}$ esu. The following tendencies may be observed:

- As expected, extension of the $\pi$-conjugated core by addition of an ethenylene linker results in a significant enhancement of the NLO response (1a vs. $\mathbf{1 b}-\mathbf{c}, \mathbf{2 a} v s . \mathbf{2 c}$ and 3a vs. $\mathbf{3 b}-\mathbf{c}$ ) except in case of $\mathbf{2} \mathbf{b}$ and $\mathbf{2 d}$ that exhibit the lowest NLO responses.

- Orientation of the pyrimidine ring seems to be a key parameter: the NLO response of $\mathbf{2 a}$ and $\mathbf{2 c}$ being dramatically higher than that of $\mathbf{2 b}$ and $\mathbf{2 d}$ respectively. This trend is in contradiction with electrochemical and absorption data.

- The type of six-membered (hetero)aromatic $\pi$-linker in the chromophore scaffold significantly tunes the NLO response. The pyrimidine ring with electron-donating fragment in C5 position (2a and $\mathbf{2 c}$ ) seems to be the best configuration. When compared with their 1,4-phenylene analogues 3a-c, pyridazine derivatives $\mathbf{1}$ gave slightly increased or similar NLO values.

- Chromophore 3d with 2,5-thienylene moiety in the $\pi$-conjugated core exhibits the highest NLO response $\left(530 \times 10^{-48} \mathrm{esu}\right)$ in accordance with the most red-shifted CT absorption band observed for this compound.

\section{Quantum chemical calculations}

Spatial and electronic properties of all target chromophores 1-4 were investigated using Gaussian W09 package $^{31}$ at the DFT level. Initial geometries of molecules 1-4 were estimated by PM3 method implemented in ArgusLab ${ }^{32}$ and these were subsequently optimized by DFT B3LYP/6-311++G(2d,f,p) method. Energies of the HOMO and LUMO, their differences, ground state dipole moments $\mu$ and first hyperpolarizabilities $\beta$ at $1907 \mathrm{~nm}$ were also 
calculated on the DFT B3LYP/2P-311++G(2d,f,p) level in vacuum. All calculated data are summarized in Table 5.

Table 5. Calculated values of energies $E_{\text {Hомо/Lumo }}(\Delta E)$, dipole moments $(\mu)$, first hyperpolarizabilities $\beta$ and $\mu \beta$ coefficients for compounds 1-4.

\begin{tabular}{|c|c|c|c|c|c|c|}
\hline Compound & $\begin{array}{c}\Delta E \\
(\mathrm{eV})\end{array}$ & $\begin{array}{c}E_{\text {номо }}{ }^{[a]} \\
(\mathrm{eV})\end{array}$ & $\begin{array}{c}E_{\text {LUMo }}{ }^{[a]} \\
(\mathrm{eV})\end{array}$ & $\begin{array}{l}\mu^{[a]} \\
\text { (D) }\end{array}$ & $\begin{array}{c}\beta \cdot 10^{-30[a]} \\
(\mathrm{esu})\end{array}$ & $\begin{array}{c}\mu \beta \cdot 10^{-48[b]} \\
\left(\mathrm{esu}^{2} \cdot \mathrm{cm}\right)\end{array}$ \\
\hline $1 \mathbf{a}$ & 2.34 & -5.46 & -3.12 & 4.14 & 752 & 3113 \\
\hline $1 b$ & 2.25 & -5.42 & -3.17 & 4.40 & 1188 & 5227 \\
\hline $1 c$ & 2.27 & -5.40 & -3.13 & 5.33 & 1201 & 6401 \\
\hline $2 a$ & 2.46 & -5.54 & -3.08 & 5.34 & 587 & 3135 \\
\hline $2 b$ & 2.22 & -5.39 & -3.17 & 1.34 & 1007 & 1349 \\
\hline $2 c$ & 2.33 & -5.49 & -3.16 & 5.17 & 877 & 4534 \\
\hline $2 d$ & 2.19 & -5.35 & -3.16 & 2.41 & 1407 & 3391 \\
\hline $3 \mathbf{a}$ & 2.32 & -5.35 & -3.03 & 2.86 & 710 & 2031 \\
\hline $3 \mathbf{b}$ & 2.26 & -5.34 & -3.08 & 3.97 & 1219 & 4839 \\
\hline $3 c$ & 2.22 & -5.25 & -3.03 & 3.73 & 1311 & 4890 \\
\hline 3d & 2.30 & -5.33 & -3.03 & 4.27 & 1029 & 4394 \\
\hline $4 a$ & 2.46 & -5.44 & -2.98 & 3.28 & 576 & 1889 \\
\hline $4 b$ & 2.85 & -5.64 & -2.79 & 4.19 & 178 & 746 \\
\hline
\end{tabular}

${ }^{\text {[a] }}$ Calculated at the DFT B3LYP/2P-311++G(d,f,p) level; ${ }^{[\mathrm{b}]} 1 \mathrm{D}=1 \times 10^{-18} \mathrm{esu} \cdot \mathrm{cm}$.

As can be deduced from the energy level diagram shown in Figure 7, the DFT calculation slightly overestimates the electrochemical $E_{\mathrm{LUMO}}$ and fits relatively well the $E_{\mathrm{HOMO}}$. However, both these quantities as well as their differences showed reasonable correlations (Fig. S41-S43) and, therefore the used DFT method can be considered as a suitable tool for the description of electronic properties of 1-4. Similar conclusions as from electrochemical data can also be concluded from the DFT calculations. However, the following points should be highlighted:

- Insertion of the olefinic subunit slightly reduces the calculated gap $\Delta E$ by about $0.05-0.15$ eV (e.g. 1a vs. 1c/1d).

- Orientation of the pyrimidine ring affects the calculated $\Delta E$ more significantly for both doublet of chromophores $\mathbf{2 a / 2 b}$ and $\mathbf{2} \mathbf{c} / \mathbf{2 d}$ than what has been observed by electrochemical measurements (Table 1). 
- Similarly to electrochemical data, type of (hetero)cycle embedded in the chromophore $\pi$-backbone plays only minor role (e.g. $\mathbf{1 b} \rightarrow \mathbf{2 c} \rightarrow \mathbf{3 b}$; pyridazine $\rightarrow$ pyrimidine $\rightarrow$ benzene; $\Delta E=2.25 \rightarrow 2.33 \rightarrow 2.26 \mathrm{eV}$ ).

- Polarizable 2,5-thienylene moiety embedded in the chromophore $\pi$-backbone as in $\mathbf{3 d}$ showed similar calculated $\Delta E$ of $2.30 \mathrm{eV}$ as diazine/benzene analogous $1 \mathbf{a}(2.34 \mathrm{eV})$, $\mathbf{2 a} / \mathbf{2 b}(2.46 / 2.22 \mathrm{eV})$ and $\mathbf{3 a}(2.32 \mathrm{eV})$. This is in contrast to electrochemical data.

- Extension of the $\pi$-linker obviously narrowed the calculated gap $\Delta E$ (e.g. $\mathbf{4 b} \rightarrow \mathbf{4} \mathbf{a} \rightarrow \mathbf{3 a}$; $2.85 \rightarrow 2.46 \rightarrow 2.32 \mathrm{eV})$

- The lowest HOMO-LUMO gaps were calculated for chromophores $\mathbf{1 b}, \mathbf{2 d}$, and $\mathbf{3 c}$ with extended $\pi$-system based on pyridazine $(\mathbf{1 b} ; 2.25 \mathrm{eV})$, pyrimidine $(\mathbf{2 d} ; 2.19 \mathrm{eV})$, and benzene $(\mathbf{3 c} ; 2.22 \mathrm{eV})$ units.

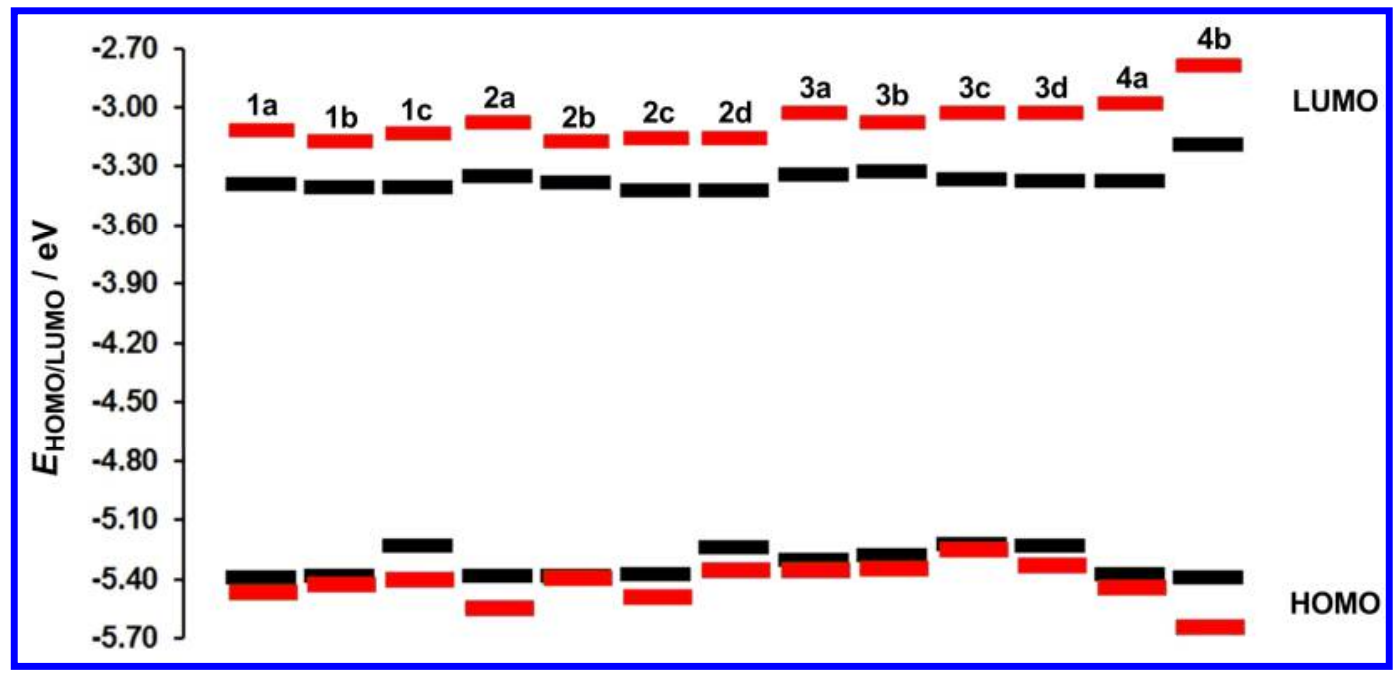

Figure 7. Energy level diagram of calculated energies $E_{\text {Hомо/Lumo at the DFT }}$ B3LYP/2P-311++G(d,f,p) level (red) and analogical electrochemical $E_{\mathrm{HOMO} / \mathrm{Lumo}}$ (black) for chromophores 1-4.

The HOMO and LUMO localizations in representative chromophores $\mathbf{1 c}, \mathbf{2 c}$ and $\mathbf{3 c}$ are shown in Figure 8. For complete listing see the SI (Fig. S26-S38). In general, the HOMO as well the HOMO-1 are localized on the triphenylamine donor in all target chromophores $\mathbf{1 - 4}$. The 
LUMO generally occupies ThDione acceptor and the adjacent olefinic unit. The LUMO+1 is spread either on the fused thiophene ring of the ThDione acceptor in benzene/thiophene compounds 3-4 or on the central diazine $\pi$-backbone of pyridazine/pyrimidine chromophores 1-2.

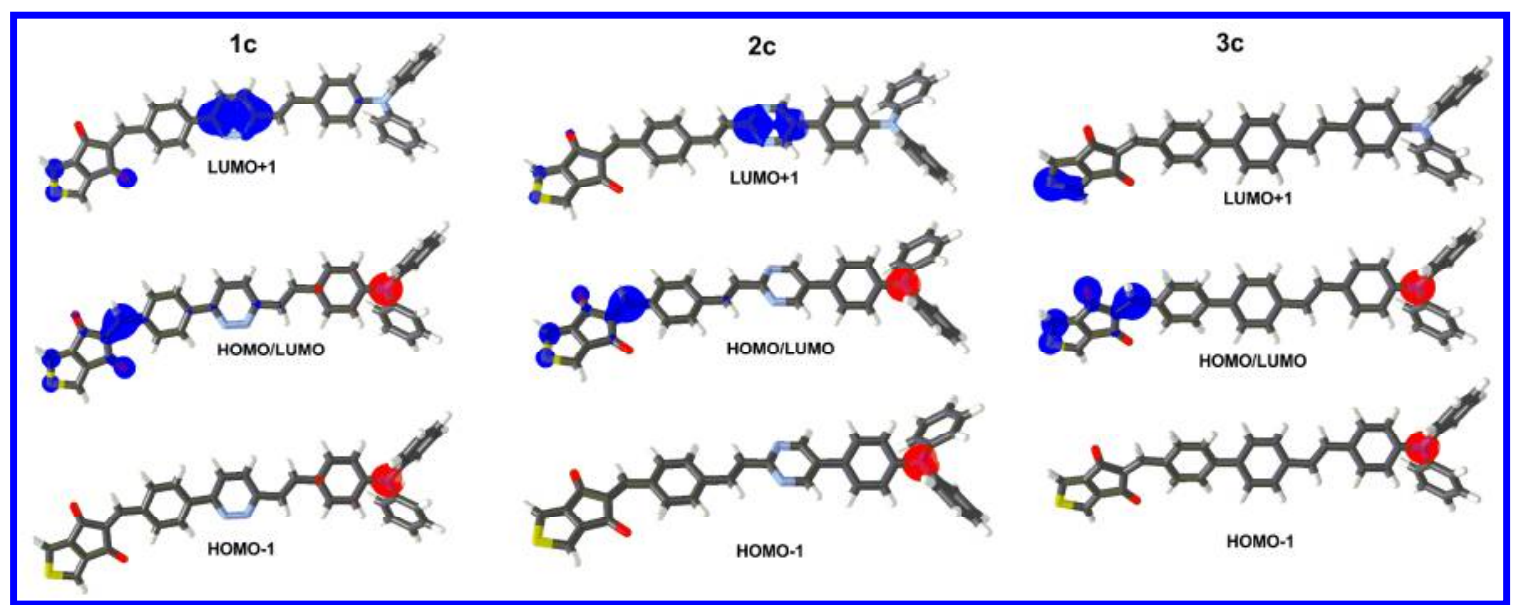

Figure 8. HOMO/HOMO-1 (red) and LUMO/LUMO+1 (blue) localizations and HOMO/LUMO mix in chromophores $\mathbf{1 c}, \mathbf{2 c}$ and $\mathbf{3 c}$.

The calculated ground state dipole moments range from 1.34 to $5.34 \mathrm{D}$ (Table 5). Their values in series $\mathbf{2}$ are dictated by the orientation of the pyrimidine ring. In $\mathbf{2 a}$ and $\mathbf{2} \mathbf{c}$ is pyrimidine oriented to behave as an acceptor and thus generate dipolar molecule with $\mu$ above $5 \mathrm{D}$, whereas in $\mathbf{2 b}$ and $\mathbf{2 d}$ is ground state dipole moment significantly reduced.

The calculated values of the first hyperpolarizabilities $\beta$ range from $180 \times 10^{-30}$ to $1400 \times 10^{-30}$ esu for target chromophores 1-4 (Table 5). As expected, the lowest $\beta$ values were calculated for less extended molecules $\mathbf{4 a} / \mathbf{4 b}\left(580 / 180 \times 10^{-30}\right.$ esu) as well as for compounds $\mathbf{1 a}, \mathbf{2 a}$ and 3a without embedded olefinic $\pi$-units $\left(750,590,710 \times 10^{-30} \mathrm{esu}\right)$. On the other hand, the highest $\beta$ values were gained for $\mathbf{1 c}, \mathbf{2 d}$ and $\mathbf{3 c}$ with extended $\pi$-linker $\left(1200,1400,1310 \times 10^{-}\right.$ 30 esu). In general, the calculated first hyperpolarizabilities do not depend on the type of central (hetero)aromatic $\pi$-backbone, but mostly on the $\pi$-linker extension as well as by orientation of the pyrimidine unit in series 2 . The latter property The calculated $\mu \beta$ products 
obey the trends of the experimental values obtained by EFISH experiment as can be deduced from their correlation (Fig S44 in SI).

\section{Conclusions}

In conclusion we have successfully synthesized a series of thirteen D- $\pi$-A chromophores bearing diphenylamino and ThDione fragments as electron-donor and acceptor respectively and various (hetero)aromatic ring as $\pi$-linkers. Whereas the 2,5-thienylene linker significantly enhances the polarizability of the chromophores when compared with 1,4-phenylene analogue as show by the red-shifted CT absorption band and narrowed electrochemical gap. Pyrimidine and pyridazine chromophores and their benzene analogues exhibit similar ICT. 2,5-Thienylene derivatives exhibits also the best NLO response $\left(\mu \beta=530 \times 10^{-48}\right.$ esu). Pyridazine chromophores and their benzene analogues exhibits similar NLO response whereas the orientation of the pyrimidine plays a significant role on the $\mu \beta$ value due to significantly higher $\mu$ values when the ThDione electron withdrawing group is localized on the C2-position of the pyrimidine ring. Taking into account that the aromaticity reduces the ICT, the position of CT band, electrochemical gap and NLO response seem to indicate a high aromaticity of pyrimidine and pyridazine derivatives, close to the benzene analogues and significantly higher than thiophene analogues.

\section{Experimental Section}

General Conditions. 5-Bromo-2-methylpyrimidine 29 was purchased from Interchim. The compound 34 was obtained according to reported procedure. ${ }^{33}$ In air- and moisture-sensitive reactions, all glassware was flame-dried and cooled under nitrogen. Thermal behavior of the target compounds were measured in open aluminous crucibles under $\mathrm{N}_{2}$ inert atmosphere. DSC curves were determined with a scanning rate of $3{ }^{\circ} \mathrm{C} / \mathrm{min}$ within the range $25-400{ }^{\circ} \mathrm{C}$. NMR spectra were acquired at room temperature. Chemical shifts are given in parts per 
million relative to TMS $\left({ }^{1} \mathrm{H}, 0.0 \mathrm{ppm}\right)$ and $\mathrm{CDCl}_{3}\left({ }^{13} \mathrm{C}, 77.0 \mathrm{ppm}\right)$. Acidic impurities in $\mathrm{CDCl}_{3}$ were removed by treatment with anhydrous $\mathrm{K}_{2} \mathrm{CO}_{3}$. High resolution MALDI MS spectra were measured on a MALDI mass spectrometer equipped with nitrogen UV laser $(337 \mathrm{~nm}, 60 \mathrm{~Hz})$ and quadrupole analyser (positive-ion mode over a normal mass range ( $\mathrm{m} / \mathrm{z}, 50-2000)$ with resolution 100000 at $\mathrm{m} / \mathrm{z}=400$ ). 2,5-Dihydroxybenzoic acid (DHB) were used as a matrix. Mass spectra were averaged over the whole MS record for all measured samples. UV-vis and fluorescence spectra were recorded using standard $1 \mathrm{~cm}$ quartz cells. Compounds were excited at their absorption maxima (band of lowest energy) to record the emission spectra. The $\Phi_{\mathrm{F}}$ values were calculated using a well-known procedure with 9,10-diphenylethynylanthracene in cyclohexane as standard. ${ }^{34}$ Stokes shifts were calculated by considering the lowest energetic absorption band. The electrochemical studies of the compounds were performed with a home-designed 3-electrodes cell (WE: Pt, RE: Ag wire, CE: Pt). Ferrocene was added at the end of each experiment to determine redox potential values. Anhydrous "extra-dry" dichloromethane was used as received and kept under $\mathrm{N}_{2}$. The potential were reported versus ferrocene as standard using a scan rate of $0.1 \mathrm{~V} / \mathrm{s}$. $\mathrm{NBu}_{4} \mathrm{BF}_{4} \mathrm{salt}$ was added as supporting electrolyte. All calculations were carried out in Gaussian 09W package at the DFT level of theory. The initial geometry optimizations were carried out by the PM3 method implemented in program ArgusLab and subsequently by the DFT B3LYP method using the $6-311 \mathrm{G}++(2 \mathrm{~d}, \mathrm{f}, \mathrm{p})$ basic set. The energies of the HOMO and LUMO $\left(E_{\mathrm{HOMO}}\right.$ and $\left.E_{\mathrm{LUMO}}\right)$, their differences $(\Delta E)$ and ground state dipole moments $(\mu)$ and first hyperpolarizabilities $\beta$ were calculated by the DFT B3LYP/6-311++G(2d,f,p) method.

General Procedure A for Suzuki Cross-Coupling Reactions. Aromatic halogeno derivative and boronic acid 10, 12 or 15 (1.1-1.25 eq.) were dissolved in the solution of toluene/EtOH (5:1, $25 \mathrm{~mL})$. Nitrogen was bubbled through the solution for $10 \mathrm{~min}$, whereupon $\mathrm{Pd}\left(\mathrm{PPh}_{3}\right)_{4}$ ( 0.05 eq.) and $\mathrm{Na}_{2} \mathrm{CO}_{3}$ (2 eq. of $1 \mathrm{M}$ water solution) were added, and the reaction mixture was 
stirred under nitrogen at reflux for 16 hours. The reaction mixture was cooled, filtered, and EtOAc/water 1:1 (50 mL) was added. The organic layer was separated and the aqueous layer extracted with additional EtOAc $(2 \times 25 \mathrm{~mL})$. The combined organic extracts were dried over $\mathrm{MgSO}_{4}$ and the solvents evaporated under reduced pressure. The crude product was purified by column chromatography $\left(\mathrm{SiO}_{2} ; \mathrm{CH}_{2} \mathrm{Cl}_{2}\right.$ to $\mathrm{CH}_{2} \mathrm{Cl}_{2}$ / EtOAc $\left.3: 1\right)$.

General Procedure B for Knoevenagel Condensation. Aldehyde and Th-dione 11 (2 eq.) were dissolved in $\mathrm{CH}_{2} \mathrm{Cl}_{2}(10 \mathrm{~mL})$ and a few drops of piperidine were added. The reaction mixture was stirred at $40{ }^{\circ} \mathrm{C}$ for 30 minutes. The solvent was slowly evaporated in vacuo and the crude product was purified by column chromatography $\left(\mathrm{SiO}_{2} ; \mathrm{CH}_{2} \mathrm{Cl}_{2} / \mathrm{EtOAc} 10: 1\right)$ followed by crystallization from $\mathrm{CH}_{2} \mathrm{Cl}_{2}$ /hexane.

General Procedure C for Hydrolysis of Acetal. The corresponding crude acetal was dissolved in wet acetone $(50 \mathrm{~mL})$ and a few drops of concentrated $\mathrm{HCl}$ were added. The reaction mixture was stirred at $40{ }^{\circ} \mathrm{C}$ for $1 \mathrm{~h}$. The reaction mixture was cooled, partially evaporated in vacuo and $\mathrm{CH}_{2} \mathrm{Cl}_{2} / \mathrm{NH}_{3}$ (5\% solution) 1:1 (100 ml) was added. The separated aqueous layer was extracted with $\mathrm{CH}_{2} \mathrm{Cl}_{2}(2 \times 20 \mathrm{~mL})$. The combined organic layers were dried over $\mathrm{MgSO}_{4}$ and evaporated. The corresponding crude aldehyde was purified by column chromatography $\left(\mathrm{SiO}_{2} ; \mathrm{CH}_{2} \mathrm{Cl}_{2}\right.$ to $\mathrm{CH}_{2} \mathrm{Cl}_{2}$ / EtOAc 10:1).

General Procedure D for Protection of Formyl Group. The corresponding benzaldehyde derivative and ethylene glycol (10 eq.) were dissolved in toluene $(10 \mathrm{~mL})$ and a few crystals of $\mathrm{TsOH}$ were added. The reaction mixture was refluxed for $16 \mathrm{~h}$, cooled and EtOAc/ $\mathrm{Na}_{2} \mathrm{CO}_{3}$ (10\% solution) 1:1 (100 ml) was added. The separated aqueous layer was extracted with EtOAc $(2 \times 20 \mathrm{~mL})$. The combined organic layers were dried over $\mathrm{MgSO}_{4}$ and evaporated. The crude acetal was used in next reaction step without further purification.

General Procedure E for Knoevenagel Condensation of Methyldiazine. The corresponding methyldiazine and the corresponding benzaldehyde $\mathbf{2 5}$ or $\mathbf{2 8}$ ( 2 or 1.1 eq.) were 
dissolved in DMSO (2 mL) and powdered $\mathrm{KOH}$ (4 eq.) was added. The reaction mixture was stirred at $20^{\circ} \mathrm{C}$ for $16 \mathrm{~h}$ and then was poured into water $(150 \mathrm{~mL})$. The precipitated acetal was filtered out and underwent of hydrolysis (general procedure $\mathrm{C}$ ) without further purification.

General Method F for Horner-Wadsworth-Emmons Olefination. 60\% $\mathrm{NaH}$ in mineral oil (1.5 eq.) was added to a solution of diethyl (4-bromobenzyl)-phosphonate $\mathbf{3 4}$ and the corresponding benzaldehyde (1.05 eq.) in toluene $(2-5 \mathrm{ml})$ at $0{ }^{\circ} \mathrm{C}$. The ice bath was removed after 10 minutes and the reaction mixture was refluxed for $16 \mathrm{~h}$. The reaction mixture was cooled and $\mathrm{CH}_{2} \mathrm{Cl}_{2} /$ water 1:1 (100 ml) was added. The separated aqueous layer was extracted with $\mathrm{CH}_{2} \mathrm{Cl}_{2}(2 \times 20 \mathrm{~mL})$. The combined organic layers were dried over $\mathrm{MgSO}_{4}$ and evaporated. After evaporation of solvents in vacuo the crude product was purified by column chromatography $\left(\mathrm{SiO}_{2} ; \mathrm{CH}_{2} \mathrm{Cl}_{2}\right)$.

4'-(Diphenylamino)-[1,1'-biphenyl]-4-carbaldehyde $\quad(8 \mathbf{a}) . \quad$ Synthesized from 4-bromotriphenylamine 9 (162 mg; $0.5 \mathrm{mmol})$ and 4-formylphenylboronic acid, pinacol ester 10 (139 mg; $0.6 \mathrm{mmol}$ ) following the general procedure A. Yield: $165 \mathrm{mg}$ (94\%); yellow amorphous solid; $R_{\mathrm{f}}=0.8\left(\mathrm{SiO}_{2} ; \mathrm{CH}_{2} \mathrm{Cl}_{2}\right) ; \mathrm{mp} 106-108{ }^{\circ} \mathrm{C} ;{ }^{1} \mathrm{H} \mathrm{NMR}\left(\mathrm{CDCl}_{3}, 300 \mathrm{MHz}\right): \delta=$ $7.06(\mathrm{t}, J=7.4 \mathrm{~Hz}, 2 \mathrm{H}), 7.13-7.15(\mathrm{~m}, 6 \mathrm{H}), 7.27-7.30(\mathrm{~m}, 4 \mathrm{H}), 7.50-7.52(\mathrm{~m}, 2 \mathrm{H}), 7.72(\mathrm{~d}, J$ $=8.2 \mathrm{~Hz}, 2 \mathrm{H}), 7.92(\mathrm{~d}, J=8.4 \mathrm{~Hz}, 2 \mathrm{H}), 10.02 \mathrm{ppm}(\mathrm{s}, 1 \mathrm{H})$. Data similar to the literature. ${ }^{35}$ 5-((4'-(Diphenylamino)-[1,1'-biphenyl]-4-yl)methylene)-4H-cyclopenta[c]thiophene4,6(5H)-dione (4a). Synthesized from 8a (150 mg; $0.429 \mathrm{mmol})$ and 11 (130 mg; 0.858 mmol) following the general procedure B. Yield: $85 \mathrm{mg}(41 \%)$; red solid; $R_{\mathrm{f}}=0.65\left(\mathrm{SiO}_{2}\right.$; $\left.\mathrm{CH}_{2} \mathrm{Cl}_{2}\right) ; \mathrm{mp} 215^{\circ} \mathrm{C} ;{ }^{1} \mathrm{H} \mathrm{NMR}\left(\mathrm{CDCl}_{3}, 300 \mathrm{MHz}\right): \delta=7.10(\mathrm{t}, J=7.0 \mathrm{~Hz}, 2 \mathrm{H}), 7.15-7.19(\mathrm{~m}$, 6H), 7.28-7.34 (m, 4H), $7.58(\mathrm{~d}, J=8.5 \mathrm{~Hz}, 2 \mathrm{H}), 7.74(\mathrm{~d}, \mathrm{~J}=8.5 \mathrm{~Hz}, 2 \mathrm{H}), 7.91(\mathrm{~s}, 1 \mathrm{H}), 8.03$ (s, 2H), $8.53 \mathrm{ppm}(\mathrm{d}, J=8.5 \mathrm{~Hz}, 2 \mathrm{H}) .{ }^{13} \mathrm{C} \mathrm{NMR}\left(\mathrm{CDCl}_{3}, 75 \mathrm{MHz}\right): \delta=123.0,123.5,125.0$, $125.5,125.6,126.5,127.9,129.4,131.5,132.8,135.2,136.1,145.4,145.7,147.3,147.4$, 
148.1, 148.5, 182.4, 183.3 ppm; IR (ATR): $\quad v=1714,1671 \mathrm{~cm}^{-1}$; HR-MALDI-MS (DHB): $m / z$ calculated for $\mathrm{C}_{32} \mathrm{H}_{22} \mathrm{NO}_{2} \mathrm{~S}[\mathrm{M}+\mathrm{H}]^{+} 484.13658$, found 484.13582 .

\section{5-(4-(Diphenylamino)benzylidene)-4H-cyclopenta $[c]$ thiophene-4,6(5H)-dione}

(4b). Synthesized from $\mathbf{8 b}(136 \mathrm{mg} ; 0.5 \mathrm{mmol})$ and $\mathbf{1 1}(152 \mathrm{mg} ; 1.0 \mathrm{mmol})$ following the general procedure B. Yield: $145 \mathrm{mg}(71 \%)$; orange-red solid; $R_{\mathrm{f}}=0.4\left(\mathrm{SiO}_{2} ; \mathrm{CH}_{2} \mathrm{Cl}_{2}\right) ; \mathrm{mp} 230{ }^{\circ} \mathrm{C} ;{ }^{1} \mathrm{H}$ $\operatorname{NMR}\left(\mathrm{CDCl}_{3}, 300 \mathrm{MHz}\right): \delta=7.01(\mathrm{~d}, J=9.0 \mathrm{~Hz}, 2 \mathrm{H}), 7.22-7.28(\mathrm{~m}, 6 \mathrm{H}), 7.36-7.41(\mathrm{~m}, 4 \mathrm{H})$, $7.76(\mathrm{~s}, 1 \mathrm{H}), 7.92-7.93(\mathrm{~m}, 2 \mathrm{H}), 8.40 \mathrm{ppm}(\mathrm{d}, J=9.0 \mathrm{~Hz}, 2 \mathrm{H}) .{ }^{13} \mathrm{C} \mathrm{NMR}\left(\mathrm{CDCl}_{3}, 75 \mathrm{MHz}\right): \delta$ $=118.8,124.6,124.7,125.6,126.6,129.8,133.1,137.0,145.7,145.8,147.4,148.1,152.9$, 182.9, $184.1 \mathrm{ppm}$; IR (ATR): $\quad v=1710,1666 \mathrm{~cm}^{-1}$; HR-MALDI-MS (DHB): $m / z$ calculated for $\mathrm{C}_{26} \mathrm{H}_{18} \mathrm{NO}_{2} \mathrm{~S}[\mathrm{M}+\mathrm{H}]^{+}$408.10528, found 408.10498.

4-(6-Chloropyridazin-3-yl)benzaldehyde (14). Synthesized from 3,6-dichloropyridazine 13 (745 mg; $5.0 \mathrm{mmol})$ and 4-formylphenylboronic acid $12(825 \mathrm{mg} ; 5.50 \mathrm{mmol})$ following the general procedure A. Yield: $210 \mathrm{mg}(20 \%)$; brownish solid; $R_{\mathrm{f}}=0.35\left(\mathrm{SiO}_{2} ; \mathrm{CH}_{2} \mathrm{Cl}_{2}\right)$; mp 183-184 ${ }^{\circ} \mathrm{C} ;{ }^{1} \mathrm{H}$ NMR $\left(\mathrm{CDCl}_{3}, 300 \mathrm{MHz}\right): \delta=7.67(\mathrm{~d}, J=9.0 \mathrm{~Hz}, 1 \mathrm{H}), 7.94(\mathrm{~d}, J=9.0 \mathrm{~Hz}$, 1H), $8.07(\mathrm{~d}, J=8.4 \mathrm{~Hz}, 2 \mathrm{H}), 8.25(\mathrm{~d}, J=8.1 \mathrm{~Hz}, 2 \mathrm{H}), 10.14 \mathrm{ppm}(\mathrm{s}, 1 \mathrm{H})$.

4-(6-(4-(Diphenylamino)phenyl)pyridazin-3-yl)benzaldehyde (5a). Synthesized from 14 (180 mg; $0.823 \mathrm{mmol}$ ) and 4-(diphenylamino)phenylboronic acid 15 (286 mg; $0.988 \mathrm{mmol})$ following the general procedure A. Yield: $230 \mathrm{mg}(65 \%)$; yellow solid; $R_{\mathrm{f}}=0.4\left(\mathrm{SiO}_{2}\right.$; $\left.\mathrm{CH}_{2} \mathrm{Cl}_{2}\right)$; mp 216-217 ${ }^{\circ} \mathrm{C} ;{ }^{1} \mathrm{H}$ NMR $\left(\mathrm{CDCl}_{3}, 300 \mathrm{MHz}\right): \delta=7.03(\mathrm{t}, J=7.2 \mathrm{~Hz}, 2 \mathrm{H})$, 7.09-7.12 (m, 6H), 7.18-7.26 (m, 4H), $7.82(\mathrm{~d}, J=9.0 \mathrm{~Hz}, 1 \mathrm{H}), 7.87(\mathrm{~d}, J=9.0 \mathrm{~Hz}, 1 \mathrm{H})$, 7.95-7.98 (m, 4H), $8.24(\mathrm{~d}, J=8.1 \mathrm{~Hz}, 2 \mathrm{H}), 10.03 \mathrm{ppm}(\mathrm{s}, 1 \mathrm{H}) ;{ }^{13} \mathrm{C} \mathrm{NMR}\left(\mathrm{CDCl}_{3}, 75 \mathrm{MHz}\right)$ : $\delta=122.1,123.5,124.0,124.6,125.4,127.3,127.9,128.3,129.5,130.3,137.0,141.7,147.0$, 150.1, 155.7, 157.8, 191.8 ppm; HR-MALDI-MS (DHB): $\mathrm{m} / \mathrm{z}$ calculated for $\mathrm{C}_{29} \mathrm{H}_{22} \mathrm{~N}_{3} \mathrm{O}$ $[\mathrm{M}+\mathrm{H}]^{+} 428.17574$, found 428.17808 . 


\section{5-(4-(6-(4-(Diphenylamino)phenyl)pyridazin-3-yl)benzylidene)-4H-}

cyclopenta[c]thiophene-4,6(5H)-dione (1a). Synthesized from 5a (53 mg; $0.124 \mathrm{mmol})$ and 11 (38 mg; $0.248 \mathrm{mmol}$ ) following the general procedure B. Yield: $30 \mathrm{mg}$ (43\%); red solid; $R_{\mathrm{f}}=0.8\left(\mathrm{SiO}_{2} ; \mathrm{CH}_{2} \mathrm{Cl}_{2} / \mathrm{EtOAc} 10: 1\right) ; \mathrm{mp} 270-271{ }^{\circ} \mathrm{C} ;{ }^{1} \mathrm{H} \mathrm{NMR}\left(\mathrm{CDCl}_{3}, 300 \mathrm{MHz}\right): \delta=7.11$ (t, $J=7.2 \mathrm{~Hz}, 2 \mathrm{H}), 7.17-7.19(\mathrm{~m}, 6 \mathrm{H}), 7.29-7.34(\mathrm{~m}, 4 \mathrm{H}), 7.91(\mathrm{~d}, J=9.0 \mathrm{~Hz}, 1 \mathrm{H}), 7.93(\mathrm{~s}$, $1 \mathrm{H}), 7.98(\mathrm{~d}, J=9.0 \mathrm{~Hz}, 1 \mathrm{H}), 8.04-8.07(\mathrm{~m}, 4 \mathrm{H}), 8.31(\mathrm{~d}, J=8.4 \mathrm{~Hz}, 2 \mathrm{H}), 8.59 \mathrm{ppm}(\mathrm{d}, J=$ $8.7 \mathrm{~Hz}, 2 \mathrm{H}) ;{ }^{13} \mathrm{C} \mathrm{NMR}\left(\mathrm{CDCl}_{3}, 75 \mathrm{MHz}\right): \delta=122.3,123.3,123.9,124.3,125.3,125.9,126.0$, $126.9,127.9,128.6,129.5,134.2,134.8,137.4,140.3,145.6,147.1,147.3,150.0,155.8$, 157.6, 182.8 ppm; IR (ATR): $\quad v=1722,1674 \mathrm{~cm}^{-1}$; HR-MALDI-MS (DHB): $m / z$ calculated for $\mathrm{C}_{36} \mathrm{H}_{24} \mathrm{~N}_{3} \mathrm{O}_{2} \mathrm{~S}[\mathrm{M}+\mathrm{H}]^{+}$562.15837, found 562.15862.

4-(2-Chloropyrimidin-5-yl)- $N, N$-diphenylaniline (17). Synthesized from 16 (150 mg; $0.776 \mathrm{mmol})$ and $15(224 \mathrm{mg}$; $0.853 \mathrm{mmol})$ following the general procedure A. Yield: $180 \mathrm{mg}$ $(65 \%)$; yellowish solid; $R_{\mathrm{f}}=0.65\left(\mathrm{SiO}_{2} ; \mathrm{CH}_{2} \mathrm{Cl}_{2}\right) ; \mathrm{mp} 156-157{ }^{\circ} \mathrm{C} ;{ }^{1} \mathrm{H} \mathrm{NMR}\left(\mathrm{CDCl}_{3}\right.$, $300 \mathrm{MHz}): \delta=7.00-7.10(\mathrm{~m}, 8 \mathrm{H}), 7.19-7.25(\mathrm{~m}, 4 \mathrm{H}), 7.33(\mathrm{~d}, J=8.7 \mathrm{~Hz}, 2 \mathrm{H}), 8.71 \mathrm{ppm}(\mathrm{s}$, $2 \mathrm{H}) ;{ }^{13} \mathrm{C} \mathrm{NMR}\left(\mathrm{CDCl}_{3}, 75 \mathrm{MHz}\right): \delta=123.0,123.9,125.2,125.5,127.5,129.5,132.8,147.0$, 149.2, 156.8, 159.3 ppm; HRMS (ESI/ASAP, TOF): $m / z$ calculated for $\mathrm{C}_{22} \mathrm{H}_{16} \mathrm{~N}_{3} \mathrm{Cl} 357.1033$, found 357.1029 .

4-(5-(4-(Diphenylamino)phenyl)pyrimidin-2-yl)benzaldehyde (6a). Synthesized from 17 (150 mg; $0.419 \mathrm{mmol})$ and $12(79 \mathrm{mg} ; 0.524 \mathrm{mmol})$ following the general method A. Yield: $145 \mathrm{mg}(81 \%)$; yellow solid; $R_{\mathrm{f}}=0.9\left(\mathrm{SiO}_{2} ; \mathrm{CH}_{2} \mathrm{Cl}_{2} / \mathrm{EtOAc} 10: 1\right) ; \mathrm{mp} 236-237{ }^{\circ} \mathrm{C} .{ }^{1} \mathrm{H}$ NMR $\left(\mathrm{CDCl}_{3}, 300 \mathrm{MHz}\right): \delta=7.10(\mathrm{t}, J=7.2 \mathrm{~Hz}, 2 \mathrm{H}), 7.15-7.20(\mathrm{~m}, 6 \mathrm{H}), 7.26-7.34(\mathrm{~m}, 4 \mathrm{H}), 7.51$ $(\mathrm{d}, J=8.7 \mathrm{~Hz}, 2 \mathrm{H}), 8.02(\mathrm{~d}, J=8.4 \mathrm{~Hz}, 2 \mathrm{H}), 8.65(\mathrm{~d}, J=8.4 \mathrm{~Hz}, 2 \mathrm{H}), 9.04(\mathrm{~s}, 2 \mathrm{H}), 10.12 \mathrm{ppm}$ $(\mathrm{s}, 1 \mathrm{H}) ;{ }^{13} \mathrm{C} \mathrm{NMR}\left(\mathrm{CDCl}_{3}, 75 \mathrm{MHz}\right): \delta=123.1,123.8,125.1,126.9,127.5,128.5,129.5$, 
130.0, 132.0, 137.5, 42.9, 147.1, 149.0, 154.7 ppm; HRMS (ESI/ASAP, TOF): $\mathrm{m} / \mathrm{z}$ calculated for $\mathrm{C}_{29} \mathrm{H}_{22} \mathrm{~N}_{3} \mathrm{O} 428.1763$, found 428.1763 .

\section{5-(4-(5-(4-(Diphenylamino)phenyl)pyrimidin-2-yl)benzylidene)-4H-}

cyclopenta $[\boldsymbol{c}]$ thiophene-4,6(5H)-dione (2a). Synthesized from $\mathbf{6 a}(53 \mathrm{mg} ; 0.124 \mathrm{mmol})$ and 11 (38 mg; $0.248 \mathrm{mmol}$ ) following the general procedure B. Yield: $39 \mathrm{mg}$ (56\%); red solid; $R_{\mathrm{f}}=0.7\left(\mathrm{SiO}_{2} ; \mathrm{CH}_{2} \mathrm{Cl}_{2} / \mathrm{EtOAc} 10: 1\right) ; \operatorname{mp} 232-233{ }^{\circ} \mathrm{C} ;{ }^{1} \mathrm{H} \mathrm{NMR}\left(\mathrm{CDCl}_{3}, 300 \mathrm{MHz}\right): \delta=7.09$ $(\mathrm{t}, J=7.2 \mathrm{~Hz}, 2 \mathrm{H}), 7.15-7.20(\mathrm{~m}, 6 \mathrm{H}), 7.29-7.34(\mathrm{~m}, 4 \mathrm{H}), 7.52(\mathrm{~d}, J=8.7 \mathrm{~Hz}, 2 \mathrm{H}), 7.93(\mathrm{~s}$, $1 \mathrm{H}), 8.05(\mathrm{~s}, 2 \mathrm{H}), 8.56(\mathrm{~d}, J=8.7 \mathrm{~Hz}, 2 \mathrm{H}) 8.61(\mathrm{~d}, J=8.4 \mathrm{~Hz}, 2 \mathrm{H}), 9.04 \mathrm{ppm}(\mathrm{s}, 2 \mathrm{H})$; ${ }^{13} \mathrm{C} \mathrm{NMR}\left(\mathrm{CDCl}_{3}, 75 \mathrm{MHz}\right): \delta=123.1,123.8,125.1,125.8,125.9,127.1,127.4,128.2$, $129.5,131.8,134.6,134.7,137.3,141.5,145.6,147.2,147.4,147.6,148.9,154.6,161.7$, 182.1, 182.9 ppm; IR (ATR): $v=1721,1677 \mathrm{~cm}^{-1}$; HR-MALDI-MS (DHB): $m / z$ calculated for $\mathrm{C}_{36} \mathrm{H}_{24} \mathrm{~N}_{3} \mathrm{O}_{2} \mathrm{~S}[\mathrm{M}+\mathrm{H}]^{+}$562.15837, found 562.15885.

4-(2-Chloropyrimidin-5-yl)benzaldehyde (18). Synthesized from 16 (290 mg; $1.5 \mathrm{mmol}$ ) and 12 (247 mg; $1.65 \mathrm{mmol})$ following the general procedure A. Yield: $75 \mathrm{mg}$ (23\%); white solid; $R_{\mathrm{f}}=0.35\left(\mathrm{SiO}_{2} ; \mathrm{CH}_{2} \mathrm{Cl}_{2}\right) ; \mathrm{mp} 181-182{ }^{\circ} \mathrm{C} ;{ }^{1} \mathrm{H}$ NMR $\left(\mathrm{CDCl}_{3}, 300 \mathrm{MHz}\right): \delta=7.74(\mathrm{~d}$, $J=8.1 \mathrm{~Hz}, 2 \mathrm{H}), 8.04(\mathrm{~d}, J=8.1 \mathrm{~Hz}, 2 \mathrm{H}), 8.88(\mathrm{~s}, 2 \mathrm{H}), 10.10 \mathrm{ppm}(\mathrm{s}, 1 \mathrm{H}) ;{ }^{13} \mathrm{C} \mathrm{NMR}\left(\mathrm{CDCl}_{3}\right.$, $75 \mathrm{MHz}): \delta=127.6,130.7,131.8,136.7,138.7,157.6,161.3,191.2 \mathrm{ppm}$; Data similar to the literature. $^{16 \mathrm{a}}$

4-(2-(4-(Diphenylamino)phenyl)pyrimidin-5-yl)benzaldehyde (6b). Synthesized from 18 (60 mg; $0.274 \mathrm{mmol})$ and 15 (99 $\mathrm{mg} ; 0.343 \mathrm{mmol})$ following the general procedure A. Yield: $85 \mathrm{mg}(73 \%)$; yellow solid; $R_{\mathrm{f}}=0.9\left(\mathrm{SiO}_{2} ; \mathrm{CH}_{2} \mathrm{Cl}_{2} / \mathrm{EtAcO} 10: 1\right) ; \mathrm{mp} 240-241{ }^{\circ} \mathrm{C} ;{ }^{1} \mathrm{H} \mathrm{NMR}$ $\left(\mathrm{CDCl}_{3}, 300 \mathrm{MHz}\right): \delta=7.10-7.21(\mathrm{~m}, 8 \mathrm{H}), 7.28-7.36(\mathrm{~m}, 4 \mathrm{H}), 7.83(\mathrm{~d}, J=8.1 \mathrm{~Hz}, 2 \mathrm{H}), 8.06$ $(\mathrm{d}, J=8.4 \mathrm{~Hz}, 2 \mathrm{H}), 8.36(\mathrm{~d}, J=8.7 \mathrm{~Hz}, 2 \mathrm{H}), 9.03(\mathrm{~s}, 2 \mathrm{H}), 10.11 \mathrm{ppm}(\mathrm{s}, 1 \mathrm{H}) ;{ }^{13} \mathrm{C} \mathrm{NMR}$ $\left(\mathrm{CDCl}_{3}, 75 \mathrm{MHz}\right): \delta=121.7,123.9,125.4,127.1,129.40,129.44,129.9,130.7,136.1,140.7$ 
147.1, 150.7, 155.3, $164.1 \mathrm{ppm}$; HRMS (ESI/ASAP, TOF): $\mathrm{m} / \mathrm{z}$ calculated for $\mathrm{C}_{29} \mathrm{H}_{22} \mathrm{~N}_{3} \mathrm{O}$ 428.1763 , found 428.1763 .

\section{5-(4-(2-(4-(Diphenylamino)phenyl)pyrimidin-5-yl)benzylidene)-4H-}

cyclopenta[c]thiophene-4,6(5H)-dione (2b). Synthesized from $6 \mathrm{~b}(53 \mathrm{mg} ; 0.124 \mathrm{mmol})$ and 11 (38 mg; $0.248 \mathrm{mmol}$ ) following the general procedure B. Yield: $40 \mathrm{mg}$ (57\%); red solid; $R_{\mathrm{f}}=0.7\left(\mathrm{SiO}_{2} ; \mathrm{CH}_{2} \mathrm{Cl}_{2} / \mathrm{EtOAc} 10: 1\right) ; \mathrm{mp} 253{ }^{\circ} \mathrm{C} ;{ }^{1} \mathrm{H} \mathrm{NMR}\left(\mathrm{CDCl}_{3}, 300 \mathrm{MHz}\right): \delta=7.09-7.21$ (m, 8H), 7.28-7.35 (m, 4H), $7.80(\mathrm{~d}, J=8.1 \mathrm{~Hz}, 2 \mathrm{H}), 7.92(\mathrm{~s}, 1 \mathrm{H}), 8.07(\mathrm{~s}, 2 \mathrm{H}), 8.36(\mathrm{~d}$, $J=8.4 \mathrm{~Hz}, 2 \mathrm{H}) 8.58(\mathrm{~d}, J=8.1 \mathrm{~Hz}, 2 \mathrm{H}), 9.06 \mathrm{ppm}(\mathrm{s}, 2 \mathrm{H}) ;{ }^{13} \mathrm{C} \mathrm{NMR}\left(\mathrm{CDCl}_{3}, 75 \mathrm{MHz}\right): \delta=$ $121.9,124.0,125.5,126.1,126.2,126.8,129.5,129.6,130.2,133.2,135.3,137.5,139.3$, $145.8,147.2,147.3,147.5,150.8,155.3,164.1,182.9 \mathrm{ppm}$; IR (ATR): $v=1716,1673 \mathrm{~cm}^{-1}$; HR-MALDI-MS (DHB): $m / z$ calculated for $\mathrm{C}_{36} \mathrm{H}_{24} \mathrm{~N}_{3} \mathrm{O}_{2} \mathrm{~S} \quad[\mathrm{M}+\mathrm{H}]^{+}$562.15838, found 562.15687.

4'-Bromo- $N, N$-diphenyl-[1,1'-biphenyl]-4-amine (20). Synthesized from boronic acid 15 (318 mg; $1.1 \mathrm{mmol})$ and 1-bromo-4-iodobenzene $19(283 \mathrm{mg} ; 1 \mathrm{mmol})$ following the general method A. Yield: $365 \mathrm{mg}(91 \%)$; yellowish amorphous solid; $R_{\mathrm{f}}=0.85 \quad\left(\mathrm{SiO}_{2}\right.$; $\mathrm{CH}_{2} \mathrm{Cl}_{2} /$ hexane 1:2); mp 98-99 ${ }^{\circ} \mathrm{C} ;{ }^{1} \mathrm{H} \mathrm{NMR}\left(\mathrm{CDCl}_{3}, 300 \mathrm{MHz}\right): \delta=7.07(\mathrm{t}, J=7.2 \mathrm{~Hz}, 2 \mathrm{H})$, 7.14-7.17 (m, 6H), 7.24-7.32 (m, 4H), 7.43-7.46 (m, 4H), $7.56 \mathrm{ppm}(\mathrm{d}, J=8.7 \mathrm{~Hz}, 2 \mathrm{H})$. Data similar to the literature. ${ }^{36}$

4"-(Diphenylamino)-[1,1':4',1"-terphenyl]-4-carbaldehyde (7a). Synthesized from 20 (190 $\mathrm{mg}$; $0.475 \mathrm{mmol})$ and $12(89 \mathrm{mg} ; 0.593 \mathrm{mmol})$ following the general procedure A. Yield: $130 \mathrm{mg}(64 \%)$; yellow solid; $R_{\mathrm{f}}=0.8\left(\mathrm{SiO}_{2} ; \mathrm{CH}_{2} \mathrm{Cl}_{2} /\right.$ hexane $\left.2: 1\right) ; \mathrm{mp} 172-173{ }^{\circ} \mathrm{C} ;{ }^{1} \mathrm{H} \mathrm{NMR}$ $\left(\mathrm{CDCl}_{3}, 300 \mathrm{MHz} ; 25^{\circ} \mathrm{C}\right): \delta=7.00(\mathrm{t}, J=7.2 \mathrm{~Hz}, 2 \mathrm{H}), 7.09-7.11(\mathrm{~m}, 6 \mathrm{H}), 7.20-7.23(\mathrm{~m}$, 4H), $7.48(\mathrm{~d}, J=8.7 \mathrm{~Hz}, 2 \mathrm{H}), 7.65(\mathrm{~s} / \mathrm{m}, 4 \mathrm{H}), 7.75(\mathrm{~d}, J=8.4 \mathrm{~Hz}, 2 \mathrm{H}), 7.92(\mathrm{~d}, J=8.1 \mathrm{~Hz}$, 2H), $10.01 \mathrm{ppm}(\mathrm{s}, 1 \mathrm{H})$. Data similar to the literature. ${ }^{34}$ 


\section{5-((4"'-(Diphenylamino)-[1,1':4',1'-terphenyl]-4-yl)methylene)-4H-}

cyclopenta $[\boldsymbol{c}]$ thiophene-4,6(5H)-dione (3a). Synthesized from $7 \mathbf{a}(60 \mathrm{mg} ; 0.141 \mathrm{mmol})$ and 11 (43 mg; $0.282 \mathrm{mmol}$ ) following the general procedure B. Yield: $55 \mathrm{mg}$ (70\%); red solid; $R_{\mathrm{f}}=0.9\left(\mathrm{SiO}_{2} ; \mathrm{CH}_{2} \mathrm{Cl}_{2} / \mathrm{EtOAc} 10: 1\right) ; \mathrm{mp} 206{ }^{\circ} \mathrm{C} ;{ }^{1} \mathrm{H} \mathrm{NMR}\left(\mathrm{CDCl}_{3}, 300 \mathrm{MHz}\right): \delta=7.07(\mathrm{t}, J$ $=7.2 \mathrm{~Hz}, 2 \mathrm{H}), 7.16-7.19(\mathrm{~m}, 6 \mathrm{H}), 7.28-7.33(\mathrm{~m}, 4 \mathrm{H}), 7.55(\mathrm{~d}, J=8.4 \mathrm{~Hz}, 2 \mathrm{H}), 7.69-7.83(\mathrm{~m}$,

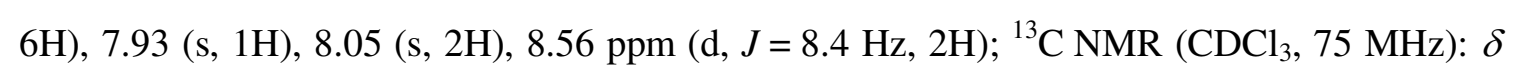
$=123.1,123.7,124.6,125.6,125.7,127.0,127.1,127.6,127.7,129.3,132.0,134.0,135.1$, $136.5,138.0,140.8,145.4,145.6,147.4,147.6,147.9,182.3,183.1 \mathrm{ppm}$; IR (ATR): $v=$ 1719, $1674 \mathrm{~cm}^{-1}$; HR-MALDI-MS (DHB): $\mathrm{m} / \mathrm{z}$ calculated for $\mathrm{C}_{38} \mathrm{H}_{26} \mathrm{NO}_{2} \mathrm{~S}[\mathrm{M}+\mathrm{H}]^{+}$ 560.16788 , found 560.16779 .

4-(5-Bromothiophen-2-yl)benzaldehyde (22). Synthesized from 21 (242 mg; $1.0 \mathrm{mmol})$ and 12 (150 mg; $1.0 \mathrm{mmol})$ following the general procedure A. The derivative $\mathbf{1 8}$ still contained small impurities after purification nevertheless it was used in next reaction step. Yield: $70 \mathrm{mg}$ (26\%); yellow solid; $R_{\mathrm{f}}=0.8\left(\mathrm{SiO}_{2} ; \mathrm{CH}_{2} \mathrm{Cl}_{2}\right) ; \mathrm{mp} 120-121{ }^{\circ} \mathrm{C} ;{ }^{1} \mathrm{H} \mathrm{NMR}\left(\mathrm{CDCl}_{3}, 300 \mathrm{MHz}\right)$ : $\delta=7.11(\mathrm{~d}, J=4.2 \mathrm{~Hz}, 1 \mathrm{H}), 7.23(\mathrm{~d}, J=4.2 \mathrm{~Hz}, 1 \mathrm{H}), 7.69(\mathrm{~d}, J=8.7 \mathrm{~Hz}, 2 \mathrm{H}), 7.91$ $(\mathrm{d}, J=8.7 \mathrm{~Hz}, 2 \mathrm{H}), 10.02 \mathrm{ppm}(\mathrm{s}, 1 \mathrm{H})$. Data similar to the literature. ${ }^{37}$

4-(5-(4-(Diphenylamino)phenyl)thiophen-2-yl)benzaldehyde (7d). Synthesized from 22 (60 mg; $0.225 \mathrm{mmol})$ and $\mathbf{1 5}(81 \mathrm{mg} ; 0.281 \mathrm{mmol})$ following the general procedure A. Yield: $68 \mathrm{mg}(70 \%)$; yellow-orange solid; $R_{\mathrm{f}}=0.75\left(\mathrm{SiO}_{2} ; \mathrm{CH}_{2} \mathrm{Cl}_{2}\right) ; \mathrm{mp} 159-160{ }^{\circ} \mathrm{C} .{ }^{1} \mathrm{H} \mathrm{NMR}$ $\left(\mathrm{CDCl}_{3}, 300 \mathrm{MHz}\right): \delta=7.06-7.17(\mathrm{~m}, 8 \mathrm{H}), 7.26-7.33(\mathrm{~m}, 5 \mathrm{H}), 7.46(\mathrm{~d}, J=3.9 \mathrm{~Hz}, 1 \mathrm{H}), 7.52$ $(\mathrm{d}, J=8.7 \mathrm{~Hz}, 2 \mathrm{H}), 7.78(\mathrm{~d}, J=8.4 \mathrm{~Hz}, 2 \mathrm{H}), 7.91(\mathrm{~d}, J=8.4 \mathrm{~Hz}, 2 \mathrm{H}), 10.01 \mathrm{ppm}(\mathrm{s}, 1 \mathrm{H}) ;{ }^{13} \mathrm{C}$ $\mathrm{NMR}\left(\mathrm{CDCl}_{3}, 75 \mathrm{MHz}\right): \delta=123.3,123.4,123.5,124.7,125.5,126.1,126.6,127.6,129.4$, 130.5, 134.9, 140.1, 140.7, 146.0, 147.3, 147.9, 191.4 ppm; HR-MALDI-MS (DHB): $\mathrm{m} / \mathrm{z}$ calculated for $\mathrm{C}_{29} \mathrm{H}_{21} \mathrm{NOS}[\mathrm{M}]^{+} 431.13384$, found 431.13324 . 


\section{5-(4-(5-(4-(Diphenylamino)phenyl)thiophen-2-yl)benzylidene)-4H-}

cyclopenta[c]thiophene-4,6(5H)-dione (3d). Synthesized from 7d (60 mg; $0.14 \mathrm{mmol})$ and 11 (42 mg; $0.28 \mathrm{mmol}$ ) following the general procedure B. Yield: $37 \mathrm{mg}$ (47\%); dark red solid; $R_{\mathrm{f}}=0.9\left(\mathrm{SiO}_{2} ; \mathrm{CH}_{2} \mathrm{Cl}_{2} / \mathrm{EtOAc} 10: 1\right) ; \operatorname{mp} 237{ }^{\circ} \mathrm{C} ;{ }^{1} \mathrm{H} \mathrm{NMR}\left(\mathrm{CDCl}_{3}, 300 \mathrm{MHz}\right): \delta=$ 7.06-7.17 (m, 8H), 7.27-7.33 (m, 5H), $7.49(\mathrm{~d}, J=3.9 \mathrm{~Hz}, 1 \mathrm{H}), 7.53(\mathrm{~d}, J=8.7 \mathrm{~Hz}, 2 \mathrm{H})$, $7.76(\mathrm{~d}, J=8.4 \mathrm{~Hz}, 2 \mathrm{H}), 7.86(\mathrm{~s}, 1 \mathrm{H}), 8.03(\mathrm{~s}, 2 \mathrm{H}), 8.50 \mathrm{ppm}(\mathrm{d}, J=8.4 \mathrm{~Hz}, 2 \mathrm{H}) ;{ }^{13} \mathrm{C} \mathrm{NMR}$ $\left(\mathrm{CDCl}_{3}, 75 \mathrm{MHz}\right): \delta=123.3,123.4,123.6,124.7,125.2,125.5,125.6,126.2,126.6,127.7$, 129.4, 131.8, 135.3, 136.1, 139.1, 141.2, 145.6, 146.1, 147.3, 147.6, 147.9, 182.4, 183.2 ppm; IR (ATR): $v=1719,1674 \mathrm{~cm}^{-1}$; HR-MALDI-MS (DHB): $\mathrm{m} / z$ calculated for $\mathrm{C}_{36} \mathrm{H}_{24} \mathrm{NO}_{2} \mathrm{~S}_{2}$ $[\mathrm{M}+\mathrm{H}]^{+}$566.12430, found 566.12290.

4-(6-Methylpyridazin-3-yl)- $N, N$-diphenylaniline (24). Synthesized from 23 (129 mg; $1 \mathrm{mmol})$ and $15(318 \mathrm{mg} ; 1.1 \mathrm{mmol})$ following the general procedure A. Yield: $240 \mathrm{mg}$ $(71 \%)$; yellowish solid; $R_{\mathrm{f}}=0.5\left(\mathrm{SiO}_{2} ; \mathrm{CH}_{2} \mathrm{Cl}_{2} / \mathrm{EtOAc} 10: 1\right) ; \mathrm{mp} 171-172{ }^{\circ} \mathrm{C} ;{ }^{1} \mathrm{H} \mathrm{NMR}$ $\left(\mathrm{CDCl}_{3}, 300 \mathrm{MHz}\right): \delta=2.64(\mathrm{~s}, 3 \mathrm{H}), 6.98(\mathrm{t}, J=7.2 \mathrm{~Hz}, 2 \mathrm{H}), 7.05-7.09(\mathrm{~m}, 6 \mathrm{H}), 7.17-7.25$ (m, 5H), $7.59(\mathrm{~d}, J=9.0 \mathrm{~Hz}, 1 \mathrm{H}), 7.85 \mathrm{ppm}(\mathrm{d}, J=8.7 \mathrm{~Hz}, 2 \mathrm{H}) ;{ }^{13} \mathrm{C} \mathrm{NMR}\left(\mathrm{CDCl}_{3}, 75 \mathrm{MHz}\right)$ : $\delta=122.7,123.6,125.1,127.7,129.4,129.6,147.3,149.5,156.8,157.8$ ppm; HR-MALDIMS (DHB): $m / z$ calculated for $\mathrm{C}_{23} \mathrm{H}_{19} \mathrm{~N}_{3}[\mathrm{M}]^{+} 337.15735$, found 337.15855 .

(E)-4-(2-(6-(4-(Diphenylamino)phenyl)pyridazin-3-yl)vinyl)benzaldehyde

(5b). Synthesized from 24 (200 mg; $0.593 \mathrm{mmol})$ and 25 (247 mg; $1.18 \mathrm{mmol})$ following the general procedures E and C. Yield: $100 \mathrm{mg}(37 \%)$; orange solid; $R_{\mathrm{f}}=0.9\left(\mathrm{SiO}_{2}\right.$; $\mathrm{CH}_{2} \mathrm{Cl}_{2}$ /EtOAc 10:1); mp 205-206 ${ }^{\circ} \mathrm{C} ;{ }^{1} \mathrm{H}$ NMR $\left(\mathrm{CDCl}_{3}, 300 \mathrm{MHz}\right): \delta=7.00-7.11(\mathrm{~m}, 8 \mathrm{H})$, 7.19-7.26 (m, 5H), $7.44(\mathrm{~d}, J=16.5 \mathrm{~Hz}, 1 \mathrm{H}), 7.58(\mathrm{~d}, J=9.0 \mathrm{~Hz}, 1 \mathrm{H}), 7.68-7.75(\mathrm{~m}, 3 \mathrm{H})$, $7.85(\mathrm{~d}, J=8.1 \mathrm{~Hz}, 2 \mathrm{H}), 7.94(\mathrm{~d}, J=8.7 \mathrm{~Hz}, 2 \mathrm{H}), 9.96 \mathrm{ppm}(\mathrm{s}, 1 \mathrm{H}) ;{ }^{13} \mathrm{C} \mathrm{NMR}\left(\mathrm{CDCl}_{3}\right.$, $75 \mathrm{MHz}): \delta=122.3,123.0,123.9,124.8,125.3,127.7,127.8,128.5,128.8,129.5,130.3$, 
132.6, 136.2, 142.1, 147.1, 149.9, 155.3, 157.2, 191.5 ppm; HR-MALDI-MS (DHB): $\mathrm{m} / \mathrm{z}$ calculated for $\mathrm{C}_{31} \mathrm{H}_{24} \mathrm{~N}_{3} \mathrm{O}[\mathrm{M}+\mathrm{H}]^{+} 454.19139$, found 454.19409.

\section{(E)-5-(4-(2-(6-(4-(Diphenylamino)phenyl)pyridazin-3-yl)vinyl)benzylidene)-4H-}

cyclopenta $[c]$ thiophene-4,6(5H)-dione (1b). Synthesized from $\mathbf{5 b}(60 \mathrm{mg} ; 0.132 \mathrm{mmol})$ and 11 (40 mg; $0.264 \mathrm{mmol}$ ) following the general procedure B. Yield: $30 \mathrm{mg}$ (38\%); red solid; $R_{\mathrm{f}}=0.8\left(\mathrm{SiO}_{2} ; \mathrm{CH}_{2} \mathrm{Cl}_{2} / \mathrm{EtOAc} 10: 1\right) ; \mathrm{mp}=291-292{ }^{\circ} \mathrm{C} ;{ }^{1} \mathrm{H} \mathrm{NMR}\left(\mathrm{CDCl}_{3}, 300 \mathrm{MHz}\right): \delta=$ 7.09-7.20 (m, 8H), 7.28-7.35 (m, 4H), $7.55(\mathrm{~d}, J=16.5 \mathrm{~Hz}, 1 \mathrm{H}), 7.68(\mathrm{~d}, J=9.0 \mathrm{~Hz}, 1 \mathrm{H})$, 7.75-7.83 (m, 4H), $7.88(\mathrm{~s}, 1 \mathrm{H}), 8.02-8.10(\mathrm{~m}, 4 \mathrm{H}), 8.51 \mathrm{ppm}(\mathrm{d}, J=8.1 \mathrm{~Hz}, 2 \mathrm{H}) ;{ }^{13} \mathrm{C} \mathrm{NMR}$ $\left(\mathrm{CDCl}_{3}, 75 \mathrm{MHz}\right): \delta=122.4,122.9,123.8,124.7,125.3,125.7,125.8,127.5,127.8,128.2$, $128.9,129.5,132.9,133.3,134.9,136.8,141.0,145.6,147.1,147.4,149.9,155.5,157.1$, 182.2, 183.0 ppm; IR (ATR): $v=1722,1672 \mathrm{~cm}^{-1}$; HR-MALDI-MS (DHB): $\mathrm{m} / z$ calculated for $\mathrm{C}_{38} \mathrm{H}_{26} \mathrm{~N}_{3} \mathrm{O}_{2} \mathrm{~S}[\mathrm{M}+\mathrm{H}]^{+}$588.17402, found 588.17463.

3-(4-(1,3-Dioxolan-2-yl)phenyl)-6-methylpyridazine (27). Synthesized in the first step from 23 (258 $\mathrm{mg} ; 2 \mathrm{mmol})$ and $12(375 \mathrm{mg} ; 2.5 \mathrm{mmol})$ following the general procedure A given aldehyde 26 in $85 \%$ yield. In the second step the purified aldehyde 26 (300 mg; $1.513 \mathrm{mmol}$ ) was undergone the protection of formyl group using ethylene glycol $(0.84 \mathrm{ml} ; 15.13 \mathrm{mmol})$ by following the general procedure D given desired acetal 27. Yield: $335 \mathrm{mg}$ (91\%); yellowish solid; mp $126-127{ }^{\circ} \mathrm{C} ;{ }^{1} \mathrm{H}$ NMR $\left(\mathrm{CDCl}_{3}, 300 \mathrm{MHz}\right): \delta=2.75$ (s, 3H), 4.04-4.10 (m, 2H), 4.11-4.17 (m, 2H), $5.89(\mathrm{~s}, 1 \mathrm{H}), 7.38(\mathrm{~d}, J=8.7 \mathrm{~Hz}, 1 \mathrm{H}), 7.62(\mathrm{~d}, J=8.4 \mathrm{~Hz}, 2 \mathrm{H})$, $7.75(\mathrm{~d}, J=8.7 \mathrm{~Hz}, 1 \mathrm{H}), 8.08 \mathrm{ppm}(\mathrm{d}, J=8.4 \mathrm{~Hz}, 2 \mathrm{H}) ;{ }^{13} \mathrm{C} \mathrm{NMR}\left(\mathrm{CDCl}_{3}, 75 \mathrm{MHz}\right): \delta=22.1$, 65.4, 103.3, 123.9, 126.9, 127.1, 127.2, 137.3, 139.5, 156.8, 158.7 ppm; HR-MALDI-MS (DHB): $m / z$ calculated for $\mathrm{C}_{14} \mathrm{H}_{15} \mathrm{~N}_{2} \mathrm{O}_{2}[\mathrm{M}+\mathrm{H}]^{+} 243.11280$, found 243.11405.

(E)-4-(6-(4-(Diphenylamino)styryl)pyridazin-3-yl)benzaldehyde (5c). Synthesized from 27 (242 $\mathrm{mg} ; 1.00 \mathrm{mmol})$ and $28(300 \mathrm{mg} ; 1.10 \mathrm{mmol})$ following the general procedures $\mathrm{E}$ and $\mathrm{C}$. 
Yield: $136 \mathrm{mg}$ (30\%); yellow-orange solid; $R_{\mathrm{f}}=0.7 \quad\left(\mathrm{SiO}_{2} ; \mathrm{CH}_{2} \mathrm{Cl}_{2} /\right.$ EtOAc $\left.20: 1\right) ; \mathrm{mp}$ 216-217 ${ }^{\circ} \mathrm{C} ;{ }^{1} \mathrm{H}$ NMR $\left(\mathrm{CDCl}_{3}, 300 \mathrm{MHz}\right): \delta=7.06-7.15(\mathrm{~m}, 8 \mathrm{H}), 7.26-7.32(\mathrm{~m}, 5 \mathrm{H}), 7.49$ $(\mathrm{d}, J=8.4 \mathrm{~Hz}, 2 \mathrm{H}), 7.70-7.75(\mathrm{~m}, 2 \mathrm{H}), 7.88(\mathrm{~d}, J=9.0 \mathrm{~Hz}, 1 \mathrm{H}), 8.04(\mathrm{~d}, J=8.1 \mathrm{~Hz}, 2 \mathrm{H})$, $8.30(\mathrm{~d}, J=8.1 \mathrm{~Hz}, 2 \mathrm{H}), 10.11 \mathrm{ppm}(\mathrm{s}, 1 \mathrm{H}) ;{ }^{13} \mathrm{C} \mathrm{NMR}\left(\mathrm{CDCl}_{3}, 75 \mathrm{MHz}\right): \delta=122.4,122.5$, $123.7,124.1,124.2,125.1,127.3,128.5,129.4,130.3,135.2,137.0,141.9,147.2,148.9$, 155.6, 157.7, 191.8 ppm; HR-MALDI-MS (DHB): $m / z$ calculated for $\mathrm{C}_{31} \mathrm{H}_{24} \mathrm{~N}_{3} \mathrm{O}[\mathrm{M}+\mathrm{H}]^{+}$ 454.19139, found 454.19392.

\section{(E)-5-(4-(6-(4-(Diphenylamino)styryl)pyridazin-3-yl)benzylidene)-4H-}

cyclopenta $[\boldsymbol{c}]$ thiophene-4,6(5H)-dione (1c). Synthesized from 5c $(60 \mathrm{mg} ; 0.132 \mathrm{mmol})$ and 11 (40 mg; $0.264 \mathrm{mmol}$ ) following the general procedure B. Yield: $39 \mathrm{mg}$ (50\%); red solid; $R_{\mathrm{f}}=0.8\left(\mathrm{SiO}_{2} ; \mathrm{CH}_{2} \mathrm{Cl}_{2} / \mathrm{EtOAc} 10: 1\right) ; \mathrm{mp} 260{ }^{\circ} \mathrm{C} ;{ }^{1} \mathrm{H} \mathrm{NMR}\left(\mathrm{CDCl}_{3}, 300 \mathrm{MHz}\right): \delta=7.07-7.17$ (m, 9H), 7.26-7.34 (m, 4H), $7.51(\mathrm{~d}, J=8.4 \mathrm{~Hz}, 2 \mathrm{H}), 7.68-7.77(\mathrm{~m}, 2 \mathrm{H}), 7.90-7.94(\mathrm{~m}, 2 \mathrm{H})$, $8.07(\mathrm{~s}, 2 \mathrm{H}), 8.29(\mathrm{~d}, J=8.4 \mathrm{~Hz}, 2 \mathrm{H}), 8.59 \mathrm{ppm}(\mathrm{d}, J=8.4 \mathrm{~Hz}, 2 \mathrm{H}) ;{ }^{13} \mathrm{C} \mathrm{NMR}\left(\mathrm{CDCl}_{3}, 75\right.$ $\mathrm{MHz}): \delta=122.5,123.7,124.0,124.2,125.0,125.1,125.9,126.0,126.9,128.4,129.4,134.1$, $134.8,135.0,137.4,140.4,145.6,147.2,147.3,148.9,155.7,157.5,182.1,182.8$ ppm; IR (ATR): $v=1722,1676 \mathrm{~cm}^{-1}$; HR-MALDI-MS (DHB): $\mathrm{m} / z$ calculated for $\mathrm{C}_{38} \mathrm{H}_{26} \mathrm{~N}_{3} \mathrm{O}_{2} \mathrm{~S}$ $[\mathrm{M}+\mathrm{H}]^{+}$588.17402, found 588.17297.

4-(2-Methylpyrimidin-5-yl)- $N, N$-diphenylaniline (30). Synthesized from 29 (173 mg; $1.00 \mathrm{mmol})$ and $15(318 \mathrm{mg} ; 1.10 \mathrm{mmol})$ following the general procedure A. Yield: $250 \mathrm{mg}$ (74\%); yellowish amorphous solid; $R_{\mathrm{f}}=0.25\left(\mathrm{SiO}_{2} ; \mathrm{CH}_{2} \mathrm{Cl}_{2} /\right.$ EtOAc 10:1); mp 116-117 ${ }^{\circ} \mathrm{C}$; ${ }^{1} \mathrm{H} \mathrm{NMR}\left(\mathrm{CDCl}_{3}, 300 \mathrm{MHz}\right): \delta=2.70(\mathrm{~s}, 3 \mathrm{H}), 6.99(\mathrm{t}, J=7.2 \mathrm{~Hz}, 2 \mathrm{H}), 7.02-7.10(\mathrm{~m}, 6 \mathrm{H})$, 7.19-7.24 (m, 4H), $7.34(\mathrm{~d}, J=8.4 \mathrm{~Hz}, 2 \mathrm{H}), 8.74 \mathrm{ppm}(\mathrm{s}, 2 \mathrm{H}) ;{ }^{13} \mathrm{C} \mathrm{NMR}\left(\mathrm{CDCl}_{3}, 75 \mathrm{MHz}\right)$ : $\delta=25.7,123.4,123.6,124.9,127.4,127.6,129.4,130.7,147.3,148.6,154.5,166.2$ ppm; HR-MALDI-MS (DHB): $m / z$ calculated for $\mathrm{C}_{23} \mathrm{H}_{19} \mathrm{~N}_{3}[\mathrm{M}]^{+}$337.15735, found 337.15941. 


\section{(E)-4-(2-(5-(4-(Diphenylamino)phenyl)pyrimidin-2-yl)vinyl)benzaldehyde}

(6c).

Synthesized from 30 (200 mg; $0.593 \mathrm{mmol})$ and 25 (247 mg; $1.186 \mathrm{mmol})$ following the general procedures $\mathrm{E}$ and C. Yield: $215 \mathrm{mg}(80 \%)$; yellow solid; $R_{\mathrm{f}}=0.85\left(\mathrm{SiO}_{2}\right.$; $\mathrm{CH}_{2} \mathrm{Cl}_{2}$ /EtOAc 10:1); mp 223-224 ${ }^{\circ} \mathrm{C} ;{ }^{1} \mathrm{H}$ NMR $\left(\mathrm{CDCl}_{3}, 300 \mathrm{MHz}\right): \delta=7.09(\mathrm{t}, J=7.2 \mathrm{~Hz}$, 2H), 7.14-7.19 (m, 6H), 7.26-7.33 (m, 4H), $7.41(\mathrm{~d}, J=16.2 \mathrm{~Hz}, 1 \mathrm{H}), 7.48(\mathrm{~d}, J=8.4 \mathrm{~Hz}$, 2H), $7.78(\mathrm{~d}, J=8.1 \mathrm{~Hz}, 2 \mathrm{H}), 7.92(\mathrm{~d}, J=8.1 \mathrm{~Hz}, 2 \mathrm{H}), 8.03(\mathrm{~d}, J=15.9 \mathrm{~Hz}, 1 \mathrm{H}), 8.94(\mathrm{~s}, 2 \mathrm{H})$, $10.03 \mathrm{ppm}(\mathrm{s}, 1 \mathrm{H}) ;{ }^{13} \mathrm{C} \mathrm{NMR}\left(\mathrm{CDCl}_{3}, 75 \mathrm{MHz}\right): \delta=123.2,123.8,125.1,127.1,127.4,128.0$, $129.5,130.2,130.5,131.3,135.9,136.3,142.1,147.2,148.9,154.4,162.3,191.6$ ppm; HRMALDI-MS (DHB): $\mathrm{m} / z$ calculated for $\mathrm{C}_{31} \mathrm{H}_{23} \mathrm{~N}_{3} \mathrm{O}[\mathrm{M}]^{+} 453.18356$, found 453.18608 .

(E)-5-(4-(2-(5-(4-(Diphenylamino)phenyl)pyrimidin-2-yl)vinyl)benzylidene)-4H-

cyclopenta $[c]$ thiophene-4,6(5H)-dione $(2 \mathrm{c})$. Synthesized from $\mathbf{6 c}(60 \mathrm{mg} ; 0.132 \mathrm{mmol})$ and 11 (40 mg; $0.264 \mathrm{mmol}$ ) following the general procedure B. Yield: $51 \mathrm{mg}(65 \%)$; red solid; $R_{\mathrm{f}}=0.8\left(\mathrm{SiO}_{2} ; \mathrm{CH}_{2} \mathrm{Cl}_{2} / \mathrm{EtOAc} 10: 1\right) ; \mathrm{mp} 275-276{ }^{\circ} \mathrm{C} ;{ }^{1} \mathrm{H} \mathrm{NMR}\left(\mathrm{CDCl}_{3}, 300 \mathrm{MHz}\right): \delta=$ 7.06-7.19 (m, 8H), 7.26-7.33 (m, 4H), $7.43(\mathrm{~d}, J=16.5 \mathrm{~Hz}, 1 \mathrm{H}), 7.48(\mathrm{~d}, J=8.7 \mathrm{~Hz}, 2 \mathrm{H})$, $7.75(\mathrm{~d}, J=7.6 \mathrm{~Hz}, 2 \mathrm{H}), 7.86(\mathrm{~s}, 1 \mathrm{H}), 8.00-8.05(\mathrm{~m}, 3 \mathrm{H}), 8.47(\mathrm{~d}, J=8.1 \mathrm{~Hz}, 2 \mathrm{H}), 8.94 \mathrm{ppm}$ $(\mathrm{s}, 2 \mathrm{H}) ;{ }^{13} \mathrm{C} \mathrm{NMR}\left(\mathrm{CDCl}_{3}, 75 \mathrm{MHz}\right): \delta=123.2,123.7,125.0,125.7,125.8,127.2,127.4$, $127.8,129.5,130.2,131.1,133.5,134.9,136.2,136.8,141.0,145.6,147.2,147.4,148.8$, 154.4, 162.4, 183.0 ppm; IR (ATR): $v=1719,1671 \mathrm{~cm}^{-1} ;$ HR-MALDI-MS (DHB): $\mathrm{m} / \mathrm{z}$ calculated for $\mathrm{C}_{38} \mathrm{H}_{26} \mathrm{~N}_{3} \mathrm{O}_{2} \mathrm{~S}[\mathrm{M}+\mathrm{H}]^{+}$588.17402, found 588.17441.

4-(2-Methylpyrimidin-5-yl)benzaldehyde (31). Synthesized from 29 (346 mg; 2 mmol) and $12(375 \mathrm{mg} ; 2.5 \mathrm{mmol})$ following the general procedure A. Yield: $321 \mathrm{mg}(81 \%)$; white solid; $R_{\mathrm{f}}=0.8\left(\mathrm{SiO}_{2} ; \mathrm{CH}_{2} \mathrm{Cl}_{2} / \mathrm{EtOAc} 10: 1\right) ; \mathrm{mp} 192-193{ }^{\circ} \mathrm{C} ;{ }^{1} \mathrm{H} \mathrm{NMR}\left(\mathrm{CDCl}_{3}, 300 \mathrm{MHz}\right): \delta=$ $2.81(\mathrm{~s}, 3 \mathrm{H}), 7.74(\mathrm{~d}, J=8.1 \mathrm{~Hz}, 2 \mathrm{H}), 8.02(\mathrm{~d}, J=8.1 \mathrm{~Hz}, 2 \mathrm{H}), 8.90(\mathrm{~s}, 2 \mathrm{H}), 10.09 \mathrm{ppm}(\mathrm{s}$, $1 \mathrm{H}) ;{ }^{13} \mathrm{C} \mathrm{NMR}\left(\mathrm{CDCl}_{3}, 75 \mathrm{MHz}\right): \delta=25.8,127.4,129.9,130.6,136.2,140.4,155.1,168.1$, 
191.5 ppm; HR-MALDI-MS (DHB): $\mathrm{m} / z$ calculated for $\mathrm{C}_{12} \mathrm{H}_{11} \mathrm{~N}_{2} \mathrm{O}[\mathrm{M}+\mathrm{H}]^{+} 199.08659$, found 199.08707.

5-(4-(1,3-Dioxolan-2-yl)phenyl)-2-methylpyrimidine (32). Synthesized from 31 (300 mg; $1.513 \mathrm{mmol})$ and ethylene glycol $(0.84 \mathrm{ml} ; 15.13 \mathrm{mmol})$ following the general procedure D. Yield: $310 \mathrm{mg}(85 \%)$; yellowish solid; mp 132-133 ${ }^{\circ} \mathrm{C} ;{ }^{1} \mathrm{H} \mathrm{NMR}\left(\mathrm{CDCl}_{3}, 300 \mathrm{MHz}\right)$ : $\delta=2.72(\mathrm{~s}, 3 \mathrm{H}), 3.98-4.04(\mathrm{~m}, 2 \mathrm{H}), 4.05-4.11(\mathrm{~m}, 2 \mathrm{H}), 5.81(\mathrm{~s}, 1 \mathrm{H}), 7.51(\mathrm{~d}, J=8.1 \mathrm{~Hz}$, 2H), $7.56(\mathrm{~d}, J=8.1 \mathrm{~Hz}, 2 \mathrm{H}), 8.78 \mathrm{ppm}(\mathrm{s}, 2 \mathrm{H}) ;{ }^{13} \mathrm{C} \mathrm{NMR}\left(\mathrm{CDCl}_{3}, 75 \mathrm{MHz}\right): \delta=25.7,65.4$, 103.2, 126.8, 127.5, 130.8, 135.4, 138.6, 155.0, 167.1 ppm; HR-MALDI-MS (DHB): $\mathrm{m} / \mathrm{z}$ calculated for $\mathrm{C}_{14} \mathrm{H}_{15} \mathrm{~N}_{2} \mathrm{O}_{2}[\mathrm{M}+\mathrm{H}]^{+}$243.11280, found 243.11348 .

(E)-4-(2-(4-(Diphenylamino)styryl)pyrimidin-5-yl)benzaldehyde (6d). Synthesized from 32 (280 mg; $1.16 \mathrm{mmol})$ and 28 (316 $\mathrm{mg} ; 1.44 \mathrm{mmol})$ following the general procedures $\mathrm{E}$ and C. Yield: $285 \mathrm{mg}$ (54\%); orange solid; $R_{\mathrm{f}}=0.85\left(\mathrm{SiO}_{2} ; \mathrm{CH}_{2} \mathrm{Cl}_{2} / \mathrm{EtOAc} 10: 1\right) ; \mathrm{mp} 245-246$ ${ }^{\circ} \mathrm{C} ;{ }^{1} \mathrm{H}$ NMR $\left(\mathrm{CDCl}_{3}, 300 \mathrm{MHz}\right): \delta=7.06-7.22(\mathrm{~m}, 9 \mathrm{H}), 7.28-7.34(\mathrm{~m}, 4 \mathrm{H}), 7.53(\mathrm{~d}$, $J=8.4 \mathrm{~Hz}, 2 \mathrm{H}), 7.80(\mathrm{~d}, J=8.1 \mathrm{~Hz}, 2 \mathrm{H}), 8.00-8.06 \quad(\mathrm{~m}, 3 \mathrm{H}), 8.98(\mathrm{~s}, 2 \mathrm{H}), 10.11 \mathrm{ppm}(\mathrm{s}$, $1 \mathrm{H}) ;{ }^{13} \mathrm{C} \mathrm{NMR}\left(\mathrm{CDCl}_{3}, 75 \mathrm{MHz}\right): \delta=122.3,123.7,124.4,125.2,127.1,128.8,129.2,129.3$, 129.4, 130.7, 136.1, 138.6, 140.6, 147.1, 149.1, 155.2, 164.9, 191.5 ppm; HR-MALDI-MS (DHB): $m / z$ calculated for $\mathrm{C}_{31} \mathrm{H}_{23} \mathrm{~N}_{3} \mathrm{O}[\mathrm{M}]^{+} 453.18356$, found 453.18421 .

\section{(E)-5-(4-(2-(4-(Diphenylamino)styryl)pyrimidin-5-yl)benzylidene)-4H-}

cyclopenta $[c]$ thiophene-4,6(5H)-dione (2d). Synthesized from $\mathbf{6 d}(60 \mathrm{mg} ; 0.132 \mathrm{mmol})$ and 11 (40 mg; $0.264 \mathrm{mmol}$ ) following the general procedure B. Yield: $32 \mathrm{mg}$ (41\%); red solid; $R_{\mathrm{f}}=0.8\left(\mathrm{SiO}_{2} ; \mathrm{CH}_{2} \mathrm{Cl}_{2} / \mathrm{EtOAc} 10: 1\right) ; \mathrm{mp}=302-303{ }^{\circ} \mathrm{C} ;{ }^{1} \mathrm{H} \mathrm{NMR}\left(\mathrm{CDCl}_{3}, 300 \mathrm{MHz}\right): \delta=$ $7.05-7.20(\mathrm{~m}, 9 \mathrm{H}), 7.26-7.32(\mathrm{~m}, 4 \mathrm{H}), 7.51(\mathrm{~d}, J=8.4 \mathrm{~Hz}, 2 \mathrm{H}), 7.77(\mathrm{~d}, J=8.4 \mathrm{~Hz}, 2 \mathrm{H})$, $7.90(\mathrm{~s}, 1 \mathrm{H}), 8.00(\mathrm{~d}, J=16.2 \mathrm{~Hz}, 1 \mathrm{H}), 8.06(\mathrm{~s}, 2 \mathrm{H}), 8.56(\mathrm{~d}, J=8.4 \mathrm{~Hz}, 2 \mathrm{H}), 8.99 \mathrm{ppm}(\mathrm{s}$, $2 \mathrm{H}) ;{ }^{13} \mathrm{C} \mathrm{NMR}\left(\mathrm{CDCl}_{3}, 75 \mathrm{MHz}\right): \delta=122.3,123.7,124.5,125.2,125.9,126.1,126.6,128.8$, 
$129.3,129.4,133.1,135.1,137.3,138.5,139.0,145.6,147.0,147.2,147.3,149.1,155.1$, 164.8, 182.1, 182.8 ppm; IR (ATR): $v=1720,1680 \mathrm{~cm}^{-1}$; HR-MALDI-MS (DHB): $\mathrm{m} / \mathrm{z}$ calculated for $\mathrm{C}_{38} \mathrm{H}_{26} \mathrm{~N}_{3} \mathrm{O}_{2} \mathrm{~S}[\mathrm{M}+\mathrm{H}]^{+}$588.17402, found 588.17429.

(E)-4-(4-Bromostyryl)benzaldehyde (35). Synthesized from 34 (307 mg; $1 \mathrm{mmol}$ ) and 25 (219 mg; $1.05 \mathrm{mmol}$ ) following the general procedures F and C. Yield: $100 \mathrm{mg}$ (35\%); white solid; $R_{\mathrm{f}}=0.75\left(\mathrm{SiO}_{2} ; \mathrm{CH}_{2} \mathrm{Cl}_{2}\right) ; \mathrm{mp} 150-151^{\circ} \mathrm{C} ;{ }^{1} \mathrm{H}$ NMR $\left(\mathrm{CDCl}_{3}, 300 \mathrm{MHz}\right): \delta=7.11(\mathrm{~d}$, $J=16.5 \mathrm{~Hz}, 1 \mathrm{H}), 7.19(\mathrm{~d}, J=16.5 \mathrm{~Hz}, 1 \mathrm{H}), 7.40(\mathrm{~d}, J=8.4 \mathrm{~Hz}, 2 \mathrm{H}), 7.51(\mathrm{~d}, J=8.4 \mathrm{~Hz}, 2 \mathrm{H})$, $7.64(\mathrm{~d}, J=8.1 \mathrm{~Hz}, 2 \mathrm{H}), 7.87(\mathrm{~d}, J=8.4 \mathrm{~Hz}, 2 \mathrm{H}), 10.00 \mathrm{ppm}(\mathrm{s}, 2 \mathrm{H})$. Data similar to the literature. $^{38}$

(E)-4-(2-(4'-(Diphenylamino)-[1,1'-biphenyl]-4-yl)vinyl)benzaldehyde (7b). Synthesized from 35 (85 mg; $0.296 \mathrm{mmol})$ and $15(107 \mathrm{mg} ; 0.370 \mathrm{mmol})$ following the general procedure A. Yield: $95 \mathrm{mg}(71 \%)$; yellow solid; $R_{\mathrm{f}}=0.85\left(\mathrm{SiO}_{2} ; \mathrm{CH}_{2} \mathrm{Cl}_{2}\right) ; \mathrm{mp} 212-213{ }^{\circ} \mathrm{C} ;{ }^{1} \mathrm{H}$ NMR $\left(\mathrm{CDCl}_{3}, 300 \mathrm{MHz}\right): \delta=7.05(\mathrm{t}, J=7.2 \mathrm{~Hz}, 2 \mathrm{H}), 7.13-7.20(\mathrm{~m}, 7 \mathrm{H}), 7.26-7.33(\mathrm{~m}, 5 \mathrm{H}), 7.51$ $(\mathrm{d}, J=8.7 \mathrm{~Hz}, 2 \mathrm{H}), 7.61(\mathrm{~s} / \mathrm{m}, 4 \mathrm{H}), 7.67(\mathrm{~d}, J=8.1 \mathrm{~Hz}, 2 \mathrm{H}), 7.88(\mathrm{~d}, J=8.1 \mathrm{~Hz}, 2 \mathrm{H}), 10.00$ $\operatorname{ppm}(\mathrm{s}, 1 \mathrm{H}) ;{ }^{13} \mathrm{C} \mathrm{NMR}\left(\mathrm{CDCl}_{3}, 75 \mathrm{MHz}\right): \delta=123.1,123.7,124.6,126.9,127.0,127.4,127.6$, 129.3 130.3 131.8, 134.1, 135.1, 135.3, 140.7, 143.5, 147.5, 147.6, 191.6 ppm; HR-MALDIMS (DHB): $m / z$ calculated for $\mathrm{C}_{33} \mathrm{H}_{25} \mathrm{NO}[\mathrm{M}]^{+} 451.19307$, found 451.19480 .

(E)-5-(4-(2-(4'-(Diphenylamino)-[1,1'-biphenyl]-4-yl)vinyl)benzylidene)-4H-

cyclopenta $[\boldsymbol{c}]$ thiophene-4,6(5H)-dione (3b). Synthesized from $7 \mathbf{b}(60 \mathrm{mg} ; 0.133 \mathrm{mmol})$ and 11 (40 mg; $0.266 \mathrm{mmol}$ ) following the general procedure B. Yield: $45 \mathrm{mg}$ (58 \%); red solid; $R_{\mathrm{f}}=0.9\left(\mathrm{SiO}_{2} ; \mathrm{CH}_{2} \mathrm{Cl}_{2} / \mathrm{EtOAc} 10: 1\right) ; \mathrm{mp} 279-280{ }^{\circ} \mathrm{C} ;{ }^{1} \mathrm{H} \mathrm{NMR}\left(\mathrm{CDCl}_{3}, 300 \mathrm{MHz}\right): \delta=7.07$ $(\mathrm{t}, J=6.9 \mathrm{~Hz}, 2 \mathrm{H}), 7.15-7.37(\mathrm{~m}, 12 \mathrm{H}), 7.53(\mathrm{~d}, J=7.8 \mathrm{~Hz}, 2 \mathrm{H}), 7.63-7.68(\mathrm{~m}, 6 \mathrm{H}), 7.87(\mathrm{~s}$, 1H), $8.03(\mathrm{~s}, 2 \mathrm{H}), 8.49 \mathrm{ppm}(\mathrm{d}, J=7.5 \mathrm{~Hz}, 2 \mathrm{H}) ;{ }^{13} \mathrm{C} \mathrm{NMR}\left(\mathrm{CDCl}_{3}, 75 \mathrm{MHz}\right): \delta=123.1$, $123.7,124.6,125.5,125.6,126.7,126.9,127.4,127.5,127.6,129.3,131.8,132.3,134.1$, 
135.1, 135.2, 140.7, 142.6, 145.6, 147.4, 147.5, 147.6, 147.8, 183.1, 183.2 ppm; IR (ATR): $v$ $=1719,1667 \mathrm{~cm}^{-1}$; HR-MALDI-MS (DHB): $\mathrm{m} / \mathrm{z}$ calculated for $\mathrm{C}_{40} \mathrm{H}_{28} \mathrm{NO}_{2} \mathrm{~S}[\mathrm{M}+\mathrm{H}]^{+}$ 586.18353, found 586.18154.

(E)-4-(4-Bromostyryl)- $N, N$-diphenylaniline (36). Synthesized from 34 (307 mg; 1 mmol) and 28 (287 mg; $1.05 \mathrm{mmol}$ ) following the general procedure F. Yield: $210 \mathrm{mg}$ (49\%);

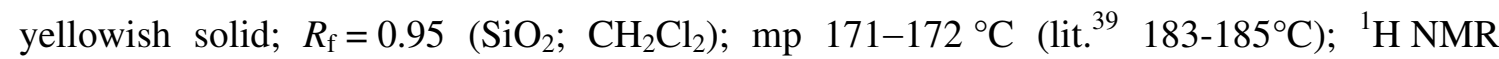
$\left(\mathrm{CDCl}_{3}, 300 \mathrm{MHz}\right): \delta=6.93(\mathrm{~d}, J=16.2 \mathrm{~Hz}, 1 \mathrm{H}), 7.04-7.14(\mathrm{~m}, 8 \mathrm{H}), 7.26-7.31(\mathrm{~m}, 5 \mathrm{H})$, $7.37(\mathrm{~d}, J=6.9 \mathrm{~Hz}, 2 \mathrm{H}), 7.39(\mathrm{~d}, J=6.9 \mathrm{~Hz}, 2 \mathrm{H}), 7.48 \mathrm{ppm}(\mathrm{d}, J=8.4 \mathrm{~Hz}, 2 \mathrm{H})$. Data similar to the literature. ${ }^{40}$

(E)-4'-(4-(Diphenylamino)styryl)-[1,1'-biphenyl]-4-carbaldehyde (7c). Synthesized from $36(150 \mathrm{mg} ; 0.352 \mathrm{mmol})$ and $12(66 \mathrm{mg} ; 0.440 \mathrm{mmol})$ following the general procedure A. Yield: $90 \mathrm{mg}(57 \%)$; yellow solid; $R_{\mathrm{f}}=0.85\left(\mathrm{SiO}_{2} ; \mathrm{CH}_{2} \mathrm{Cl}_{2}\right) ; \mathrm{mp} 205-206{ }^{\circ} \mathrm{C} ;{ }^{1} \mathrm{H}$ NMR $\left(\mathrm{CDCl}_{3}, 300 \mathrm{MHz}\right): \delta=7.02-7.10(\mathrm{~m}, 5 \mathrm{H}), 7.13-7.19(\mathrm{~m}, 4 \mathrm{H}), 7.27-7.32(\mathrm{~m}, 5 \mathrm{H}), 7.43(\mathrm{~d}$, $J=8.7 \mathrm{~Hz}, 2 \mathrm{H}), 7.62(\mathrm{~d}, J=8.7 \mathrm{~Hz}, 2 \mathrm{H}), 7.67(\mathrm{~d}, J=8.4 \mathrm{~Hz}, 2 \mathrm{H}), 7.80(\mathrm{~d}, J=8.1 \mathrm{~Hz}, 2 \mathrm{H})$, $7.98(\mathrm{~d}, J=8.1 \mathrm{~Hz}, 2 \mathrm{H}), 10.08 \mathrm{ppm}(\mathrm{s}, 1 \mathrm{H}) ;{ }^{13} \mathrm{C} \mathrm{NMR}\left(\mathrm{CDCl}_{3}, 75 \mathrm{MHz}\right): \delta=123.4,124.6$, $126.0,126.9,127.3,127.5,127.6,129.1,129.3,130.3,131.1,135.1,138.0,138.3,146.7$, 147.5, 147.7, 191.9 ppm; HR-MALDI-MS (DHB): $\mathrm{m} / z$ calculated for $\mathrm{C}_{33} \mathrm{H}_{25} \mathrm{NO}[\mathrm{M}]^{+}$ 451.19307, found 451.19540.

\section{(E)-5-((4'-(4-(Diphenylamino)styryl)-[1,1'-biphenyl]-4-yl)methylene)-4H-}

cyclopenta[c]thiophene-4,6(5H)-dione (3c). Synthesized from 7c $(60 \mathrm{mg} ; 0.133 \mathrm{mmol})$ and 11 (40 mg; $0.266 \mathrm{mmol}$ ) following the general procedure B. Yield: $35 \mathrm{mg}$ (45\%); red solid; $R_{\mathrm{f}}=0.85\left(\mathrm{SiO}_{2} ; \mathrm{CH}_{2} \mathrm{Cl}_{2} / \mathrm{EtOAc} 10: 1\right) ; \mathrm{mp} \mathrm{230-231}{ }^{\circ} \mathrm{C} ;{ }^{1} \mathrm{H} \mathrm{NMR}\left(\mathrm{CDCl}_{3}, 300 \mathrm{MHz}\right): \delta=$ 7.04-7.19 (m, 9H), 7.28-7.32 (m, 5H), $7.44(\mathrm{~d}, J=8.7 \mathrm{~Hz}, 2 \mathrm{H}), 7.62(\mathrm{~d}, J=8.1 \mathrm{~Hz}, 2 \mathrm{H})$, $7.71(\mathrm{~d}, J=8.1 \mathrm{~Hz}, 2 \mathrm{H}), 7.80(\mathrm{~d}, J=8.4 \mathrm{~Hz}, 2 \mathrm{H}), 7.93(\mathrm{~s}, 1 \mathrm{H}), 8.05(\mathrm{~s}, 2 \mathrm{H}), 8.55 \mathrm{ppm}(\mathrm{d}, J=$ 
$8.4 \mathrm{~Hz}, 2 \mathrm{H}) ;{ }^{13} \mathrm{C} \mathrm{NMR}\left(\mathrm{CDCl}_{3}, 75 \mathrm{MHz}\right): \delta=123.0,123.4,124.6,125.6,125.7,126.1,126.9$, $127.0,127.5,129.1,129.3,131.2,132.0,135.1,136.5,138.0,138.3,145.4,145.6,147.4$, 147.5, 147.6, 147.9, 183.2 ppm; IR (ATR): $v=1717,1673 \mathrm{~cm}^{-1}$. HR-MALDI-MS (DHB): $m / z$ calculated for $\mathrm{C}_{40} \mathrm{H}_{28} \mathrm{NO}_{2} \mathrm{~S}[\mathrm{M}+\mathrm{H}]^{+}$586.18353, found 586.18131.

\section{Acknowledgement}

M. K. and F. B. are indebted to the Ministry of Education, Youth and Sports of the Czech Republic (specific research).

\section{Associated content}

Supporting information: X-ray analysis experimental details and X-ray data of compound 3d (CIF), representative cyclic voltammetry curves, absorption data and curves in various solvents for compounds $\mathbf{1 - 4}$, emission spectra of $\mathbf{5 a}, \mathbf{6 a}-\mathbf{b}, \mathbf{7 a}$ and $\mathbf{7 d}$, emission maxima $\left(\lambda_{\mathrm{em}}\right)$ vs. $E_{T}(30)$ for selected aldehydes, fluorescence color changes of $\mathbf{6 b}$ in various solvents, DSC curves of chromophores 1-4, Cartesian coordinates, total energies and HOMO-LUMO localizations for compounds $\mathbf{1 - 4}$, correlation between experimental (absorption, electrochemical and EFISH NLO) and calculated data, ${ }^{1} \mathrm{H}$ and ${ }^{13} \mathrm{C}$ NMR spectra (PDF).

\footnotetext{
${ }^{1}$ Andreu, R.; Galán, E.; Orduna, J.; Villacampa, B.; Alicante, R.; López-Navarrete, J. T.; Casado, J.; Garín, J. Chem. Eur. J. 2011, 17, 826-838.

2 (a) Li, C.; Plamont, M.-A.; Aujard, I.; Le Saux, T.; Jullien, L.; Gautier, A. Org. Biomol. Chem. 2016, 14, 9253-9261. (b) Shaya, J.; Fontaine-Vive, F.; Michel, B. Y.; Burger, A. Chem. Eur. J. 2016, 22, 10627-10637. (c) Watanabe, H.; Ono, M.; Saji, H. Chem. Commun. 2015, 51, 17124-12127.

${ }^{3}$ (a) Lin, Y.; Li, Y.; Zhang, X. Chem. Soc. Rev. 2012, 41, 4245-4272. (b) Hagfeldt, A.; Boschloo, G.; Sun, L.; Kloo, L.; Pettersson, H. Chem. Rev. 2012, 110, 6595-6663.
} 
${ }^{4}$ (a) Raposo, M. M. M. Herbivo, C.; Hugues, V.; Clermont, G.; Castro, M. C. R.; Comel, A.; Blanchard-Desce, M. Eur. J. Org. Chem. 2016, 5263-5273. (b) Morales, A. R.; Frazer, A.; Woodward, A. W.; Ahn-White, H. Y.; Fonari, A.; Tongwa, P.; Timofeeva, T.; Belfield, K. D. J. Org. Chem. 2013, 78, 1014-1025.

${ }^{5}$ (a) Verbiest, T.; Houbrechts, S.; Kauranen, M.; Clays, K.; Persoons, A. J. Mater. Chem. 1997, 7, 2175-2189. (b) Luo, J.; Hua, J.; Qin, J.; Cheng, J.; Shen, Y.; Lu, Z.; Wang, P.; Ye, C. Chem. Commun. 2001, 171-172. (c) Colombo, A.; Dragonetti, C.; Mariotto, D.; Righetto, S.; Griffini, G.; Turri, S.; Akdas-Kilig, H.; Fillaut, J.-L.; Amar, A.; Boucekkine, A.; Katan, C. Dalton Trans. 2016, 45, 11052-11060. (d) Gong, W.; Li, Q.; Li, Z.; Lu, C.; Zhu, J.; Li, S.; Yang, J.; Cui, Y.; Qin, J. J. Phys. Chem. B 2006, 110, 10241-10247.

${ }^{6}$ (a) Taniuchi, T.; Okadaand, S.; Nakanishi, H. Appl. Phys. Lett. 2004, 95, 5984-5988. (b) Taniuchi, T.; Ikeda, S.; Okada, S.; Nakanishi, H. Jpn J. Appl. Phys. 2005, 44, L652-L654. (c) Schneider, A.; Neis, M.; Stillhart, M.; Ruiz, B.; Khan, R. U. A.; Gunter, P. J. Opt. Soc. Am. B, 2006, 23, 1822-1835. (d) Schneider, A.; Stillhart M.; Günter, P. Opt. Express 2006, 14, 53765384. (e) Yang, Z.; Mutter, L.; Stillhart, M.; Ruiz, B.; Aravazhi, S.; Jazbinsek, M.; Schneider, A.; Gramlich, V.; Gunter, P. Adv. Funct. Mater. 2007, 17, 2018-2023.

${ }^{7}$ (a) Bureš, F. RSC Adv. 2014, 4, 58826-58851. (b) Moreno-Yruela, C.; Garín, J.; Orduna, S.; Quintero, E.; López Navarrete, J. T.; Diosdado, B. E.; Villacampa, B.; Casado, J.; Andreu, R. J. Org. Chem. 2015, 80, 12115-12128. (c) Achelle, S.; Kahlal, S.; Barsella, A.; Saillard, J.-Y.; Che, X.; Vallet, J.; Bureš, F.; Caro, B.; Robin-le Guen, F. Dyes Pigm. 2015, 113, 562-570.

${ }^{8}$ (a) Bureš, F.; Schweizer, W. B.; May, J. C.; Boudon, C.; Gisselbrecht, J.-P.; Gross, M.; Biaggio, I.; Diederich, F. Chem. Eur. J. 2007, 13, 5378-5387. (b) Klikar, M.; Bureš, F.; Pytela, O.; Mikysek, T.; Padělková, Z.; Barsella, A.; Dorkenoo, K.; Achelle S. New. J. Chem. 
2013, 37, 4230-4240. (c) Wen, Y.; Wu, W.; Li, Y.; Li, Y.; Qin, T.; Tang, Y.; Wang, L.; Zhang, J. Org. Electron. 2016, 38, 61-68.

${ }^{9}$ (a) Kulhánek, J.; Bureš, F.; Opršal, J.; Kuznik, W.; Mikysek, T.; Růžička, A. Asian J. Org. Chem. 2013, 2, 422-431. (b) Castro, M. C. R.; Belsey, M.; Raposo, M. M. M. Dyes Pigm. 2016, 128, 89-95. (c) Tan, C.-J.; Yang, C.-S.; Sheng, Y.-C.; Amini, H. W.; Tsai, H.-H. G. J. Phys. Chem. C 2016, 120, 21272-21284. (d) Marco, A. B.; Mayorga Burrezo, P.; Mosteo, L.; Franco, S.; Garín, J.; Orduna, J.; Disodado, B. E.; Villacampa, B.; López-Navarrete, J. T.; Casado, J.; Andreu, R. RSC Adv. 2015, 5, 231-242. (e) Beverina, L.; Leclerc, A.; Zojer, E.; Pacher, P.; Barlow, S.; Ven Stryland, E. W.; Hagan, D. J.; Brédas, J.-L.; Marder, S. R. J. Am. Chem. Soc. 2005, 127, 7282-7283.

${ }^{10}$ (a) Achelle, S.; Baudequin, C. Targets Heterocycl. Syst. 2013, 17, 1-34. (b) Achelle, S.; Plé, N.; Turck, A. RSC Adv. 2011, 1, 364-388. (c) Achelle, S.; Rodríguez-López, J.; Katan, C.; Robin-le Guen, F. J. Phys. Chem. C 2016, 120, 26986-26995. (d) Achelle, S.; Barsella, A.; Baudequin, C.; Caro, B.; Robin-le Guen F. J. Org. Chem. 2012, 77, 4087-4096. (e) Kato, S.i.; Yamada, Y.; Hiyoshi, H.; Umezu, K.; Nakamura, Y. J. Org. Chem. 2015, 80, 9076-9090. (f) Cvejn, D.; Achelle, S.; Pytela, O.; Malval, J.-P.; Spangenberg, A.; Cabon, N.; Bureš, F.; Robin-le Guen, F. Dyes Pigm. 2016, 124, 101-109. (g) Schmitt, V.; Moschel, S. Detert, H. Eur. J. Org. Chem. 2013, 5655-5669.

${ }^{11}$ (a) Guo, M.; Li, M.; Dai, Y.; Shen, W.; Peng, J.; Zhu, C.; Lin, S. H.; He, R. RSC Adv. 2013, 3, 17515-15526. (b) Guo, M.-Y.; He, R.-X.; Dai, Y.-L.; Shen, W.; Li, M.; Zhu, C?-Y.; Lin, S.-H. J. Phys. Chem. C, 2012, 116, 9166-9179. (c) Chou, S-H.; Tsai, C.-H.; Wu, C.-C.; Kumar, D.; Wong, K.-T. Chem. Eur. J. 2014, 20, 16574-16582. (d) Lin, L.-Y.; Tsai, C.-H.; Wong, K.-T.; Huang, T.-W.; Wu, C.-C.; Chou, S.-H.; Lin, F.; Chen, S.-H.; Tsai, A.-I J. Mater. Chem. 2011, 21, 5950-5958. (e) Chiu, S.-W.; Lin, L.-Y.; Lin, H.-W.; Chen, Y.-H.; 
Huang, Z.-Y.; Lin, Y.-T.; Lin, F.; Liu, Y.-H.; Wong, K.-T. Chem. Commun. 2012, 48, 18571859.

12 (a) Alonso, M.; Miranda, C.; Martin, N.; Herradón, B. Phys. Chem. Chem. Phys. 2011, 13, 20564-20574. (b) Dong, W.; Wang, H.; Ge, Q.; Wang, L. Struct. Chem. 2007, 18, 593-597. (c) Bao, P.; Yu, Z.-H. J. Phys. Chem. A 2007, 111, 5304-5313. (d) Mandado, M.; Otero, N.; Mosquera, R. A. Tetrahedron 2006, 62, 12204-12210. (e) Wang, Y.; Wu, J. I. C.; Li, Q.; von Ragué Schleyer, P. Org. Lett. 2010, 12, 4824-4827

${ }^{13}$ Ortíz, A.; Insuasty, B.; Torres, M. R.; Herranz, M. Á.; Martín, N.; Viruela, R.; Ortí, E. Eur. J. Org. Chem. 2008, 99-10.

${ }^{14}$ Solanke, P.; Achelle, S.; Cabon N.; Pytela, O.; Barsella, A.; Caro, B.; Robin-le Guen, F.; Podlesný, J.; Klikar, M.; Bureš, F. Dyes Pigm. 2016, 134, 129-138.

${ }^{15}$ (a) Littke, A. F.; Fu, G. C. Angew. Chem. Int. Ed. 2002, 41, 4176-4211. (b) Maes, B. U. W.; Tapolcsanyi, P.; Meyers, C.; Matyus, M. Curr. Org. Chem. 2006, 10, 377-417. (c) Achelle, S.; Ramondenc, Y.; Marsais, F.; Plé, N. Eur. J. Org. Chem. 2008, 3129-3140.

${ }^{16}$ (a) Colombo, M.; Giglio, M.; Peretto, I. J. Heterocycl. Chem. 2008, 45, 1077-1081. (b) Rossi, R.; Bellina, F.; Lessi, M. Adv. Synth. Cat. 2012, 354, 1181-1255.

${ }^{17}$ Pan, H.; Gao, X.; Zhang, Y.; Prasad, P. N.; Reinhardt, B.; Kanna, R. Chem. Mater. 1995, 7, 816-821.

18 (a) Bureš, F.; Cvejn, D.; Melánová, K.; Beneš, L.; Svoboda, J.; Zima, V.; Pytela, O.; Mikysek, T.; Růžičková, Z.; Kityk, I. V.; Wojciechowski, A.; AlZayed, N. J. Mater. Chem. C 2016, 4, 468-478. (b) Kato, S.; Matsumoto, T.; Shigeiwa, M.; Gorohmaru, H.; Maeda, S.; Ishi-i, T.; Mataka, S. Chem. Eur. J. 2006, 12, 2303-2317. (c) Porrès, L.; Mongin, O.; Katan, C.; Charlot, M.; Pons, T.; Mertz, J.; Blanchard-Desce, M. Org. Lett. 2004, 6, 47-50.

${ }^{19}$ (a) Dehu, C.; Meyers, F.; Brédas, J. L. J. Am. Chem. Soc. 1993, 115, 6198-6206. 
${ }^{20}$ (a) Bird, C. W. Tetrahedron 1986, 42, 89-92. (b) Bird, C. W. Tetrahedron 1985, 41, 14091414. (c) Kotelevskii, S. I.; Prezhdo, O. V. Tetrahedron 2001, 57, 5715-5729; (d) Krygowski, T. M.; Szatylowicz, H.; Stasyuk, O. A.; Dominikowska, J.; Palusiak, M. Chem. Rev. 2014, 114,63836422 .

${ }^{21}$ (b) Solanke, P.; Bureš, F.; Pytela, O.; Klikar, M.; Mikysek, T.; Mager, L.; Barsella, A.; Růžičková, Z. Eur. J. Org. Chem. 2015, 5339-5349.

22 (a) Zhou, Y.; Ding, L.; Shi, K.; Dai, Y.-Z.; Ai, N.; Wang, J. Adv. Mater. 2012, 24, 957-961. (b) Monoharan, S.; Wu, J. J.; Anandan, S. Dyes Pigm. 2016, 133, 222-231.

${ }^{23}$ Yuan Chiu, K.; Xiang Su, T.; Hong Li, J.; Lin, T.-H.; Liou, G.-S.; Cheng, S.-H. J. Electroanal. Chem. 2005, 575, 95-101.

${ }^{24}$ The HOMO energy can be calculated from the onset oxidation potential $\left(\mathrm{E}_{\mathrm{ox}}\right)$ based on the reference energy level of ferrocene using the relationship of HOMO $=-\left[\mathrm{E}_{\mathrm{ox}}-\mathrm{E}_{\mathrm{Fc}}+4.8\right]$. The LUMO energy was obtained by addition of $\mathrm{E}_{0-0}(\Delta \mathrm{E})$ energy and HOMO.

${ }^{25}$ Bureš, F.; Čermáková, H.; Kulhánek, J.; Ludwig, M.; Kuznik, W.; Kityk, I. V.; Mikysek, T.; Růžička, A. Eur. J. Org. Chem. 2012, 529-538.

${ }^{26}$ Hadad, C.; Achelle, S.; García-Martinez, J. C.; Rodríguez-López J. J. Org. Chem. 2011, 76, 3837-3845.

${ }^{27}$ (a) Lartia, R.; Allain, C.; Bordeau, G.; Schmidt, F.; Fiorini-Debuisschert, C.; Charra, F.; Teulade-Fichou, M.-P. J. Org. Chem. 2008, 73, 1732-1744. (b) Katan, C.; Terenziani, F.; Mongin, O.; Werts M. H. W.; Porres, L.; Pons, T.; Mertz, J.; Tretiak, S.; Blanchard-Desce, M. J. Phys. Chem. A 2005, 109, 3024-3027.

${ }^{28}$ Reichardt, C. Chem. Rev. 1994, 94, 2319-2358.

${ }^{29}$ Ulrich, G.; Barsella, A.; Boeglin, A.; Niu, S.; Ziessel, R. ChemPhysChem 2014, 15, 2693 2700. 
${ }^{30}$ (a) Singer, K. D.; Garito, A. F. J. Phys. Chem. 1981, 75, 3572 -3580. (b) Levine, B. F.; Bethea, C. G. Appl. Phys. Lett. 1974, 24, 445 -447. (c) Ledoux, I.; Zyss, J. Chem. Phys. 1982, 73, 203 -213. (d) Thami, T.; Bassoul, P.; Petit, M. A.; Simon, J.; A. Fort, A.; Barzoukas, M.; Villaeys, A. J. Am. Chem. Soc. 1992, 114, 915 -921.

${ }^{31}$ Gaussian 09, Revision D.01, M. J. Frisch, G. W. Trucks, H. B. Schlegel, G. E. Scuseria, M. A. Robb, J. R. Cheeseman, G. Scalmani, V. Barone, B. Mennucci, G. A. Petersson, H. Nakatsuji, M. Caricato, X. Li, H. P. Hratchian, A. F. Izmaylov, J. Bloino, G. Zheng, J. L. Sonnenberg, M. Hada, M. Ehara, K. Toyota, R. Fukuda, J. Hasegawa, M. Ishida, T. Nakajima, Y. Honda, O. Kitao, H. Nakai, T. Vreven, J. A. Montgomery Jr., J. E. Peralta, F. Ogliaro, M. Bearpark, J. J. Heyd, E. Brothers, K. N. Kudin, V. N. Staroverov, R. Kobayashi, J. Normand, K . Raghavachari, A. Rendell, J. C. Burant, S. S. Iyengar, J. Tomasi, M. Cossi, N. Rega, J. M. Millam, M. K lene, J. E. Knox, J. B. Cross, V. Bakken, C. Adamo, J. Jaramillo, R. Gomperts, R. E. Stratmann, O. Yazyev, A. J. Austin, R. Cammi, C. Pomelli, J. W. Ochterski, R. L. Martin, K. Morokuma, V. G. Zakrzewski, G. A. Voth, P. Salvador, J. J. Dannenberg, S. Dapprich, A. D. Daniels, Ö. Fark as, J. B. Foresman, J. V. Ortiz, J. Cioslowski, D. J. Fox, Gaussian, Inc., Walling ford CT, 2013.

32 ArgusLab 4.0, Mark A. Thompson, Planaria Software LLC, Seattle, WA, http://www.arguslab.com.

${ }^{33}$ Li, J.; Jiang, Y.; Cheng, J.; Zhang, Y.; Su, H.; Lam, J. W. Y. Sung, H. H. Y.; Wong, K. S.; Kwok, H. S.; Tang, B. Z. Phys. Chem. Chem. Phys. 2015, 17, 1134-1141.

${ }^{34}$ Eaton, D. F. Pure Appl. Chem. 1988, 60, 1107-1114.

${ }^{35}$ Liu C.; Ni, Q.; Qiu J. Eur. J. Org. Chem. 2011, 3009-3015.

${ }^{36}$ Li, Z. H.; Wong, M. S.; Tao, Y.; D'Iorio, M. J. Org. Chem. 2004, 69, 921-927. 
37 Scrascia, A.; De Marco L.; Laricchia, S.; Picca, R. A.; Carlucci, C.; Fabiano, E.; Capodilupo, A. L.; Della Sala, F.; Gigli, G.; Ciccarella, G. J. Mater. Chem A 2013, 1, 1190911921.

${ }^{38}$ Abers, H. M. H. G.; Hendrickx, L. J. D.; van Tol, R. J. P.; Hausmann, J.; Perrakis, A, Ovaa H. J. Med. Chem. 2011, 54, 4619-4626.

${ }^{39}$ Zeng, S.; Yin, L.; Ji, C.; Jiang, X.; Li, K.; Li, Y.; Wang, Y. Chem. Commun. 2012, 48, 10627-10629.

${ }^{40}$ Sun, M.; Bo, Z. J. Polym. Sci. Polym. Chem. 2006, 45, 111-124. 